\title{
Diagnosis, Therapy and Follow-up of Diabetes Mellitus in Children and Adolescents
}

\section{Authors}

Andreas Neu ${ }^{1}$, Jutta Bürger-Büsing ${ }^{2}$, Thomas Danne ${ }^{3}$, Axel Dost ${ }^{4}$, Martin Holder ${ }^{5}$, Reinhard W. Holl ${ }^{6}$, Paul-Martin Holterhus $^{7}$, Thomas Kapellen ${ }^{8}$, Beate Karges ${ }^{9}$, Olga Kordonouri ${ }^{3}$, Karin Lange ${ }^{10}$, Susanne Müller ${ }^{11}$, Klemens Raile², Roland Schweizer ${ }^{1}$, Simone von Sengbusch ${ }^{13}$, Rainer Stachow ${ }^{14}$, Verena Wagner ${ }^{15}$, Susanna Wiegand ${ }^{12}$, Ralph Ziegler ${ }^{16}$

\section{Affiliations}

1 Universitätsklinikum Tübingen, Klinik für Kinder- und Jugendmedizin, Germany global for all affiliations, Germany

2 Bund diabetischer Kinder und Jugendlicher e.V., Diabeteszentrum, Kaiserslautern, Germany

3 Kinder- und Jugendkrankenhaus Auf der Bult, Hannover

4 Universitätsklinikum Jena, Klinik für Kinder- und Jugendmedizin, Germany

5 Klinikum Stuttgart, Olgahospital, Germany

6 Institut für Epidemiologie und medizinische Biometrie, ZIBMT, Universität Ulm, Germany

7 Universitätsklinikum Schleswig-Holstein, Campus Kiel, Klinik für Allgemeine Pädiatrie, Germany

8 Universitätsklinikum Leipzig, Klinik und Poliklinik für Kinder- und Jugendmedizin, Germany

9 RWTH Aachen, Universitätsklinikum, Sektion Endokrinologie und Diabetologie, Germany

10 Medizinische Hochschule Hannover, Medizinische Psychologie, Germany

11 Praxis für Ernährungsberatung, Ennepetal, Germany

12 Charité, Universitätsmedizin Berlin, Virchow-Klinikum, Germany

13 Universitätsklinikum Schleswig-Holstein, Campus Lübeck, Klinik für Kinder- und Jugendmedizin, Germany

14 Fachklinik Sylt für Kinder und Jugendliche, Westerland, Germany

15 Gemeinschaftspraxis für Kinder- und Jugendmedizin, Rostock, Germany

16 Praxis für Kinder- und Jugendmedizin, Diabetologische Schwerpunktpraxis, Münster, Germany
Bibliography

DOI https://doi.org/10.1055/a-0869-0210

Published online: 29.4.2019

Exp Clin Endocrinol Diabetes 2019; 127: 341-352

(c) J. A. Barth Verlag in Georg Thieme Verlag KG Stuttgart .

New York

ISSN 0947-7349

\section{Correspondence}

Prof. Dr. Andreas Neu

Universitätsklinikum Tübingen,

Klinik für Kinder- und

Jugendmedizin,

Hoppe-Seyler-Straße 1,

72076 Tübingen,

Germany

andreas.neu@med.uni-tuebingen.de

\section{Supplementary Material Reference List}

Online content viewable at https://doi.org/10.1055/a-0869-0210

\section{INDEX OF ABBREVIATIONS}

$\begin{array}{ll}\text { Abbreviation } & \begin{array}{l}\text { Description (German designation, if } \\ \text { applicable) }\end{array} \\ \mu g & \text { Microgram } \\ \text { ABCC8 gene } & \text { Gene localization for the sulfonylurea receptor 1 } \\ \text { ACE } & \text { Angiotensin converting enzyme } \\ \text { ACR } & \text { Albumin-creatinine ratio } \\ \text { ADA } & \text { American Diabetes Association }\end{array}$

Attention deficit hyperactivity disorder Albumin excretion rate German Association for Obesity in Childhood and Adolescence (Arbeitsgemeinschaft Adipositas) German Pediatric Diabetology Association (Arbeitsgemeinschaft für pädiatrische Diabetologie) 


\begin{tabular}{|c|c|c|c|}
\hline $\begin{array}{l}\text { AHCPR } \\
\text { AlHA }\end{array}$ & $\begin{array}{l}\text { Agency for Health Care Policy and Research } \\
\text { Autoimmune hemolytic anemia }\end{array}$ & EASD & $\begin{array}{l}\text { European Association for the Study of } \\
\text { Diabetes }\end{array}$ \\
\hline$A b$ & Antibodies & EDIC & Trial Epidemiology of Diabetes Interven- \\
\hline ALAT & Alanine aminotransferase $=$ liver enzyme & & tions and Complications Trial = successor to \\
\hline \multirow[t]{2}{*}{ APS } & German Association for Pediatric Metabolic & & the DCC trial \\
\hline & $\begin{array}{l}\text { Disorders (Arbeitsgemeinschaft für } \\
\text { pädiatrische Stoffwechselstörungen) }\end{array}$ & EIF2AK3 gene & $\begin{array}{l}\text { Gene site for mutations which lead to a } \\
\text { genetic syndrome with diabetes }\end{array}$ \\
\hline APS & Autoimmune polyglandular syndrome & $\mathrm{EC}$ & Evidence class (methodological quality of a \\
\hline AT1 & blocker Angiotensin type 1 receptor blocker & & study according to criteria from evidence- \\
\hline AWMF & Scientific Medical Society Board & & based medicine) \\
\hline BABYDIAB & German BabyDiab study & ECG & Electrocardiogram \\
\hline BAR & $\begin{array}{l}\text { German Federal Association for Rehabilita- } \\
\text { tion }\end{array}$ & $\begin{array}{l}\text { EMA } \\
\text { ENDIT }\end{array}$ & $\begin{array}{l}\text { European Medicines Agency } \\
\text { European Nicotinamide Intervention Trial }\end{array}$ \\
\hline BdKJ & $\begin{array}{l}\text { German Diabetic Children and Adolescents' } \\
\text { Association }\end{array}$ & $\begin{array}{l}\text { ES } \\
\text { ethn. }\end{array}$ & $\begin{array}{l}\text { Educational support } \\
\text { Ethnic }\end{array}$ \\
\hline BG & Blood glucose & fam & Family \\
\hline BMI & Body mass index & FES & Family Environment Scale = scale for \\
\hline BMI-SDS & $\begin{array}{l}\text { Body mass index standard deviation score } \\
\text { (standardized body mass index) }\end{array}$ & & $\begin{array}{l}\text { assessment of the social characteristics and } \\
\text { environment of families }\end{array}$ \\
\hline BS & Blood sugar & FOXP3 gene & Gene site for mutations which lead to \\
\hline CFRD & Cystic fibrosis-related diabetes & & genetic syndromes with diabetes \\
\hline CGM & Continuous glucose monitoring & FST-D & Family system therapy for patients with \\
\hline CK & Creatine kinase & & diabetes \\
\hline C-peptide & Connecting peptide $=$ part of proinsulin & fT3 & Free triiodothyronine \\
\hline \multirow[t]{2}{*}{ CSII } & Continuous subcutaneous insulin injec- & fT4 & Free thyroxine \\
\hline & tion = insulin pump & $g$ & Grams \\
\hline CT & Computed tomography & GAD & Glutamate decarboxylase \\
\hline \multirow[t]{2}{*}{ DAG } & German Obesity Society (Deutsche & GCK & Glucokinase \\
\hline & Adipositas Gesellschaft) & $\mathrm{h}$ & Hour \\
\hline DAISY & Diabetes Autoimmunity Study of the Young & $\mathrm{HbA1c}$ & Glycolized hemoglobin \\
\hline \multirow[t]{2}{*}{ DCC } & Trial Diabetes Control and Complications & $\mathrm{HDL}$ & High-density lipoprotein \\
\hline & Trial & HHS & Hyperosmolar hyperglycemic state \\
\hline \multirow[t]{2}{*}{ DDG } & German Diabetes Society (Deutsche & HLA & Human leucocyte antigen \\
\hline & Diabetes Gesellschaft) & HNF & Hepatocyte nuclear factor \\
\hline DEND & Diabetes epilepsy and neurological delay & HTA & Health technology assessment = systematic \\
\hline DENIS & German Nicotinamide Intervention Study & & assessment of medical technologies, \\
\hline DEPS-R & Diabetes Eating Problem Survey-Revised & & procedures, and aids, but also organization \\
\hline DGE & $\begin{array}{l}\text { German Society for Nutrition (Deutsche } \\
\text { Gesellschaft für Ernährung) }\end{array}$ & & $\begin{array}{l}\text { structures in which medical services are } \\
\text { provided }\end{array}$ \\
\hline \multirow[t]{2}{*}{ DGEM } & German Society for Nutritional Medicine & IU & International unit(s) \\
\hline & (Deutsche Gesellschaft für Ernährungsmedizin) & i.m. & Intramuscular \\
\hline \multirow[t]{5}{*}{ DGKJP } & German Society for Child and Adolescent & i.v. & Intravenous \\
\hline & Psychiatry, Psychomatics and Psychothera- & IA2 & Tyrosine phosphatase IA2 antibodies \\
\hline & py (Deutsche Gesellschaft für Kinder- und & IAA & Insulin autoantibodies \\
\hline & Jugend- psychiatrie, Psychosomatik und & ICA & Islet cell antibodies \\
\hline & Psychotherapie) & ICT & Intensified conventional therapy \\
\hline diab & Diabetic & $\lg A$ & Immunoglobulin A \\
\hline Diabetes & DE Diabetes-dedicated organization & $\lg G$ & Immunoglobulin G \\
\hline DIAMYD & 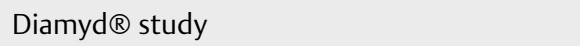 & INS & Insulin (gene) \\
\hline DIPP & Diabetes Prediction and Prevention Project & IPEX syndrome & Immunodysregulation polyendocrinopathy \\
\hline DKA & Diabetic ketoacidosis & & enteropathy X-linked syndrome und \\
\hline dl & Deciliters & & Immundysregulation) \\
\hline DNSG & Diabetes and Nutrition Study Group & IPF-1gene & Insulin promotor factor 1 gene = gene site \\
\hline DPT-1 & Diabetes Prevention Trial-Type 1 & & for mutations which lead to MODY- 4 \\
\hline DPV & Diabetes Patient Administration & & diabetes \\
\hline
\end{tabular}




\begin{tabular}{|c|c|c|c|}
\hline $\begin{array}{l}\text { IRMA } \\
\text { ISPAD }\end{array}$ & $\begin{array}{l}\text { Intraretinal microvascular anomaly } \\
\text { International Society for Pediatric and } \\
\text { Adolescent Diabetes }\end{array}$ & RR & $\begin{array}{l}\text { Riva Rocci=arterial pressure, measured acc. } \\
\text { to the Riva Rocci method } \\
\text { subcutaneous }\end{array}$ \\
\hline ITP & Immune thrombocytopenic purpura & SC & Standard care \\
\hline$y$ & Years & SEARCH & Search for diabetes in the youth study \\
\hline n.s. & Not specified & SGB & German Penal Code (Strafgesetzbuch) \\
\hline kcal & Kilocalories & SIGN & Scottish Intercollegiate Guidelines Network \\
\hline KCNJ11 & $\begin{array}{l}\text { Inward-rectifier potassium channel, } \\
\text { subfamily J, member } 11\end{array}$ & $\begin{array}{l}\text { sign. } \\
\text { SSRI }\end{array}$ & $\begin{array}{l}\text { significant } \\
\text { Selective serotonin reuptake inhibitor }\end{array}$ \\
\hline $\mathrm{kg}$ & Kilograms & STIKO & Standing Vaccination Commission of the \\
\hline BW & Body weight & & Federal Republic of Germany (Ständige \\
\hline Kir6.2 & Gene localization for KCNJ11 & & Impfkommission der Bundesrepublik \\
\hline KJHG & $\begin{array}{l}\text { German Child and Youth Welfare Law } \\
\text { (Kinder- und Jugendhilfegesetz) }\end{array}$ & SUR 1 & $\begin{array}{l}\text { Deutschland) } \\
\text { Sulfonylurea receptor } 1\end{array}$ \\
\hline I & Liters & $\mathrm{T} 3$ & Triiodothyronine \\
\hline LDL & Low-density lipoprotein & T4 & Thyroxine \\
\hline LGS & Low-glucose suspend & dly & daily \\
\hline$m^{2}$ & Square meters & $\mathrm{Tg}-\mathrm{Ab}$ & Thyroglobulin antibodies \\
\hline $\max$. & Maximum & TNDM & Transient neonatal diabetes mellitus \\
\hline $\mathrm{mg}$ & Milligrams & $\mathrm{TPO}-\mathrm{Ab}$ & Thyroid peroxidase antibodies \\
\hline Micro & Microalbuminuria & TRAK & TSH receptor autoantibodies \\
\hline $\begin{array}{l}\min . \\
\text { avg. }\end{array}$ & $\begin{array}{l}\text { Minimum } \\
\text { average }\end{array}$ & TRIGR & $\begin{array}{l}\text { Trial to Reduce IDDM in the Genetically at } \\
\text { the Risk }\end{array}$ \\
\hline MJ & Megajoules & TSH & Thyroid-stimulating hormone/thyrotropin \\
\hline $\mathrm{ml}$ & Milliliters & $\mathrm{U}$ & Unit \\
\hline $\mathrm{mm}$ & Millimeters & UK & United Kingdom \\
\hline $\mathrm{mmHg}$ & $\begin{array}{l}\text { Millimeter of mercury = unit of measure for } \\
\text { blood pressure }\end{array}$ & $\begin{array}{l}\text { esp. } \\
\text { vs. }\end{array}$ & $\begin{array}{l}\text { especially } \\
\text { versus }\end{array}$ \\
\hline $\mathrm{mmol}$ & Millimol & WHO & World Health Organization \\
\hline Mo & Month(s) & CNS & Central nervous system \\
\hline MODY & Maturity onset diabetes of the young = mo- & ZnT8 & Zinc transporter 8 \\
\hline
\end{tabular}

$\begin{array}{lll}\text { MRI } & \text { Magnetic resonance imaging } & 1 \text { Matter and Background }\end{array}$

$\mathrm{NaCl} \quad$ Sodium chloride The improvement in care for children and adolescents with diabeNDM Neonatal diabetes mellitus

In order to take the particularities of a chronic childhood and youth disease into account, specific aspects of this stage of life must be considered.

These recommendations apply to all professions involved in the management and support of children and adolescents with diabetes and their families, as well as superordinate organizations (e.g., health insurance providers) that deal with the disease.

According to the standards by federal state health ministers and the common practice of many clinics, the age up to which these pediatric guidelines should apply is defined as 18 years of age. These guidelines can also apply to young adults, however.

\section{Epidemiology and Types of Diabetes in Childhood and Adolescence}

\subsection{Type 1 diabetes}

Type 1 diabetes remains the most common metabolic childhood disease. According to current estimates, between 15,600 and 
17,400 children up to 14 years of age with type 1 diabetes live in Germany [Rosenbauer et al. 2013]. In the age group of 0 to 19 years, between 21,000 and 24,000 children and adolescents were affected at the start of the millennium [Rosenbauer et al. 2002]. This figure is currently estimated to be around 30,000 to 32,000 [Rosenbauer et al. 2012].

In the 1990s, the average annual incidence rate was reported as between 12.9 (95\% confidence interval [Cl] 12.4-13.4) and 14.2 (95\% Cl 12.9-15.5) per 100,000 children aged 0 to 14 years and 17.0 (95\% Cl 15.2-18.8) per 100,000 aged 0 to 19 years [Neu et al. 2001; Rosenbauer et al. 2002b; Neu et al. 2008]. The incidence rate rises by 3-4\% annually [Ehehalt et al. 2008; Neu et al. 2013]. Compared to the early 1990 s, the incidence rate for 0 - to 14 -year-olds has now doubled and is currently $22.9 \%$ (95\% Cl 22.2-23.6). The rise in incidence can be observed particularly among younger age groups.

\subsection{Type 2 diabetes}

In parallel to the rise in prevalence of overweight and obesity in children and adolescents [Kurth et al. 2007; Kromeyer-Hauschild et al. 2001], the frequency of type 2 diabetes has increased in this age group. Initial population-based estimates of type 2 diabetes in children and adolescents in 2002 yielded an incidence rate of 1.57 per 100,000 (95\% Cl 0.98-2.42) [Rosenbauer et al. 2003]. Investigations in Baden-Württemberg from 2004 indicated that among 0 - to 20 -year-olds in Germany, type 2 diabetes exhibits a prevalence of 2.3 per 100,000 [Neu et al. 2005]. The current incidence is estimated at 200 new cases per year among 12- to 19-year-olds [Danne 2014].

\section{Risk Factors, Prevention, and Early Detection of Diabetes}

\subsection{Type 1 diabetes}

The diagnosis of type 1 diabetes is based on clinical symptoms and blood glucose testing. In cases of doubt, further parameters for diagnosis clarification may be employed. These include: 1) autoantibodies associated with diabetes (ICA, GAD 65, IA2, IAA, ZnT8), 2) oral glucose tolerance test, and 3) HbA1c determination [International Society for Pediatric and Adolescent Diabetes (ISPAD) 2014; Ehehalt et al. 2010].

Among all children and adolescents under 15 years of age with type 1 diabetes, $10-15 \%$ have first-degree relatives with diabetes and thus a positive familial medical history [Rosenbauer et al. 2003; Scottish Study Group for the Care of the Young Diabetic 2001]. The risk of developing diabetes is three times higher for a child with a diabetic father than for a child with a diabetic mother [Gale and Gillespie (2001)]. While antibodies and other markers allow prediction and risk calculation with regard to the development of diabetes, there is a lack of effective strategies that could prevent diabetes onset [Rosenbloom et al. 2000; Australasian Paediatric Endocrine Group et al. 2005].

General screening for type 1 diabetes should therefore not be carried out in the general population or in high-risk groups among children and adolescents [Australasian Paediatric Endocrine Group et al. 2005b].

\subsection{Type 2 diabetes}

An oral glucose tolerance test for early detection of type 2 diabetes should be carried out as of the 10 th year of age in cases of overweight (BMI>90th percentile) and the presence of at least two of the following risk factors:

- type 2 diabetes among first- or second-degree relatives

- belonging to a higher-risk ethnic group (e. g., East Asian, African American, Hispanic)

- extreme obesity (BMI>99.5th percentile)

- signs of insulin resistance or associated changes (arterial hypertension, dyslipidemia, elevated transaminases, polycystic ovary syndrome, acanthosis nigricans)

[Arbeitsgemeinschaft Adipositas im Kindes- und Jugendalter (AGA) (2008)]

\section{Treatment of Type 1 Diabetes}

\subsection{Start of the therapy}

Insulin therapy should be introduced immediately upon diagnosis of type 1 diabetes, as a child's metabolism can rapidly deteriorate. A diabetes team experienced in working with children should be consulted as soon as possible [Bangstad et al. 2007].

\subsection{Therapeutic objectives}

Initial treatment and long-term care should be carried out continuously from the 1st year through to the 18th year of age - and in certain cases until the 21 st year - by a diabetes team experienced in working with children. The specialized care is proven to contribute to a decrease in time spent in the hospital and hospital readmissions, a lower HbA1c value with better disease management and fewer complications [Cadario et al. 2009; Pihoker et al. 2014; Australasian Paediatric Endocrine Group et al. 2005].

The treatment of type 1 diabetes by a care team should include:

- insulin therapy

- individual self-monitoring of metabolism

- structured learning program according to age

- psychosocial care for the affected families

The following medical aims are at the forefront of care for pediatric patients with diabetes mellitus [Danne et al. 2014]: avoidance of acute metabolicdecompensation, prevention of microvascular and macrovascular complications related to diabetes, and normal physical development (growth, weight gain, onset of puberty). The psychosocial development of patients should be impaired as little as possible by diabetes and its treatment, while integration and inclusion in kindergarten, grade school, and vocational training should be ensured.

Individual therapy objectives should be formulated with the child or adolescent and his/her family (HbA1c value, target blood glucose range, changes in behavior in the event of risk-prone lifestyles, efforts to integrate, etc.).

The targeted $\mathrm{HbA} 1 \mathrm{c}$ value should be $<7.5 \%$, without hypoglycemia occurring. Fluctuations in blood glucose should be kept as minimal as possible [Bangstad et al. 2007; Clarke et al. 2008a]. Recommended values for blood glucose are given in $>$ Table. 1 according to [Rewers et al. 2007]. 
- Table. 1 Recommended orientation values for blood glucose monitoring1.

\begin{tabular}{|c|c|c|c|c|}
\hline $\begin{array}{l}\text { Blood glucose (BG) monitoring: clinical- } \\
\text { chemical evaluation }\end{array}$ & healthy & good & $\begin{array}{l}\text { moderate } \\
\text { (measures recommended) }\end{array}$ & $\begin{array}{l}\text { poor } \\
\text { (measures required) }\end{array}$ \\
\hline preprandial or fasting BG (mmol/l or mg/dl) & $\begin{array}{l}3.6-5.6 \\
65-100\end{array}$ & $\begin{array}{l}5-82 \\
90-145\end{array}$ & $\begin{array}{l}>8 \\
>145\end{array}$ & $\begin{array}{l}>9 \\
>162\end{array}$ \\
\hline Postprandial BG (mmol/l or mg/dl) & $\begin{array}{l}4.5-7.0 \\
80-126\end{array}$ & $\begin{array}{l}5-10 \\
90-180\end{array}$ & $\begin{array}{l}10-14 \\
180-250\end{array}$ & $\begin{array}{l}>14 \\
>250\end{array}$ \\
\hline Nightly $\mathrm{BG}^{3}$ (mmol/l or mg/dl) & $\begin{array}{l}3.6-5.6 \\
65-100\end{array}$ & $\begin{array}{l}4.5-9 \\
80-162\end{array}$ & $\begin{array}{l}<4.2 \text { or }>9 \\
<75 \text { or }>162\end{array}$ & $\begin{array}{l}<4.0 \text { or }>11<70 \\
\text { or }>200\end{array}$ \\
\hline $\begin{array}{l}\text { HbA1c value (\%) (standardized measurement } \\
\text { acc. to DCC trial guidelines) }\end{array}$ & $<6.05$ & $<7.5$ & $7.5-9.0$ & $>9.0$ \\
\hline \multicolumn{5}{|c|}{$\begin{array}{l}1 \text { These general orientation values have to be adapted to the individual circumstances of a given patient. Deviating values are especially typical for } \\
\text { small children, patients with severe hypoglycemia, or patients that are not capable of recognizing hypoglycemia [Cranston et al. } 1994 \text { ]; }{ }^{2} \text { If fasting } \\
\text { blood glucose is under } 72 \mathrm{mg} / \mathrm{dl} \text { (under } 4 \mathrm{mmol} / \mathrm{l}) \text {, the possibility of hypoglycemia having occurred previously at night should be considered [Holl et al. } \\
\text { 1992]; }{ }^{3} \text { These figures are based on clinical studies, however, there are no strict, evidence-based recommendations. }\end{array}$} \\
\hline
\end{tabular}

The average frequency of blood glucose testing should be between 5 and 6 times a day; however, it may be considerably higher in particular cases [Ziegler et al. 2011].

\subsection{Continuous treatment of type 1 diabetes}

In order to ensure a metabolism that is as close to normoglycemic levels as possible as well as unimpeded psychosocial development, the continuity of treatment for diabetes mellitus is a decisive factor over the course of time and with regard to the different life and development phases of a child and adolescent with diabetes.

\section{Care for children in kindergartens and schools}

Children with diabetes should receive care in mainstream kindergartens/elementary schools [Hellems and Clarke 2007].

An individual plan should be created for the institution (e. g., kindergarten, school, after-school care) in terms of the frequency and intervention limits of blood sugar/glucose measurement, insulin administration (mode, time, dosage calculation), defined mealtimes, symptoms, and management of hypoglycemia and hyperglycemia [American Diabetes Association (ADA) (2015)].

Care during transition into young adulthood

The transition period from pediatric to adult diabetic care applies to young people with diabetes aged from 16 to 21 years in a life period characterized by general radical changes and requires special support (transition counseling, structured transition) [Nakhla et al. 2008; Australasian Paediatric Endocrine Group et al. 2005a; Court et al., (2008)].

Care in the event of illness and avoidance of associated risks

In case of severe illness and perioperatively, diabetic children should be referred to a center with appropriate experience and proper resources. The pediatric diabetologist should be involved [Brink et al. 2007].

Under no circumstances insulin should be forgone in the event of low glucose levels or when food is being refused. Intake of carbohydrates is necessary to avoid substrate deficiency and ketone body development.

Children with diabetes mellitus should be vaccinated according to STIKO recommendations.
Diabetes treatment with regard to physical activity/sports

Regular athletic activities improve metabolic control. Regular swimming is proven to significantly decrease the $\mathrm{HbA} 1 \mathrm{c}$ value [Sideravicite et al. 2006].

Because blood sugar levels drop as a result of energy consumption during sports, the risk of hypoglycemia rises. The strongest predictor of hypoglycemia is the initial glucose value, which should be at least $120 \mathrm{mg} / \mathrm{dl}(6.6 \mathrm{mmol} / \mathrm{l})$ [Tansey et al. 2006].

\subsection{Insulin treatment}

The standard treatment for pediatric patients affected by type 1 diabetes should be intensified insulin therapy.

Every insulin therapy should be carried out as part of comprehensive diabetes care and with the support of the family.

The insulin therapy should be individually tailored to each child [Diabetes Control and Complications Trial Research Group 1995; White et al. 2008; Nathan et al. 2005]; Musen et al. [2008].

For pediatric patients, human insulin or insulin analogues should be used [Bangstad et al. 2007; Danne et al. 2005; Mortensen et al. [2000; Deeb et al. 2001; Plank et al. 2005; Simpson et al. 2007].

For intravenous insulin treatment, normal insulin should be employed.

Short-acting insulins and insulin analogues (prandial substitution)

Short-acting human insulin and fast-acting insulin analogues display different results in children regarding onset and duration of effect, and can be used flexibly for prandial substitution in children depending on the situation [Danne et al. 2005; Mortensen et al. 2000].

For insulin pump therapy, short-acting insulin analogues should be used.

Long-acting insulins and insulin analogues (basal substitution)

Both NPH insulin and long-acting insulin analogues can serve individually as a basal insulin substitution for children [Danne et al. 2003; Danne et al. 2008; Thisted et al. 2006; Robertson et al. 2007; Danne et al. 2013; Thalange et al. 2015]. 
Insulin pump therapy

For the following indications, an insulin pump therapy should be considered:

- small children, particularly newborns, infants and pre-school children,

- children and adolescents with a notable rise in blood sugar in the early hours of the morning (dawn phenomenon),

- severe hypoglycemia, recurring and night-time hypoglycemia (despite intensified conventional therapy =ICT),

- HbA1c value outside of the target range (despite ICT),

- beginning microvascular or macrovascular complications,

- restricted quality of life through insulin treatment so far,

- children with excessive fear of needles,

- pregnant adolescents (in the event of planned pregnancy, ideally preconceptionally),

- competitive athletes,

- significant fluctuations in blood sugar irrespective of HbA1c value (despite ICT)

[Phillip et al. 2007].

Continuous glucose measurement (CGM), sensor-assisted insulin therapy, and sensor-assisted insulin pump therapy

CGM systems can be used with ICT (sensor-assisted insulin therapy]). Some CGM systems can be used together with an insulin pump, or the insulin pump can serve as a monitor for CGM data. This combination (CSII + CGM) is now designated as sensor-assisted insulin pump therapy. Furthermore, there is the possibility of stopping the basal rate if the tissue glucose reaches a critical limit (sensor-assisted insulin pump therapy + low-glucose suspend [LGS]).

CGM should be employed in children and adolescents with type

1 diabetes and insulin pump therapy

- to decrease the rate of hypoglycemia (frequency, duration, depth) or

- in case of recurring nightly hypoglycemia or

- in case of lack of perception of hypoglycemia or

- in case of severe hypoglycemia having taken place

[Bergenstal et al. 2013; Ly et al. 2013; Maahs et al. 2014].

CGM should be considered and, if applicable, employed in pediatric patients with type 1 diabetes if the $\mathrm{HbA} 1 \mathrm{c}$ target value is not reached after the exhaustion of other metabolism-optimizing and educational measures [Battelino et al. 2012; Bergenstal et al. 2010].

\subsection{Dietary recommendations}

The dietary advice included in patient education is an important part of the comprehensive therapy plan. The dietary advice for children and adolescents with diabetes should cover the following components:

- explanation of the impact that carbohydrates, fats, and proteins have on one's blood sugar,

- reinforcement of healthy diets within the family and in public institutions: regular, balanced mealtimes with snacks in between (fruit, vegetables, raw food), prevention of eating disorders (particularly binge-eating, i. e. uncontrolled hunger attacks), and prevention of overweight,
- sufficient energy for age-related growth and age-appropriate development,

- aiming for a normal BMI, which includes regular bodily activity,

- balance between energy intake and

- consumption in accordance with the insulin activity profiles,

- diet in the event of illness and sports,

- reduction of risk of cardiovascular diseases,

- consideration of cultural eating habits.

modified according to [Smart et al. 2014]).

The dietary advice should be given by dietary specialists (diet assistants/ecotrophologists) with in-depth knowledge of children's and adolescents' diets and insulin treatment [Smart et al. 2014; Craig et al. 2011].

Dietary recommendations should include all dietary components and the proportion they make up of one's daily energy intake [Deutsche Gesellschaft für Ernährung DGE et al, Österreichische Gesellschaft für Ernährung ÖGE, Schweizerische Gesellschaft für Ernährungsforschung SGE(2015].

\subsection{Diabetes education}

The patient education is an integral component of the therapy. Without appropriately coordinated medical treatment, it is not successful [Bloomgarden et al., (1987); deWeerdt et al., (1991)].

Children, adolescents, and their parents or other primary caregivers should have continuous access to qualified education offers upon diagnosis [Craig et al. 2011; Bundesärztekammer (BÄK), (2012); Canadian Diabetes Association Clinical Practice Guidelines Expert Committee 2013; Kulzer et al. 2013a; Martin et al. 2012; Lange et al. 2014a; Haas et al. 2014].

Supervisors in institutions (e. g., teaching staff at school and caretakers in kindergartens, child care facilities, nurseries, or group homes) should be offered educational sessions [Hellems and Clarke 2007; Lange et al. 2012; Clarke et al. 2013].

The educational sessions should be carried out by an interdisciplinary diabetes team with sufficient knowledge of the age-specific needs, opportunities and requirements of current diabetes treatments for patients and their families.

The educational component should be conducted by all team members, and jointly formulated treatment concepts and aims should ensue [Swift et al. 2010; Lange et al. 2014a; Cameron et al. 2013].

The learning process should be accompanied by evaluated educational documents that are oriented toward the cognitive development and needs of children and adolescents. The same applies to the educational materials for parents, including the childrearing tasks and age-specific diabetes treatment of their children [Martin et al. 2012; Lange et al. 2012; Lange et al. 2014a].

Diabetes education is a continuous process that is successful only through repeated, need-based offers (at least once every 2 years) during long-term care. New treatment concepts, for example initiation of insulin pump treatment or continuous glucose measurement (CGM), and new stages of life (e. g., starting school) should be accompanied with extra educational sessions. Further conditions (e.g., celiac disease or ADHD) or acute complications (e. g., DKA, severe hypoglycemia) or mental health problems re- 
quire personalized schooling [Jacobson et al. 1997; Haas et al. 2014; Lange et al. 2014b; Delamater et al. 2014].

\subsection{Rehabilitation}

Inpatient rehabilitation can be carried out

- if a patient's ability to handle their diabetes proves deficient over a longer period

- in the event of secondary diseases related to diabetes or current threat of such diseases,

- after stationary primary treatment of newly diagnosed diabetes mellitus, in the event that no initial schooling can be carried out due to lack of nearby options (follow-on care),

- in the event of long-term, insufficient metabolic control under outpatient care conditions, e. g., recurring hypoglycemia or ketoacidosis,

- in case of considerable negative impact on age-appropriate scope of activities and participation in day-to-day life, e. g., missing many days of school due to illness

(§ 4 SGB 9; Bundesarbeitsgemeinschaft für Rehabilitation)

[Bundesarbeitsgemeinschaft für Rehabilitation BAR (2008); Fröhlich et al. 2008; Deutsche Gesellschaft für pädiatrische Rehabilitation und Prävention, 2007; Stachow et al. 2001].

\section{Psychological and Social Risks, Comorbidities and Interventions}

When diabetes is diagnosed, the psychosocial situation of the family should be recorded as part of medical history. The families should receive psychosocial counseling. An interdisciplinary team should offer their therapeutic aid to tackle diabetes in accordance with the patient's needs. The mental health situation of the parents and other caregivers should be taken into account [Hürter 1991; Sundelin et al. 1996; Delamater et al. 1990; Craig et al. 2011; Delamater et al. 2014; Forsander et al. 1998; Sullivan-Bolyai et al., (2011); Forsander et al. 2000; Zenlea et al. 2014].

The current psychosocial situation and, if applicable, stressful life events should be continuously recorded during long-term care (intellectual, academic, emotional, and social development) and should be considered during therapy.

Therefore, social workers and psychologists with diabetes-specific expertise should constitute a fixed component in an interdisciplinary diabetes team [Silverstein et al. 2005; Craig et al. 2011; de Wit et al. 2008; Delamater et al. 2014; Kulzer et al. 2013a; Kulzer et al. 2013b; Hilliard et al. 2011; Haas et al. 2014; de Wit et al., 2012].

Particularly with adolescents, signs of eating disorders or affective disorders (e. g., anxiety, depression, adjustment disorders) should be noted and, if applicable a specialist diagnosis should be carried out and early intervention undertaken.

In the event of a psychiatrically relevant disorder, child and youth psychiatrists or psychological psychotherapists should be involved, in order to initiate co-treatment as necessary. A treatment coordinated between a psychiatrist and a diabetes team should be aimed for [Northam et al. 2005; Lawrence et al. 2006; Delamater et al. 2014; Kulzer et al. 2013a; Kulzer et al. 2013b; Young et al. 2013].
Children and adolescents with diabetes display an increased risk of developing information-processing and learning disorders. Those especially affected are children with early-onset diabetes, severe hypoglycemia, and chronic hyperglycemia at an early age.

Therefore, the academic performance of children with an increased risk (diabetes diagnosis at under age 5, severe hypoglycemia / chronic hyperglycemia) should be recorded. With regard to learning difficulties, they, as all children, should be neurophysiologically and psychologically examined in order to clarify cases of learning disabilities and, if necessary, offer support [Delamater et al. 2014].

\section{Acute Complications}

\subsection{Diabetic ketoacidosis}

Diabetic ketoacidosis is a potentially life-threatening disease. It should be immediately treated in a specialized facility by an experienced pediatric diabetes team. A written treatment plan should be available for the treatment of diabetic ketoacidosis in children and adolescents [Australasian Paediatric Endocrine Group et al. 2005; Glaser et al. 2006; Fiordalisi et al. 2007].

The biochemical criteria for ketoacidosis include the following:

- $\mathrm{pH}<7.3$,

- bicarbonate $<15 \mathrm{mmol} / \mathrm{l}$,

- hyperglycemia >11 mmol/l, > $200 \mathrm{mg} / \mathrm{dl}$,

- ketonuria and ketone detection in the serum.

There are three degrees of severity of ketoacidosis:

- $\operatorname{mild}(\mathrm{pH}<7.3$; bicarbonate $<15 \mathrm{mmol} / \mathrm{l})$,

- moderate $(\mathrm{pH}<7.2$; bicarbonate $<10 \mathrm{mmol} / \mathrm{l})$,

- severe $(\mathrm{pH}<7.1$; bicarbonate $<5 \mathrm{mmol} / \mathrm{l})$

[Wolfsdorf et al. 2007].

The following treatment aims should be targeted in the event of ketoacidosis:

- circulatory stabilization with initial volume bolus with isotonic solution,

- then slow balancing-out of fluids and electrolytes,

- gradual normalization of blood sugar,

- balancing-out of acidosis and ketosis,

- avoidance of therapy complications (cerebral edema, hypokaliemia),

- diagnosis and treatment of triggering factors

[Australasian Paediatric Endocrine Group et al. 2005b; Wolfsdorf et al. 2014] ( $\triangleright$ Table. 2).

During treatment of severe diabetic ketoacidosis, clinical observation and monitoring should be carried out at least hourly [Australasian Paediatric Endocrine Group et al. 2005a; Edge et al., 2006; Wolfsdorf et al. 2014].

Pediatric patients with severe ketoacidosis and elevated risk of cerebral edema should be immediately treated by an experienced pediatric diabetes team in an intensive care unit or in a specialized diabetes ward with comparable equipment.

Patients with suspected cerebral edema should be treated in an intensive care unit in cooperation with an experienced diabetic 
- Table. 2 Pharmaceutical treatment of ketoacidosis (taking into consideration the monitoring of electrolytes, pH, blood sugar, ketone bodies).

\begin{tabular}{|c|c|c|c|}
\hline $\begin{array}{l}\text { Objective of treatment / } \\
\text { Indication }\end{array}$ & Medicinal product & Dose & Timespan) \\
\hline $\begin{array}{l}\text { Initial stabilization of } \\
\text { circulation (if necessary }\end{array}$ & $\mathrm{NaCl} 0.9 \%$ & $10-20 \mathrm{ml} / \mathrm{kg}$ i.v. & Immediately over $1-2 \mathrm{~h}$ \\
\hline $\begin{array}{l}\text { Balancing-out of fluids } \\
\text { after initial stabilization of } \\
\text { circulation }\end{array}$ & $\begin{array}{l}\mathrm{NaCl} 0.9 \% \text { or Ringer's } \\
\text { solution after } 4-6 \mathrm{~h} \text {, also } \\
\mathrm{NaCl} 0.45 \% \text { possible }\end{array}$ & $\begin{array}{l}\text { Maximal i. v. daily dose }<1.5 \text { to } \\
2 x \text { maintenance requirements } \\
\text { for age/weight/body surface }\end{array}$ & At least over $36-48 \mathrm{~h}$ \\
\hline Lowering of blood glucose & Normal insulin & $\begin{array}{l}0.1 \mathrm{U} / \mathrm{kg} / \mathrm{h} \mathrm{i} . \mathrm{v} \text {. with younger } \\
\text { child } 0.05 \mathrm{Ug} / \mathrm{kg}\end{array}$ & $\begin{array}{l}\text { Start of insulin administration } 1-2 \mathrm{~h} \text { after start of volume } \\
\text { administration; no interruption of insulin intake until } \\
\mathrm{pH}>7.3 \text {; blood sugar decrease by } 2-5 \mathrm{mmol} / \mathrm{l} / \mathrm{h} \\
(36-90 \mathrm{mg} / \mathrm{dl} / \mathrm{h})\end{array}$ \\
\hline Avoidance of hypoglycemia & Glucose & $\begin{array}{l}\text { Final concentration: } 5 \% \text { glucose } \\
\text { / } 0.45 \% \mathrm{NaCl} \text { solution }\end{array}$ & $\begin{array}{l}\text { Start from blood glucose of } 15 \mathrm{mmol} / /(270 \mathrm{mg} / \mathrm{dl}) \text { or with } \\
\text { decrease in blood glucose }>5 \mathrm{mmol} / / / \mathrm{h}(90 \mathrm{mg} / \mathrm{dl} / \mathrm{h})\end{array}$ \\
\hline Potassium balancing & $\mathrm{KCl}$ & $\begin{array}{l}40 \mathrm{mmol} / / \text { volume; } 5 \mathrm{mmol} / \mathrm{kg} / \\
\text { day i.v.; not }>0.05 \mathrm{mmol} / \mathrm{kg} / \mathrm{h}\end{array}$ & $\begin{array}{l}\text { With hypokalemia immediately, with normokalemia at } \\
\text { start of insulin administration, with hyperkalemia only } \\
\text { after re-initiation of urine production; continuous } \\
\text { administration until completion of volume balancing }\end{array}$ \\
\hline
\end{tabular}

team [Australasian Paediatric Endocrine Group et al. 2005b; Wolfsdorf et al. 2014].

Patients with significant signs of cerebral edema should be treated immediately with mannitol or hypertonic saline solution prior to the initiation of further diagnostic measures (MRI) [Australasian Paediatric Endocrine Group et al. 2005a; Fiordalisi et al. 2007; Hanas et al. 2007; Roberts et al. 2001; Franklin et al. 1982; Banks and Furyk 2008; Wolfsdorf et al. 2014].

Regarding the therapeutic effectiveness of early, possibly repeated (after $30 \mathrm{~min}$.) intravenous administration of mannitol (0.5$1 \mathrm{~g} / \mathrm{kg}$ ) over $10-15 \mathrm{~min}$ in the event of symptomatic cerebral edema, case reports and case series are available in the literature [Fiordalisi et al. 2007; Hanas et al. 2007; Roberts et al. 2001; Franklin et al. 1982].

\subsection{Hypoglycemia}

Hypoglycemic episodes are the most common acute complications in diabetes [Diabetes Control and Complications Trial Research Group 1994].

They are classified as either

- mild hypoglycemic episodes, which are easily relieved by the patient by consuming fast-acting carbohydrates or

- severe hypoglycemic episodes, which can be remedied only through help from another person due to limited or loss of consciousness. In addition to unconsciousness, severe hypoglycemic episodes may cause seizures.

Children and adolescents with type 1 diabetes should always carry fast-acting carbohydrates with them in the form of glucose or similar substances so that they can act quickly in the event of a mild hypoglycemic episode in order to prevent severe hypoglycemic episodes. Parents or other primary caregivers should be trained in the administration of glucagon injections and other immediate measures.

Caregivers, for instance in preschools and child care facilities, as well as teachers in schools should also receive instruction on the risks and treatment options for hypoglycemia.
In case of hypoglycemia unawareness, a higher blood glucose level should temporarily be aimed for [Australasian Paediatric Endocrine Group et al. 2005a; Clarke et al. 2008a].

\section{Long-term Complications and Screening}

The HbA1c value should be determined at least every 3 months in order to monitor metabolic control [Diabetes Control and Complications Trial Research Group 1994; Nathan et al. 2005; White et al. 2008]. All further long-term examinations are detailed in \ Table. 3.

\section{Associated Autoimmune Diseases}

\subsection{Diagnosis and treatment of thyroid diseases}

In children and adolescents affected by diabetes, the levels of TSH and thyroid autoantibodies (anti-TPO, anti-Tg) should be determined upon diabetes onset, as well as regularly at annual or biennial intervals, or in the event of relevant symptoms [Australasian Paediatric Endocrine Group et al. 2005a; Bangstad et al. 2007; Silverstein et al. 2005; Kordonouri et al. 2011].

If TPO autoantibodies are present and/or a TSH increase is observed, an ultrasound of the thyroid should be carried out.

For treatment of autoimmune hypothyroidism or goiter, L-thyroxine should be employed acc. to the therapy plan ( $\mathbf{F i g . ~ 1 ) . ~}$

\subsection{Diagnosis and treatment of celiac disease}

Children and adolescents affected by diabetes should be examined for a potential celiac disease diagnosis upon diabetes onset, as well as regularly at annual or biennial intervals, or in the event of relevant symptoms [Australasian Paediatric Endocrine Group et al. 2005a; Hill et al. 2005; Silverstein et al. 2005; Kordonouri et al. 2007; Kordonouri et al. 2014; Kordonouri et al. 2011].

In case of (serologically and bioptically) confirmed celiac disease with symptoms or extra-intestinal manifestations, a gluten-free 
> Table. 3 Long-term complications: screening examinations and interventions.

\begin{tabular}{|c|c|c|}
\hline $\begin{array}{l}\text { Screening examination and } \\
\text { intervals }\end{array}$ & Recommended screening method(s) & Interventions \\
\hline $\begin{array}{l}\text { 1. Retinopathy: } \\
\text { - every } 1-2 \text { years; } \\
\text { - from the age of } 11 \text { years or as of } \\
5 \text { years of diabetes }\end{array}$ & $\begin{array}{l}\text { binocular bimicroscopic ophthalmoscopy in } \\
\text { mydriasis by experienced ophthalmologist }\end{array}$ & $\begin{array}{l}\text { - improvement of glycemic control } \\
\text { - normalize blood pressure } \\
\text { - normalize dyslipidemia } \\
\text { - laser therapy } \\
\text { - intravitreal injections }\end{array}$ \\
\hline $\begin{array}{l}\text { 2. Nephropathy: } \\
\text { - every year; } \\
\text { - from the age of } 11 \text { years or as of } \\
5 \text { years of diabetes }\end{array}$ & $\begin{array}{l}\text { evidence of microalbuminuria: } \\
\text { - concentration measurement: } 20-200 \mathrm{mg} / \mathrm{l} \\
\text { - albumin excretion rate }>20-<200 \mu \mathrm{g} / \mathrm{min} \\
\text { - albumin-creatinine ratio }\end{array}$ & $\begin{array}{l}\text { - improvement of glycemic control } \\
\text { - in case of hypertension + microalbuminuria: } \\
\text { - ACE inhibitor } \\
\text { - AT1 blocker } \\
\text { - persisting microalbuminuria without hypertension: } \\
\text { consider ACE inhibitor } \\
\text { - nicotine abstinence }\end{array}$ \\
\hline $\begin{array}{l}\text { 3. Neuropathy: } \\
\text { - yearly from the age of } 11 \text { or as } \\
\text { of } 5 \text { years of diabetes in the } \\
\text { event of long-term poor } \\
\text { metabolic status }\end{array}$ & $\begin{array}{l}\text { - medical history } \\
\text { - pressure sensation (monofilament) } \\
\text { - vibration perception (tuning fork test) } \\
\text { - proprioceptive reflexes }\end{array}$ & - improvement of glycemic control \\
\hline $\begin{array}{l}\text { 4. Hypertension: } \\
\text { - every } 3 \text { months, at least once a } \\
\text { year, from the age of } 11\end{array}$ & $\begin{array}{l}\text { - } R \text { RR (resting) } \\
\text { - } 24 \mathrm{~h} \text { RR at least twice }>95 \text { th percentile or } \\
\text { microalbuminuria }\end{array}$ & $\begin{array}{l}\text { - lifestyle intervention (physical activity, salt restriction, } \\
\text { weight reduction, reduction of alcohol, nicotine) } \\
\text { - if not successful: ACE inhibitor; in the event of } \\
\text { contraindication or adverse effects: AT1-blocker; if } \\
\text { required, combination with other medicines }\end{array}$ \\
\hline $\begin{array}{l}\text { 5. Hyperlipidemia } \\
\text { - within } 1 \text { year of diagnosis } \\
\text { - then every } 2 \text { years } \\
\text { - prepubertal every } 5 \text { years }\end{array}$ & $\begin{array}{l}\text { determination of } \\
\text { - total cholesterol } \\
\text { - HDL } \\
\text { - LDL } \\
\text { - triglycerides }\end{array}$ & $\begin{array}{l}\text { - dietary therapy } \\
\text { - if not successful: statins from the age of } 8 \text { years }\end{array}$ \\
\hline
\end{tabular}
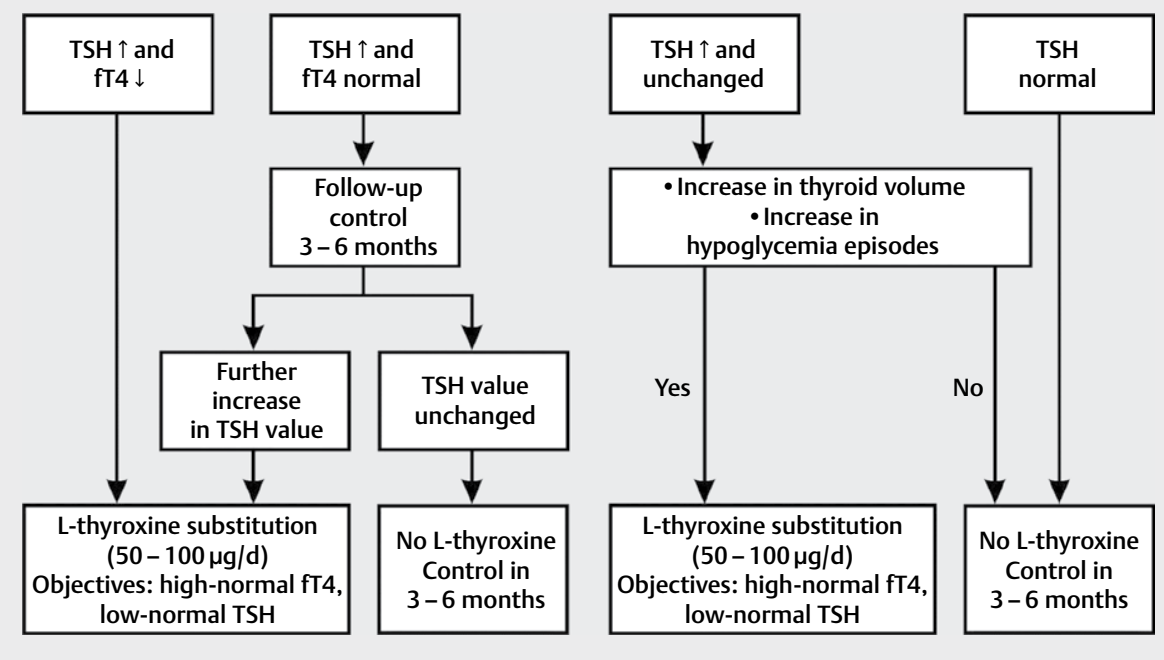

-Fig. 1 Treatment plan for Hashimoto's thyroiditis [rerif].

diet should be introduced [Hansen et al. 2006; Amin et al. 2002; Hill et al. 2005; Lewis et al. 1996; Kordonouri et al. 2011].

In asymptomatic patients, the indication for gluten-free diet and further follow-up should be discussed with the pediatric gastroenterologist.

\section{Other Forms of Diabetes in Childhood and Adolescence}

\subsection{Type 2 diabetes}

Type 2 diabetes in adolescents should be diagnosed based on the limit values for fasting blood glucose and an oral glucose tolerance test (OGTT) in compliance with the standard or reference method. 


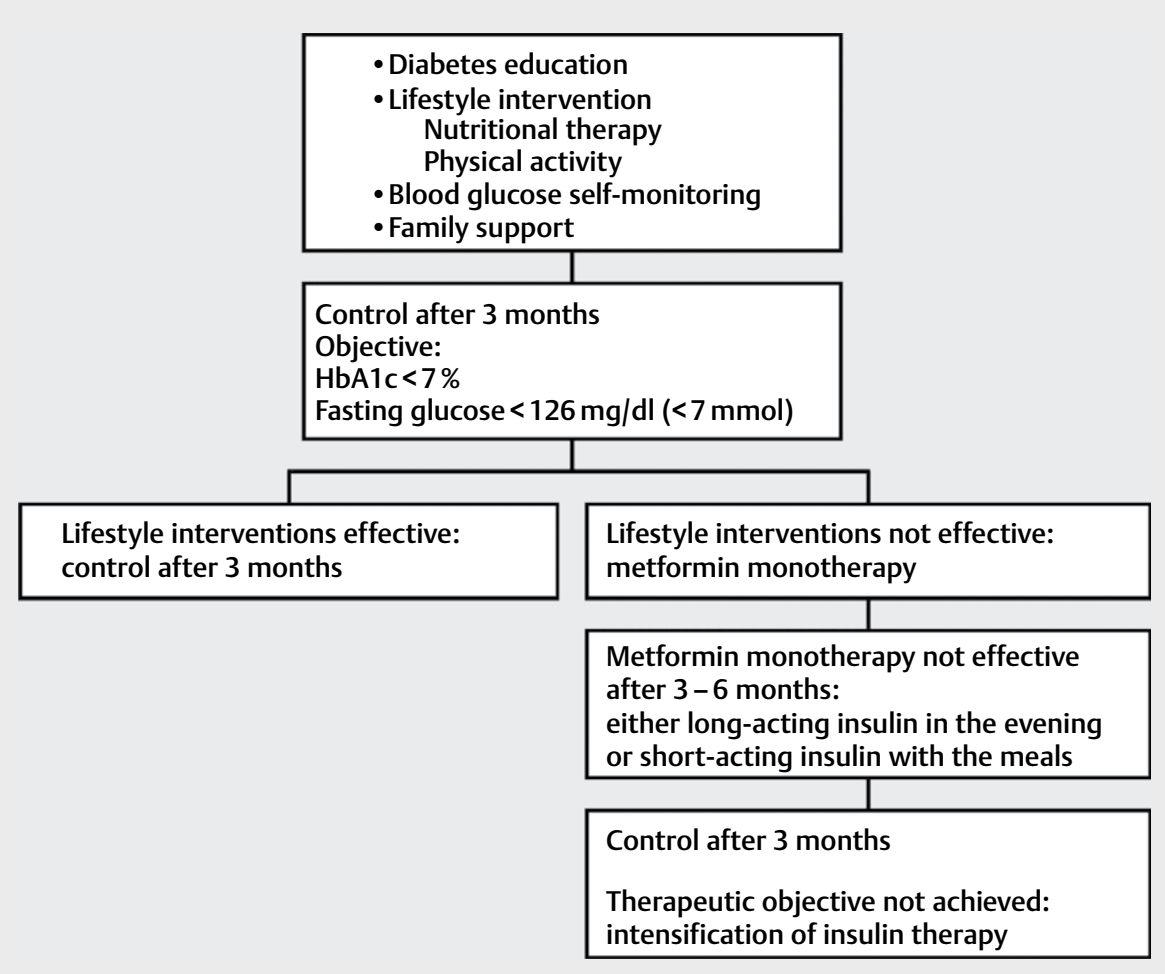

Fig. 2 Treatment plan for type 2 diabetes in children and adolescents [rerif].

If the following limit values are exceeded, the result of an asymptomatic patient should be confirmed via a second test on another day:

- fasting blood sugar: $>126 \mathrm{mg} / \mathrm{dl}$ (>7.0 mmol/l)

- OGTT: 2 h value $>200 \mathrm{mg} / \mathrm{dl}$ (>11.1 mmol/l)

[Genuth et al. 2003].

Additional laboratory tests may be of help for differentiating between type 2 and type 1 diabetes:

- C-peptide

- diabetes-specific autoantibodies (GAD, iA2, ICA, IAA)

[Alberti et al. 2004; Genuth et al. 2003].

For the treatment of type 2 diabetes in adolescents, a fasting blood glucose level of $<126 \mathrm{mg} / \mathrm{dl}$ and an $\mathrm{HbA} 1 \mathrm{c}$ value of $<7 \%$ should be aimed for [Zeitler et al. 2014; UK Prospective Diabetes Study UKPDS Group (1998b); Holman et al. 2008]. A detailled treatment plan according to [Alberti et al. 2004] is given in Figure 2 (- Fig. 2).

The schooling for adolescents with type 2 diabetes should include dietary advice and guidance on physical activity within the framework of a structured obesity program [Reinehr et al., 2007; Arbeitsgemeinschaft Adipositas im Kindes- und Jugendalter (AGA): Therapie der Adipositas im Kindes- und Jugendalter (2008)].

Moreover, the content relevant to type 2 diabetes should be carried over from the type 1 diabetes schooling on an individually adjusted, modular basis.

In the event of an initial $\mathrm{HbA} 1 \mathrm{c}$ value of $\geq 9 \%$ or spontaneous hyperglycemia of $\geq 250 \mathrm{mg} / \mathrm{dl}$ and in case of signs of absolute insulin deficiency (ketonuria, ketoacidosis), an initial insulin treatment should be started. In all other cases, metformin is the first- line drug for the pharmaceutical treatment of children and adolescents [Shimazaki et al. 2007; UK Prospective Diabetes Study UKPDS Group (1998a); Jones et al. 2002; Jones et al. 2002; Gottschalk et al. 2007; Zeitler et al. 2014].

\subsection{Monogenic diabetes}

Due to the significance for therapy, long-term prognosis and genetic counseling of families, molecular genetic diagnostics of the MODY forms ( Table. 4 ) are recommended in the event of substantiated suspicion of these. The most common forms are listed according to [Hattersley et al. 2006; Ellard et al. 2008] in Table 4.

Before the affected genes are sequenced, counseling and information must be provided pursuant to the German Gene Diagnostics Law (Gendiagnostikgesetz), particularly with regard to the right to know and the right not to know about genetic information [Murphy et al. 2008; McDonald et al. 2013; Ellard et al. 2008; [Badenhoop et al. 2008]; Gene diagnostics law 2009].

\subsection{Neonatal diabetes mellitus (NDM)}

One particular form of genetic diabetes is neonatal diabetes mellitus (NDM), which develops within the first 6 months of life. From a clinical perspective, two subgroups are distinguished, namely transient (TNDM) and permanent (PNDM) neonatal diabetes mellitus. Regarding the diagnosis of neonatal diabetes or manifestation of diabetes within the course of 6 months of life, see ( $\triangleright$ Table. 5 ).

In the event of etiologically undetermined neonatal diabetes mellitus and diabetes mellitus which occurs within the first 6 months of life, a molecular-genetic analysis should be carried out as early on as possible in order to initiate appropriate therapy as 
- Table. 4 The most common MODY forms and their clinical characteristics.

\begin{tabular}{|c|c|c|c|}
\hline $\begin{array}{l}\text { MODY type (interna- } \\
\text { tional proportion in } \\
\text { percent); heredity }\end{array}$ & $\begin{array}{l}\text { Age (in years) at } \\
\text { manifestation }\end{array}$ & $\begin{array}{l}\text { Severity of } \\
\text { hyperglycemia }\end{array}$ & Clinical presentation \\
\hline $\begin{array}{l}\text { HNF1A-MODY (MODY3) } \\
\text { HNF-1 } \alpha-(20-50 \%) \\
\text { autosomal-dominant }\end{array}$ & $14(4-18)$ & $\begin{array}{l}\text { severely } \\
\text { hyperglycemic }\end{array}$ & $\begin{array}{l}\text { - } \text { significant rise in blood glucose level in the OGTT (>90 mg/dl), low renal } \\
\text { threshold (frequent glycosuria associated with blood glucose levels } \\
\quad<180 \mathrm{mg} / \mathrm{dl}[<10 \mathrm{mmol} / \mathrm{l}]), \\
\text { - increasing hyperglycemia with age, } \\
\text { - } \text { response to sulfonylurea/glinides }\end{array}$ \\
\hline $\begin{array}{l}\text { GCK-MODY (MODY2) } \\
\text { glucokinase (20-50\%) } \\
\text { autosomal-dominant }\end{array}$ & $10(0-18)$ & $\begin{array}{l}\text { mildly } \\
\text { hyperglycemic }\end{array}$ & $\begin{aligned} \text { - } & \text { often discovered incidentally, } \\
\text { - } & \text { fasting blood glucose level slightly elevated between } 99 \text { and } 144 \mathrm{mg} / \mathrm{dl} \text {, } \\
& (5.5-8 \mathrm{mmol} / \mathrm{l}) \text {, } \\
\text { - } & \text { small blood glucose increase in the OGTT (by<63 mg/dl or }<3.5 \mathrm{mmol} / \mathrm{l} \text { ), } \\
\text { - } & \text { no blood glucose deterioration with age, } \\
\text { - } & \text { rarely any microvascular or macrovascular complications, even without } \\
& \text { pharmaceutical treatment }\end{aligned}$ \\
\hline $\begin{array}{l}\text { HNF4A-MODY (MODY1) } \\
\text { HNF-4 } \alpha-(1-5 \%) \\
\text { autosomal-dominant }\end{array}$ & $17(5-18)$ & $\begin{array}{l}\text { significantly } \\
\text { hyperglycemic }\end{array}$ & $\begin{array}{l}\text { - similar to HNF-1 } \alpha \text {, but renal threshold normal, } \\
\text { - response to sulfonylurea }\end{array}$ \\
\hline
\end{tabular}

- Table. 5 Neonatal diabetes - diagnostic procedure.

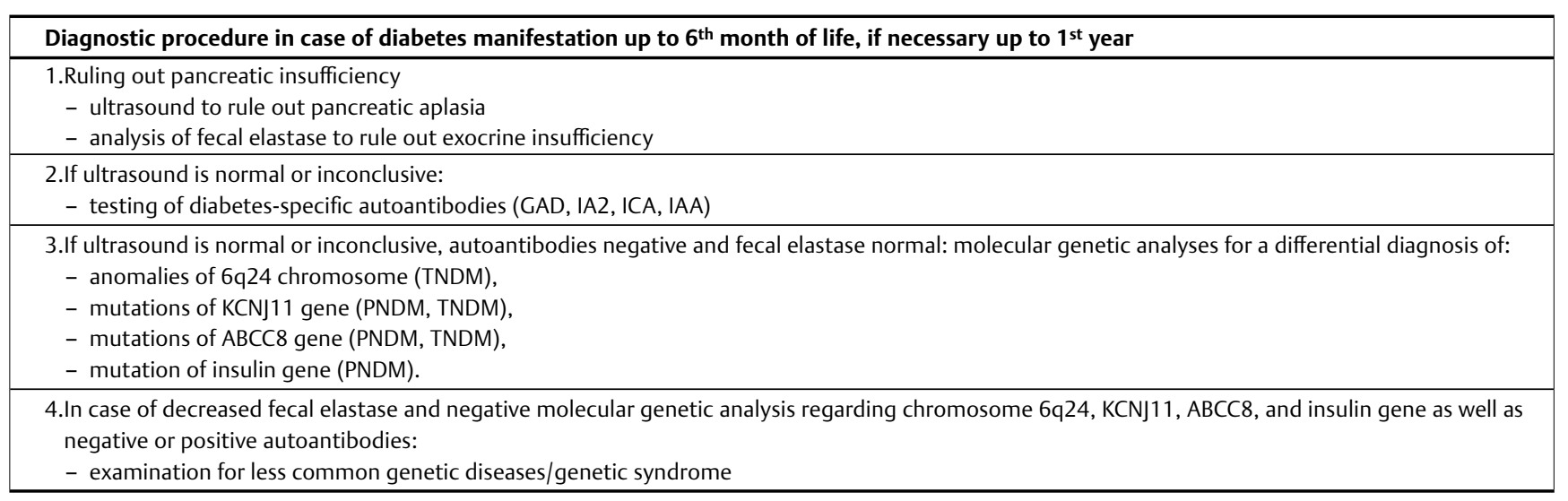

soon as possible in case of sulfonylurea-sensitive mutations [Flanagan et al. 2006; Babenko et al. 2006; Klupa et al. 2008; Battaglia et al. 2012; Shah et al. 2012].

Initially, insulin therapy should always be carried out in case of neonatal diabetes. If a KCNJ11 or ABCC 8 gene mutation is present, treatment with sulfonylurea should be attempted as early as possible [Hattersley et al. 2006; Pearson et al. 2006 I; Mlynarski et al. 2007; Koster et al. 2008; Slingerland et al. 2008; Thurber et al., (2015)].

\subsection{Cystic fibrosis-related diabetes}

Since cystic fibrosis-related diabetes (CFRD) is often difficult to clinically diagnose, children with cystic fibrosis should undergo an annual glucose tolerance test after 10 years of age [Lanng et al. 1994].

In case of a confirmed diabetes diagnosis, treatment of CFRD should be initiated [Nousia-Arvanitakis et al. 2001; Rolon et al. 2001; Lanng et al. 1994; Dobson et al. 2002].

For long-term therapy of CFRD, insulin should be used. In the first 12 months after diagnosis, therapy can, however, be attempted with glinides or sulfonylurea [Ballmann et al. 2014; O'Riordan et al. 2008].
In the event of cystic fibrosis, a diet high in fat and calories should be adhered to even after diabetes diagnosis. Reduction of calories is contraindicated [O'Riordan et al. 2008].

\section{Imprint}

The evidence-based guidelines were prepared on behalf of the German Diabetes Society (DDG). The German Diabetes Society is represented by the president responsible (2015-2017 Prof. Dr. B. Gallwitz) and the guidelines project manager of the DDG (Prof. Dr. Monika Kellerer).

The guidelines group comprises members of the German Pediatric Diabetology Association (AGPD), members of the 2009 guidelines group as well as a patient representative.

\section{Guidelines Expert Group Responsible For 2015 Edition}

Prof. Dr. A. Neu, Tübingen (coordinator)

J. Bürger-Büsing, Kaiserslautern (patient representative) Prof. Dr. T. Danne, Hannover 


\section{Dr. A. Dost, Jena}

Dr. M. Holder, Stuttgart Prof. Dr. R. W. Holl, Ulm

Prof. Dr. P.-M. Holterhus, Kiel PD Dr. T. Kapellen, Leipzig

Prof. Dr. B. Karges, Aachen

Prof. Dr. O. Kordonouri, Hannover Prof. Dr. K. Lange, Hannover

S. Müller, Ennepetal PD Dr. K. Raile, Berlin

Dr. R. Schweizer, Tübingen Dr. S. von Sengbusch, Lübeck Dr. R. Stachow, Westerland Dr. V. Wagner, Rostock

PD Dr. S. Wiegand, Berlin

Dr. R. Ziegler, Münster

\section{Literature Research}

Dr. Barbara Buchberger (MPH), Hendrick Huppertz, Beate Kossmann, Laura Krabbe, Dr. Jessica Tajana Mattivi at the endowed chair of medical management of the Duisburg-Essen university (head Prof. Dr. Jürgen Wasem)

\section{Methodological Support}

Dr. Monika Nothacker, Berlin, Arbeitsgemeinschaft der wissenschaftlichen medizinischen Fachgesellschaften (AWMF)

Editorial work:

Andrea Haring, Berlin Cornelia Berg, Tübingen

\section{External Reviewers}

Prof. Dr. H. Krude

Specialist in Pediatrics, Additional Further Training in pediatric endocrinology and diabetology, for the German Association for Pediatric Endocrinology (Arbeitsgemeinschaft Pädiatrische Endokrinologie [APE]), Berlin, Germany (diabetes and thyroid diseases)

\section{Prof. Dr. K. P. Zimmer}

Specialist in Pediatrics, Additional Further Training in pediatric gastro-enterology, Gießen (diabetes and celiac disease)

Prof. Dr. M. Ballmann

Specialist in Pediatrics, Additional Further Training in pediatric pneumology, for the German working group of pediatric pneumology, Siegen (cystic fibrosis-associated diabetes)

Prof. Dr. A. Fritsche Specialist in internal medicine, diabetologist, Tübingen

\section{Coordination Of the Revision 2013-2015}

Prof. Dr. A. Neu, Tübingen

\section{Literature}

Literature accessible online at:

http://dx.doi.org/10.1055/a-0869-0210

\section{First Publication}

This is an updated version of the publication: Neu A:, Bürger- Büsing J, Danne T, Dost A, Holder M, Holl RW, Holterhus P-M, Kapellen T, Karges B, Kordonouri O, Müller S, Raile K, Schweizer R, von Sengbusch S, Stachow R, Wagner V, Wiegand S, Ziegler R. Diagnostik, Therapie und Verlaufskontrolle des Diabetes mellitus im Kindesund Jugendalter. Diabetologie 2016; 11 (Suppl 2): 159-169

\section{Conflicts of Interest}

The conflicts of interest of all members of the guidelines group are detailed exhaustively in the long version of the guidelines (Table 32). 


\section{Supplementary Material}

\section{References}

[1] Agency for Health Care Policy and Research (AHCPR): Acute Pain Management: Operative or Medical Procedures and Trauma. Clinical Practice Guideline., Public Health Service, U.S. Department of Health and Human Services, Rockville, Md 1992

[2] Ahern JA, Ramchandani N, Cooper J et al. Using a primary nurse manager to implement DCCT recommendations in a large pediatric program. Diabetes Educ 2000; 26: 990-994, EK III

[3] Al Hanshi S, Shann F. Insulin infused at 0.05 versus 0.1 units $/ \mathrm{kg} / \mathrm{hr}$ in children admitted to intensive care with diabetic ketoacidosis. Pediatr Crit Care Med 2011; 12: 137-140, EK III

[4] Alberti G, Zimmet P, Shaw J et al. Type 2 diabetes in the young: The evolving epidemic: The international diabetes federation consensus workshop. Diabetes Care 2004; 27: 1798-1811, EK IV

[5] Ambrosino JM, Fennie K, Whittemore R et al. Short-term effects of coping skills training in school-age children with type 1 diabetes. Pediatr Diabetes 2008; 9: 74-82, EK Ib

[6] American Diabetes Association (ADA). Management of dyslipidemia in children and adolescents with diabetes. DiabetesCare 2003; 26 : 2194-2197, EK IV

[7] American Diabetes Association (ADA). Standards of medical care in diabetes-2009. Diabetes Care. 2009; 32: (Suppl 1): S13-S61, EK IV

[8] American Diabetes Association (ADA). Standards of Medical Care in Diabetes - 2015. Section 11: Children and Adolescents. Diabetes Care 2015; 38: S70-S76, EK IV

[9] Amin R, Murphy N, Edge J et al. A longitudinal study of the effects of a gluten-free diet on glycemic control and weight gain in subjects with type 1 diabetes and celiac disease. Diabetes Care 2002; 25: 1117-1122, EK III

[10] Andersen HU, Lanng S, Pressler T et al. Cystic fibrosis-related diabetes: the presence of microvascular diabetes complications. Diabetes Care 2006; 29: 2660-2663, EK III

[11] Anderson B, Ho J, Brackett J et al. Parental involvement in diabetes management tasks: relationships to blood glucose monitoring adherence and metabolic control in young adolescents with insulindependent diabetes mellitus. J Pediatr 1997; 130: 257-265, EK III

[12] Anderson BJ, Brackett J, Ho J et al. An office-based intervention to maintain parent-adolescent teamwork in diabetes management. Impact on parent involvement, family conflict, and subsequent glycemic control. Diabetes Care 1999; 22: 713-721, EK IIb

[13] Anderson RM, Funnell MM, Butler PM et al. Patient empowerment. Results of a randomized controlled trial. Diabetes Care 1995; 18: 943-949, EK lb

[14] Appel LJ, Champagne CM, Harsha DW et al. Effects of comprehensive lifestyle modification on blood pressure control: Main results of the PREMIER clinical trial. JAMA 2003; 289: 2083-2093, EK Ib

[15] Arbeitsgemeinschaft Adipositas im Kindes- und Jugendalter (AGA): Therapie der Adipositas im Kindes- und Jugendalter. Evidenzbasierte Leitlinie der Arbeitsgemeinschaft Adipositas im Kindes- und Jugendalter (AGA) und der beteiligten medizinisch-wissenschaftlichen Fachgesellschaften, Berufsverbände und weiterer Organisationen, AGA, Ulm. 2008; EK IV

[16] Arbeitsgemeinschaft für Pädiatrische Diabetologie. Untersuchungen auf diabetische Folgeerkrankungen an Augen, Nieren und Nerven bei pädiatrischen Diabetespatienten. Diabet Inform 1998; 20: 124-127

[17] Arbeitsgemeinschaft für Pädiatrische Diabetologie. Stellungnahme zur Notwendigkeit eines Kinderpsychologen in der Langzeitbetreuung von Kindern und Jugendlichen mit Diabetes mellitus, 20 ed., AGPD. 1999;
[18] Arbeitsgemeinschaft für Pädiatrische Diabetologie (AGPD). Kinder mit Diabetes im Kindergarten. Informationen für Erzieherinnen und Erzieher in Kindergärten. http://www.diabetes-kinder.de 2009; EK IV

[19] Arbeitsgemeinschaft für Pädiatrische Diabetologie (AGPD). Kinder mit Diabetes in der Schule. Informationen für Lehrerinnen und Lehrer. http://www.diabetes-kinder.de 2010; EK IV

[20] Arbeitsgemeinschaft Pädiatrische Diabetologie (AGPD). Kosten der ambulanten Langzeitbetreuung. 1999; EK IV

[21] Astrup A, Ryan L, Grunwald GK et al. The role of dietary fat in body fatness: Evidence from a preliminary meta-analysis of ad libitum lowfat dietary intervention studies. Br J Nutr 2000; 83: (Suppl 1): S25-S32, EK la

[22] Australasian Paediatric Endocrine Group, Department of Health and Ageing, National Health and Medical Research Council (NHMRC). Clinical practice guidelines: Type 1 diabetes in children and adolescents. 2005; EK IV

[23] Australasian Paediatric Endocrine Group, Department of Health and Ageing, National Health and Medical Research Council (NHMRC). Clinical practice guidelines: Type 1 diabetes in children and adolescents.. 2005; EK IV

[24] Australasian Paediatric Endocrine Group, Department of Health and Ageing, National Health and Medical Research Council (NHMRC). Clinical practice guidelines: Type 1 diabetes in children and adolescents. 2005; EK Ib

[25] Australasian Paediatric Endocrine Group, Department of Health and Ageing, National Health and Medical Research Council (NHMRC). Clinical practice guidelines: Type 1 diabetes in children and adolescents. 2005; EK IIb-III

[26] Australasian Paediatric Endocrine Group, Department of Health and Ageing, National Health and Medical Research Council (NHMRC). Clinical practice guidelines: Type 1 diabetes in children and adolescents. 2005; EK III

[27] Australasian Paediatric Endocrine Group, Department of Health and Ageing, National Health and Medical Research Council (NHMRC). Clinical practice guidelines: Type 1 diabetes in children and adolescents. 2005; EK III/IV

[28] Babcock DS. Thyroid disease in the pediatric patient: Emphasizing imaging with sonography. Pediatr Radiol 2006; 36: 299-308 quiz, EK IV

[29] Babenko AP, Polak M, Cave $\mathrm{H}$ et al. Activating mutations in the ABCC8 gene in neonatal diabetes mellitus. N Engl J Med 2006; 355: 456-466, EK III

[30] Bachran R, Beyer P, Klinkert C et al. Basal rates and circadian profiles in continuous subcutaneous insulin infusion (CSII) differ for preschool children, prepubertal children, adolescents and young adults. Pediatr Diabetes 2012; 13: 1-5, EK III

[31] Badenhoop K, Kordonouri O, Machicao F. Empfehlungen zur molekulargenetischen Diagnostik bei Verdacht auf MODY, DDG. 2008; EK IV

[32] Baechle C, Castillo K, Strassburger K et al. Is disordered eating behavior more prevalent in adolescents with early-onset type 1 diabetes than in their representative peers? Int J Eat Disord 2014; 47: 342-352, EK IIb

[33] Ballmann M, Hubert D, Assael BM et al. Open randomised prospective comparative multi-centre intervention study of patients with cystic fibrosis and early diagnosed diabetes mellitus. BMC Pediatr 2014; 14: 70, EK Ib

[34] Bangstad H], Danne T, Deeb LC et al. Insulin treatment. ISPADclinical practice consensus guidelines 2006 - 2007. Pediatr Diabetes 2007; 8: 88-102, EK Ib

[35] Bangstad H], Danne T, Deeb LC et al. Insulin treatment. ISPADclinical practice consensus guidelines 2006 - 2007. Pediatr Diabetes 2007; 8: 88-102, EK IV 
[36] Banks C], Furyk JS. Review article: hypertonic saline use in the emergency department. Emerg Med Australas 2008; 20: 294-305, EK III

[37] Barlow JH, Ellard DR. Psycho-educational interventions for children with chronic disease, parents and siblings: An overview of the research evidence base. Child Care Health Dev 2004; 30: 637-645, EK Ib

[38] Barnard K, Thomas S, Royle P et al. Fear of hypoglycaemia in parents of young children with type 1 diabetes: A systematic review. BMC Pediatr 2010; 10: 50, EK la

[39] Barnea-Goraly N, Raman M, Mazaika P et al. Alterations in white matter structure in young children with type 1 diabetes. Diabetes Care 2014; 37: 332-340, EK III

[40] Battaglia D, Lin YW, Brogna C et al. Glyburide ameliorates motor coordination and glucose homeostasis in a child with diabetes associated with the KCNJ11 / S225 T, del226 - 232 mutation. Pediatr Diabetes 2012; 13: 656-660

[41] Battelino T, Conget I, Olsen B et al. The use and efficacy of continuous glucose monitoring in type 1 diabetes treated with insulin pump therapy: a randomised controlled trial. Diabetologia 2012; 55 : 3155-3162, EK Ib

[42] Battelino T, Phillip M, Bratina N et al. Effect of continuous glucose monitoring on hypoglycemia in type 1 diabetes. Diabetes Care 2011; 34: 795-800, EK Ib

[43] Becker M, Galler A, Raile K. Meglitinide analogues in adolescent patients with HNF1A-MODY (MODY 3). Pediatrics 2014; 133 : e775-e779

[44] Bell KJ, Barclay AW, Petocz P et al. Efficacy of carbohydrate counting in type 1 diabetes: A systematic reviewand meta-analysis. Lancet Diabetes Endocrinol 2014; 2: 133-140

[45] Berg CA, Schindler I, Maharajh S. Adolescents' and mothers' perceptions of the cognitive and relational functions of collaboration and adjustment in dealing with type 1 diabetes. J Fam Psychol 2008; 22: $865-874$, EK III

[46] Bergenstal RM, Klonoff DC, Garg SK et al. Threshold-based insulin-pump interruption for reduction of hypoglycemia. N Engl ] Med 2013; 369: 224-232, EK Ib

[47] Bergenstal RM, Tamborlane WV, Ahmann A et al. Effectiveness of sensor-augmented insulin-pump therapy in type 1 diabetes. $N$ Engl J Med 2010; 363: 311-320, EK Ib

[48] Biester T, Blaesig S, Remus K et al. Insulin degludec's ultra-long pharmacokinetic properties observed in adults are retained in children and adolescents with type 1 diabetes. Pediatr Diabetes 2014; 15: 27-33

[49] Biondi B, Cooper DS. The clinical significance of subclinical thyroid dysfunction. Endocr Rev 2008; 29: 76-131, EK Ib-IV

[50] Bitsko MJ, Bean MK, Bart S, Foster RH, Thacker L, Francis GL.. Psychological treatment improves hemoglobin A1c outcomes in adolescents with type 1 diabetes mellitus. J Clin Psychol Med Settings 2013; 20: 333-342, EK III

[51] Blackman SM, Raghinaru D, Adi S et al. Insulin pump use in young children in the T1D Exchange clinic registry is associated with lower hemoglobin A1c levels than injection therapy. Pediatr Diabetes 2014; 15: 564-572, EK IIb

[52] Blank W, Braun B. Sonografie der Schilddrüse - Teil 2: Schilddrüsenentzündungen, Schilddrüsenfunktionsstörungen und Interventionen. Ultraschall in Med 2008; 29: 128-149, EK IV

[53] Blankfield AJ, Holahan B. Family support, coping strategies and depressive symptoms among mothers of children with diabetes. J Fam Psychol 1996; 10: 173-179, EK III

[54] Bläsig S, Remus K, Danne T et al. 'Fit for school': Evaluation of a training course for $5-6$ year old children with type 1 diabetes. Pediatr Diabetes 2011; 12: 72, EK III
[55] Bloomgarden ZT, Karmally W, Metzger M] et al. Randomized, controlled trial of diabetic patient education: Improved knowledge without improved metabolic status. Diabetes Care 1987; 10: 263-272, EK Ib

[56] Bonfanti R, Colombo C, Nocerino $V$ et al. Insulin gene mutations as cause of diabetes in children negative for five type 1 diabetes autoantibodies. Diabetes Care 2009; 32: 123-125

[57] Bonfig W, Kapellen T, Dost A et al. Growth in children and adolescents with type 1 diabetes. J Pediatr 2012; 160: 900-903

[58] Bonnefond A, Philippe J, Durand E et al. Whole-exome sequencing and high throughput genotyping identified KCNJ11 as the thirteenth MODY gene. PLoS One 2012; 7: e37 423

[59] Bonnefond A, Sand O, Guerin B et al. GATA6 inactivating mutations are associated with heart defects and, inconsistently, with pancreatic agenesis and diabetes. Diabetologia 2012; 55: 2845-2847

[60] Bornet F, Haardt M], Costagliola D et al. Sucrose or honey at breakfast have no additional acute hyperglycaemic effect over an isoglucidic amount of bread in type 2 diabetic patients. Diabetologia 1985; 28 : 213-217, EK Ib

[61] Brackenridge A, Wallbank H, Lawrenson RA et al. Emergency management of diabetes and hypoglycaemia. Emerg Med J 2006; 23 : 183-185, EK III

[62] Brand-Miller ], Hayne S, Petocz P et al. Low-glycemic index diets in the management of diabetes: A meta-analysis of randomized controlled trials. Diabetes Care 2003; 26: 2261-2267, EK la

[63] Brink S, Laffel L, Likitmaskul S et al. Sick day management in children and adolescents with diabetes. Pediatr Diabetes 2007; 8: 401-407, EK IV

[64] Brink S, Laffel L, Likitmaskul S et al. Sick day management in children and adolescents with diabetes. Pediatr Diabetes 2007; 8: 401-407

[65] Brown M, Ahmed ML, Clayton KL et al. Growth during childhood and final height in type 1 diabetes. Diabet Med 1994; 11: 182-187, EK III

[66] Bryden KS, Neil A, Mayou RA et al. Eating habits, body weight, and insulin misuse. A longitudinal study of teenagers and young adults with type 1 diabetes. Diabetes Care 1999; 22: 1956-1960, EK III

[67] Buckingham BA, Cameron F, Calhoun P et al. Outpatient safety assessment of an in-home predictive low-glucose suspend system with type 1 diabetes subjects at elevated risk of nocturnal hypoglycemia. Diabetes Technol Ther 2013; 15: 622-627, EK Ib

[68] Bundesarbeitsgemeinschaft für Rehabilitation (BAR). Gemeinsames Rahmenkonzept der Gesetzlichen Krankenkassen und der Gesetzlichen Rentenversicherung für die Durchführung stationärer medizinischer Leistungen der Vorsorge und Rehabilitation für Kinder und Jugendliche. http://www.bar-frankfurt.de/fileadmin/dateiliste/ publikationen/arbeitsmaterialien/downloads/Gemeinsames_Rahmenkonzept. pdf 2008;

[69] Bundesärztekammer (BÄK), Arbeitsgemeinschaft der Wissenschaftlichen Medizinischen Fachgesellschaften (AWMF), Kassenärztliche Bundesvereinigung (KBV). Nationale VersorgungsLeitlinie Diabetes. Strukturierte Schulungsprogramme - Langfassung1. Auflage. Version 3 http://doi.org/10.6101/ AZQ/000 143 2012, EK IV

[70] Bundesärztekammer (BÄK), Kassenärztliche Bundesvereinigung (KBV), Arbeitsgemeinschaft der Wissenschaftlichen Medizinischen Fachgesellschaften (AWMF). Nationales Programm für VersorgungsLeitlinien. Methoden-Report 4. Auflage http://doi.org/10.6101/ AZQ/000 0612010

[71] Cadario F, Prodam F, Bellone S et al. Transition process of patients with type 1 diabetes (T1DM) from paediatric to the adult health care service: a hospital-based approach. Clin Endocrinol (Oxf) 2009; 71: 346-350, EK III

[72] Cameron FJ, Amin R, de BC et al. ISPADClinical Practice Consensus Guidelines 2014. Diabetes in adolescence. Pediatr Diabetes 2014; 15: 245-256, EK III 
[73] Cameron F], de BC, Aanstoot HJ et al. Lessons from the Hvidoere International Study Group on childhood diabetes: Be dogmatic about outcome and flexible in approach. Pediatr Diabetes 2013; 14 : 473-480, EK III

[74] Cameron F], Scratch SE, Nadebaum C et al. Neurological consequences of diabetic ketoacidosis at initial presentation of type 1 diabetes in a prospective cohort study of children. Diabetes Care 2014; 37 : 1554-1562, EK IIb

[75] Cameron F], Skinner TC, de Beaufort CE et al. Are family factors universally related to metabolic outcomes in adolescents with Type 1 diabetes? Diabet Med 2008; 25: 463-468, EK III

[76] Canadian Diabetes Association Clinical Practice Guidelines Expert Committee. Canadian Diabetes Association 2013 Clinical Practice Guidelines for the Prevention and Management of Diabetes in Canada. Can J Diabetes 2013; 37: S1-S212, EK IV

[77] Carlsson AK, Axelsson IE, Borulf SK et al. Prevalence of IgA-antiendomysium and IgA-antigliadin autoantibodies at diagnosis of insulindependent diabetes mellitus in Swedish children and adolescents. Pediatrics 1999; 103: 1248-1252, EK III

[78] Ceriello A, Giugliano D, Quatraro A et al. Anti-oxidants showan anti-hypertensive effect in diabetic and hypertensive subjects. Clin Sci (Lond) 1991; 81: 739-742, EK Ib

[79] Chan NN, Brain HP, Feher MD. Metformin-associated lactic acidosis: A rare or very rare clinical entity? Diabet Med 1999; 16: 273-281, EK Ila

[80] Chandalia M, Garg A, Lutjohann D et al. Beneficial effects of high dietary fiber intake in patients with type 2 diabetes mellitus. $N$ Engl J Med 2000; 342: 1392-1398, EK Ib

[81] Channon SJ, Huws-Thomas MV, Rollnick S et al. A multicenter randomized controlled trial of motivational interviewing in teenagers with diabetes. Diabetes Care 2007; 30: 1390-1395, EK Ib

[82] Chetty VT, Almulla A, Odueyungbo A et al. The effect of continuous subcutaneous glucose monitoring (CGMS) versus intermittent whole blood finger-stick glucose monitoring (SBGM) on hemoglobin A1c (HBA1c) levels in Type I diabetic patients: A systematic review. Diabetes Res Clin Pract 2008; 81: 79-87, EK la

[83] Cheung N, Rogers SL, Donaghue KC et al. Retinal arteriolar dilation predicts retinopathy in adolescents with type 1 diabetes. Diabetes Care 2008; 31: 1842-1846, EK IIb

[84] Chiang JL, Kirkman MS, Laffel LM et al. Type 1 diabetes through the life span: a position statement of the American Diabetes Association. Diabetes Care 2014; 37: 2034-2054

[85] Christiansen E, Schnider S, Palmvig B et al. Intake of a diet high in trans monounsaturated fatty acids or saturated fatty acids. Effects on postprandial insulinemia and glycemia in obese patients with NIDDM. Diabetes Care 1997; 20: 881-887, EK Ib

[86] Churchill JN, Ruppe RL, Smaldone A. Use of continuous insulin infusion pumps in young children with type 1 diabetes: A systematic review. J Pediatr Health Care 2009; 23: 173-179, EK 1a

[87] Clar C, Waugh N, Thomas S. Routine hospital admission versus out-patient or home care in children at diagnosis of type 1 diabetes mellitus. Cochrane Database Syst Rev 2007; CD004 099, EK Ila-III

[88] Clarke W, Deeb LC, Jameson P et al. Diabetes care in the school and day care setting. Diabetes Care 2013; 36: S75-S79, EK IV

[89] Clarke W, Jones T, Rewers A, Dunger D, Klingensmith G]. Assessment and management of hypoglycemia in children and adolescents with diabetes. Pediatr Diabetes 2008; 9: 165-174, EK IV

[90] Clarke W, Jones T, Rewers A, Dunger D, Klingensmith G]. Assessment and management of hypoglycemia in children and adolescents with diabetes. Pediatr Diabetes 2008; 9: 165-174, EK IV

[91] Clarke W, Jones T, Rewers A, Dunger D, Klingensmith G]. Assessment and management of hypoglycemia in children and adolescents with diabetes. Pediatr Diabetes 2008; 9: 165-174, EK III
[92] Cochran JB, Walters S, Losek JD. Pediatric hyperglycemic hyperosmolar syndrome: Diagnostic difficulties and high mortality rate. Am J Emerg Med 2006; 24: 297-301, EK III

[93] Colombo C, Porzio O, Liu M et al. Seven mutations in the human insulin gene linked to permanent neonatal/infancy-onset diabetes mellitus. J Clin Invest 2008; 118: 2148-2156, EK III

[94] Colquitt ], Royle P, Waugh N. Are analogue insulins better than soluble in continuous subcutaneous insulin infusion? Results of a meta-analysis. Diabet Med 2003; 20: 863-866, EK la

[95] Colton P, Olmsted M, Daneman D et al. Disturbed eating behavior and eating disorders in preteen and early teenage girls with type 1 diabetes: A case-controlled study. Diabetes Care 2004; 27: 1654-1659, EK III

[96] Colton PA, Olmsted MP, Daneman D et al. Depression, disturbed eating behavior, and metabolic control in teenage girls with type 1 diabetes. Pediatr Diabetes 2013; 14: 372-376, EK III

[97] Copeland PM, Anderson B. Diabetes mellitus and eating disorders. Harv Rev Psychiatry 1995; 3: 36-40, EK IV

[98] Coster S, Gulliford MC, Seed PT et al. Monitoring blood glucose control in diabetes mellitus: A systematic review. Health Technol Assess 2000; 4: i-93, EK la

[99] Couch R, Jetha M, Dryden DM. Diabetes education for children with type 1 diabetes mellitus and their families, Agency for Healthcare Research and Quality (AHRQ), Rockville (MD). 2008; EK la

[100] Court JM, Cameron F], Berg-Kelly K et al. Diabetes in adolescence. Pediatr Diabetes 2008; 9: 255-262, EK IV

[101] Craig ME, Twigg SM, Donaghue KC, Cheung NW et al.Australian Type Diabetes Guidelines Expert Advisory Group. National evidence-based clinical care guidelines for type 1 diabetes in children, adolescents and adults, Australian Government Department of Health and Ageing, Canberra. 2011; EK IV

[102] Cranston I, Lomas J, Maran A et al. Restoration of hypoglycaemia awareness in patients with longduration insulin-dependent diabetes. Lancet 1994; 344: 283-287, EK III

[103] d'Emden H, Holden L, McDermott B et al. Disturbed eating behaviours and thoughts in Australian adolescents with type 1 diabetes. J Paediatr Child Health 2013; 49: E317-E323, EK III

[104] Dalla Pozza R, Bechtold S, Bonfig W et al. Age of onset of type 1 diabetes in children and carotid intima medial thickness. J Clin Endocrinol Metab 2007; 92: 2053-2057, EK IIb

[105] Danne T. Deutscher Gesundheitsbericht. Diabetes 2014 http://www. diabetesde.org/fileadmin/users/Patientenseite/PDFs_und_TEXTE/ Infomaterial/Gesundheitsbericht_2014_kl.pdf 2014, EK IIb

[106] Danne T, Aman J, Schober E et al. A comparison of postprandial and preprandial administration of insulin aspart in children and adolescents with type 1 diabetes. Diabetes Care 2003; 26: 23592364, EK Ib

[107] Danne T, Bangstad H], Deeb L et al. ISPADClinical Practice Consensus Guidelines 2014. Insulin treatment in children and adolescents with diabetes. Pediatr Diabetes 2014; 15: 115-134, EK IV

[108] Danne T, Battelino T, Jarosz-Chobot P et al. Establishing glycaemic control with continuous subcutaneous insulin infusion in children and adolescents with type 1 diabetes: Experience of the PedPump Study in 17 countries. Diabetologia 2008; 51: 1594-1601, EK III

[109] Danne T, Becker RH, Heise T et al. Pharmacokinetics, prandial glucose control, and safety of insulin glulisine in children and adolescents with type 1 diabetes. Diabetes Care 2005; 28: 2100-2105, EK Ib

[110] Danne T, Datz N, Endahl L et al. Insulin detemir is characterized by a more reproducible pharmacokinetic profile than insulin glargine in children and adolescents with type 1 diabetes: Results from a randomized, double-blind, controlled trial. Pediatr Diabetes 2008; 9: 554-560, EK Ib 
[111] Danne T, Kordonouri O. Use of technology to potentially preserve C-Peptide in type 1 diabetes mellitus. Pediatr Endocrinol Rev 2010; 7 : (Suppl 3): 396-400, EK Ib

[112] Danne T, Kordonouri O, Enders I et al. Factors influencing height and weight development in children with diabetes. Results of the Berlin Retinopathy Study. Diabetes Care 1997; 20: 281-285, EK III

[113] Danne T, Mortensen HB, Hougaard P et al. Persistent differences among centers over 3 years in glycemic control and hypoglycemia in a study of 3805 children and adolescents with type 1 diabetes from the Hvidore Study Group. Diabetes Care 2001; 24: 1342-1347, EK III

[114] Danne T, Philotheou A, Goldman D et al. A randomized trial comparing the rate of hypoglycemia-assessed using continuous glucose monitoring-in 125 preschool children with type 1 diabetes treated with insulin glargine or NPH insulin (the PRESCHOOL study). Pediatr Diabetes 2013; 14: 593-601, EK1b

[115] Danne T, Rastam J, Odendahl R et al. Parental preference of prandial insulin aspart compared with preprandial human insulin in a basal-bolus scheme with NPH insulin in a 12-wk crossover study of preschool children with type 1 diabetes. Pediatr Diabetes 2007; 8: 278-285, EK Ila

[116] Danne T, Tsioli C, Kordonouri O et al. The PILGRIM study: In silico modeling of a predictive low glucose management system and feasibility in youth with type 1 diabetes during exercise. Diabetes Technol Ther 2014; 16: 338-347, EK IIb

[117] Danne T, Weber BHartmannR et al. Long-term glycemic control has a nonlinear association to the frequency of background retinopathy in adolescents with diabetes. Follow-up of the Berlin Retinopathy Study. Diabetes Care 1994; 17: 1390-1396, EK III

[118] Davis CL, Delamater AM, Shaw KH et al. Parenting styles, regimen adherence, and glycemic control in 4- to 10-year-old children with diabetes. J Pediatr Psychol 2001; 26: 123-129, EK III

[119] de Beaufort CE, Lange K, Swift PG et al. Metabolic outcomes in young children with type 1 diabetes differ between treatment centers: The Hvidoere Study in Young Children 2009. Pediatr Diabetes 2013; 14: 422-428, EK IIb

[120] de Man SA, Andre JL, Bachmann $\mathrm{H}$ et al. Blood pressure in childhood: Pooled findings of six European studies. J Hypertens 1991; 9 : 109-114, EK IIb

[121] deWeerdt I, Visser AP, Kok G] et al. Randomized controlled multicentre evaluation of an education programme for insulin-treated diabetic patients: Effects on metabolic control, quality of life, and costs of therapy. Diabet Med 1991; 8: 338-345, EK Ib

[122] de Wit M, Winterdijk P, Aanstoot H] et al. Assessing diabetes-related quality of life of youth with type 1 diabetes in routine clinical care: The MIND Youth Questionnaire (MY-Q). Pediatr Diabetes 2012; 13: 638-646, EK IV

[123] de Wit M, Delemarre-van deWaal HA, Bokma JA et al. Monitoring and discussing health-related quality of life in adolescents with type 1 diabetes improve psychosocial well-being: A randomized controlled trial. Diabetes Care 2008; 31: 1521-1526, EK Ib

[124] de Wit M, Pouwer F, Gemke R] et al. Validation of the WHO-5WellBeing Index in adolescents with type 1 diabetes. Diabetes Care 2007; 30: 2003-2006, EK III

[125] Decourcey DD, Steil GM, Wypij D et al. Increasing use of hypertonic saline over mannitol in the treatment of symptomatic cerebral edema in pediatric diabetic ketoacidosis: An 11-year retrospective analysis of mortality* . Pediatr Crit Care Med 2013; 14: 694-700, EK III

[126] Deeb LC, Holcombe JH, Brunelle R et al. Insulin lispro lowers postprandial glucose in prepubertal children with diabetes. Pediatrics 2001; 108: 1175-1179, EK Ib

[127] Deiss D, Bolinder J, Riveline JP et al. Improved glycemic control in poorly controlled patients with type 1 diabetes using real-time continuous glucose monitoring. Diabetes Care 2006; 29: 2730-2732, EK Ib
[128] Delamater AM, Bubb J, Davis SG et al. Randomized prospective study of self-management training with newly diagnosed diabetic children. Diabetes Care 1990; 13: 492-498, EK Ib

[129] Delamater AM, de WM, McDarby V et al. ISPADClinical Practice Consensus Guidelines 2014. Psychological care of children and adolescents with type 1 diabetes. Pediatr Diabetes 2014; 15 : 232-244, EK IV

[130] Delamater AM, Jacobson AM, Anderson B et al. Psychosocial therapies in diabetes: Report of the Psychosocial Therapies Working Group. Diabetes Care 2001; 24: 1286-1292, EK la

[131] Delamater AM, Shaw KH, Applegate EB et al. Risk for metabolic control problems in minority youth with diabetes. Diabetes Care 1999; 22: 700-705, EK III

[132] Delamater AM, de Wit M, McDarby V et al. Psychological care of children and adolescents with type 1 diabetes. Pediatric Diabetes 2014; 15: 232-244

[133] Deutsche Gesellschaft für Ernährung (DGE), Österreichische Gesellschaft für Ernährung (ÖGE), Schweizerische Gesellschaft für Ernährungsforschung (SGE). (eds.) Referenzwerte für die Nährstoffzufuhr. 2. Auflage (ed.). Bonn: 2015, EK IV

[134] Deutsche Gesellschaft für Ernährung (DGE), Österreichische Gesellschaft für Ernährung (ÖGE), Schweizerische Gesellschaft für Ernährungsforschung (SGE), Schweizerische Vereinigung für Ernährung (SVE). Referenzwerte für die Nährstoffzufuhr, Neuer Umschau Buchverl., Neustadt/Weinstraße. 2008; EK IV

[135] Deutsche Gesellschaft für Kinder- und Jugendpsychiatrie, Psychosomatik und Psychotherapie (DGKJP). Behandlung von depressiven Störungen bei Kindern und Jugendlichen. Evidenz- und konsensbasierte Leitlinie (S3) .Langfassung, Stand: 01.07.2013 http://www. awmf.org/uploads/tx_szleitlinien/028 - 043I_S3_Depressive_ St\%C3\%B6rungen_bei_Kindern_Jugendlichen_2013 - 07.pdf 2013; EK IV

[136] Deutsche Gesellschaft für pädiatrische Rehabilitation und Prävention. Leitlinie Rehabilitation Diabetes mellitus im Kindes- und Jugendalter. http://www.awmf.org/uploads/tx_szleitlinien/070 - 003k_S2_Diabetes_mellitus_stationaere_Rehabilitation.pdf 2007

[137] Deutsche Gesellschaft für Psychiatrie, Psychotherapie und Nervenheilkunde (DGPPN), Bundesärztekammer (BÄK), Kassenärztliche Bundesvereinigung (KBV), Arbeitsgemeinschaft der Wissenschaftlichen Medizinischen Fachgesellschaften (AWMF). S3-Leitlinie/ Nationale VersorgungsLeitlinie Unipolare Depression - Langfassung, 1. Auflage. Version 5 http://doi.org/10.6101/AZQ/000 239 2009; EK IV

[138] Deutsche Hochdruckliga, Deutsche Hypertoniegesellschaft. Leitlinien zur Behandlung der arteriellen Hypertonie, DHL, Heidelberg. . 2008;

[139] Deutsche Rentenversicherung Bund. Rahmenkonzept zur medizinischen Rehabilitation in der gesetzlichen Rentenversicherung. $3^{\text {rd }}$ ed. Deutsche Rentenversicherung Bund; Berlin: 2009

[140] Diabetes Control and Complications Trial Research Group. Epidemiology of severe hypoglycemia in the diabetes control and complications trial. The DCCT Research Group.Am J Med 1991; 90: 450-459, EK III

[141] Diabetes Control and Complications Trial Research Group. Effect of intensive diabetes treatment on the development and progression of long-term complications in adolescents with insulin-dependent diabetes mellitus: Diabetes Control and Complications Trial. J Pediatr 1994; 125: 177-188, EK Ib

[142] Diabetes Control and Complications Trial Research Group. The relationship of glycemic exposure (HbA1c) to the risk of development and progression of retinopathy in the diabetes control and complications trial. Diabetes 1995; 44: 968-983, EK Ib

[143] Diabetes Control and Complications Trial Research Group. The absence of a glycemic threshold for the development of long-term complications: The perspective of the Diabetes Control and Complications Trial. Diabetes 1996; 45: 1289-1298 
[144] Diabetes Prevention Trial-Type 1 Diabetes Study Group. Effects of insulin in relatives of patients with type 1 diabetes mellitus. $N$ Engl J Med 2002; 346: 1685-1691, EK Ib

[145] Dobson L, Hattersley AT, Tiley $S$ et al. Clinical improvement in cystic fibrosis with early insulin treatment. Arch Dis Child 2002; 87: 430-431

[146] Dodson PM, Beevers M, Hallworth R et al. Sodium restriction and blood pressure in hypertensive type II diabetics: Randomised blind controlled and crossover studies of moderate sodium restriction and sodium supplementation. BMJ 1989; 298: 227-230, EK Ib

[147] Doherty FM, Calam R, Sanders MR. Positive parenting program (triple P) for families of adolescents with type 1 diabetes: A randomized controlled trial of self-directed teen triple P. J Pediatr Psychol 2013; 38: 846-858, EK Ib

[148] Donaghue KC, Chiarelli F, Trotta D et al. ISPADclinical practice consensus guidelines 2006 - 2007. Microvascular and macrovascular complications. Pediatr Diabetes 2007; 8: 163-170, EK III

[149] Donaghue KC, Chiarelli F, Trotta D et al. ISPADclinical practice consensus guidelines 2006 - 2007. Microvascular and macrovascular complications. Pediatr Diabetes 2007; 8: 163-170, EK IIb

[150] Donaghue KC, Chiarelli F, Trotta D et al. ISPADclinical practice consensus guidelines 2006 - 2007. Microvascular and macrovascular complications. Pediatr Diabetes 2007; 8: 163-170, EK IV

[151] Donaghue KC, Chiarelli F, Trotta D et al. ISPADclinical practice consensus guidelines 2006 - 2007. Microvascular and macrovascular complications. Pediatr Diabetes 2007; 8: 163-170

[152] Donaghue KC, Craig ME, Chan AK et al. Prevalence of diabetes complications 6 years after diagnosis in an incident cohort of childhood diabetes. Diabet Med 2005; 22: 711-718, EK IIb-III

[153] Donaghue KC, Wadwa RP, Dimeglio LA et al. ISPADClinical Practice Consensus Guidelines 2014. Microvascular and macrovascular complications in children and adolescents. Pediatr Diabetes 2014; 15 : (Suppl 20): 257-269, EK IV

[154] Doolan A, Donaghue K, Fairchild J et al. Use of HLA typing in diagnosing celiac disease in patients with type 1 diabetes. Diabetes Care 2005; 28: 806-809, EK Ila

[155] Dost A, Klinkert C, Kapellen T et al. Arterial hypertension determined by ambulatory blood pressure profiles: Contribution to microalbuminuria risk in a multicenter investigation in 2105 children and adolescents with type 1 diabetes. Diabetes Care 2008; 31: 720-725

[156] Dunger DB, Sperling MA, Acerini CL et al. ESPE/LWPES consensus statement on diabetic ketoacidosis in children and adolescents. Arch Dis Child 2004; 89: 188-194, EK IV

[157] Edge JA, Jakes RW, Roy Y et al. The UK case-control study of cerebral oedema complicating diabetic ketoacidosis in children. Diabetologia 2006; 49: 2002-2009, EK II

[158] Edghill E, Flanagan SE, Patch AM et al. Insulin mutation screening in 1044 patients with diabetes: Mutations in the INS gene are a common cause of neonatal diabetes but a rare cause of diabetes diagnosed in childhood or adulthood. Diabetes 2008; 57: 1034-1042, EK III

[159] Ehehalt S, Blumenstock G, Willasch AM et al. Continuous rise in incidence of childhood Type 1 diabetes in Germany. Diabet Med 2008; 25: 755-757, EK III

[160] Ehehalt S, Dietz K, Willasch AM et al. Prediction model for the incidence and prevalence of type 1 diabetes in childhood and adolescence: Eevidence for a cohort-dependent increase within the next two decades in Germany. Pediatr Diabetes 2012; 13: 15-20, EK III

[161] Ehehalt S, Gauger N, Blumenstock $G$ et al. Hemoglobin A1c is a reliable criterion for diagnosing type 1 diabetes in childhood and adolescence. Pediatr Diabetes 2010; 11: 446-449
[162] Ellard S, Bellanne-Chantelot C, Hattersley AT. Best practice guidelines for the molecular genetic diagnosis of maturityonset diabetes of the young. Diabetologia 2008; 51: 546-553, EK III

[163] Ellard S, Flanagan SE, Girard CA et al. Permanent neonatal diabetes caused by dominant, recessive, or compound heterozygous SUR1 mutations with opposite functional effects. Am J Hum Genet 2007; 81: 375-382

[164] Ellert U, Brettschneider AK, Ravens-Sieberer U. Gesundheitsbezogene Lebensqualität bei Kindern und Jugendlichen in Deutschland. Bundesgesundheitsblatt Gesundheitsforschung Gesundheitsschutz 2014; 57: 798-806, EK IIb

[165] Ellis D, Naar-King S, Templin T et al. Multisystemic therapy for adolescents with poorly controlled type 1 diabetes: Reduced diabetic ketoacidosis admissions and related costs over 24 months. Diabetes Care 2008; 31: 1746-1747, EK Ib

[166] Ellis DA, Naar-King S, Chen X et al. Multisystemic therapy compared to telephone support for youth with poorly controlled diabetes: Findings from a randomized controlled trial. Ann BehavMed 2012; 44: 207-215, EK Ib

[167] Ellis SE, Speroff T, Dittus RS et al. Diabetes patient education: A metaanalysis and meta-regression. Patient Educ Couns 2004; 52: 97-105, EK Ib

[168] Eppens MC, Craig ME, Jones TW et al. Type 2 diabetes in youth from the Western Pacific region: Glycaemic control, diabetes care and complications. Curr Med Res Opin 2006; 22: 1013-1020, EK III

[169] Erhart M, Holling H, Bettge $S$ et al. Der Kinder- und Jugendgesundheitssurvey (KiGGS): Risiken und Ressourcen für die psychische Entwicklung von Kindern und Jugendlichen. Bundesgesundheitsblatt Gesundheitsforschung Gesundheitsschutz 2007; 50: 800-809, EK III

[170] European Medicines Agency (EMA). Outcome of review of new safety data on insulin glargine. http://www.ema.europa. eu/docs/en_GB/ document_library/Medicine_QA/2013/05/WC500143 823.pdf 2013;

[171] European Society of Cardiology. Leitlinien für dasManagement der arteriellen Hypertonie. ESC Pocket Guideline. http://leitlinien. dgk. org/files/2014_Pocket-Leitlinien_Arterielle_Hypertonie. pdf 2013

[172] Fagot-Campagna A, Narayan KM, Imperatore G. Type 2 diabetes in children. BMJ 2001; 322: 377-378, EK III

[173] Felber J, Aust D, Baas S et al. Ergebnisse einer S2k-Konsensuskonferenz der Deutschen Gesellschaft für Gastroenterologie, Verdauungsund Stoffwechselerkrankungen (DGVS) gemeinsam mit der Deutschen Zöliakie-Gesellschaft (DZG) zur Zöliakie, Weizenallergie und Weizensensitivität. Z Gastroenterol 2014; 52: 711-743, EK IV

[174] Feldt-Rasmussen B, Mathiesen ER, Jensen T et al. Effect of improvedmetabolic control on loss of kidney function in type 1 (insulin-dependent) diabetic patients: An update of the Steno studies. Diabetologia 1991; 34: 164-170

[175] Fendler W, Baranowska Al, Mianowska B et al. Three-year comparison of subcutaneous insulin pump treatment with multi-daily injections on HbA1c, its variability and hospital burden of children with type 1 diabetes. Acta Diabetol 2012; 49: 363-370, EK IIb

[176] Ficociello LH, Perkins BA, Silva KH et al. Krolewski AS. Determinants of progression from microalbuminuria to proteinuria in patients who have type 1 diabetes and are treated with angiotensin-converting enzyme inhibitors. Clin J Am Soc Nephrol 2007; 2: 461-469, EK IIb

[177] Fiordalisi I, NovotnyWE Holbert D et al. An 18-yr prospective study of pediatric diabetic ketoacidosis: An approach to minimizing the risk of brain herniation during treatment. Pediatr Diabetes 2007; 8: 142-149, EK III

[178] Flanagan SE, Edghill EL, Gloyn AL et al. Mutations in KCNJ11, which encodes Kir6.2, are a common cause of diabetes diagnosed in the first 6 months of life, with the phenotype determined by genotype. Diabetologia 2006; 49: 1190-1197, EK IIb-III 
[179] Flanagan SE, Patch AM, Mackay D] et al. Mutations in ATP-sensitive $\mathrm{K}+$ channel genes cause transient neonatal diabetes and permanent diabetes in childhood or adulthood. Diabetes 2007; 56: 1930-1937, EK IIb-III

[180] Forsander G, Persson B, Sundelin ] et al. Metabolic control in children with insulin-dependent diabetes mellitus $5 \mathrm{y}$ after diagnosis. Early detection of patients at risk for poor metabolic control. Acta Paediatr 1998; 87: 857-864, EK III

[181] Forsander GA, Sundelin J, Persson B. Influence of the initial management regimen and family social situation on glycemic control and medical care in children with type I diabetes mellitus. Acta Paediatr 2000; 89: 1462-1468, EK Ila

[182] Franklin B, Liu J, Ginsberg-Fellner F. Cerebral edema and ophthalmoplegia reversed by mannitol in a new case of insulin-dependent diabetes mellitus. Pediatrics 1982; 69: 87-90, EK III

[183] Fröhlich C, Hermann T, Koch S et al. Indikationen für eine stationäre Rehabilitation von Kindern und Jugendlichen mit Typ-1-Diabetes eine bundesweite "DPV-Wiss"-Analyse. Diabet Stoffw 2008; 93, EK III

[184] Fröhlich-Reiterer EE, Hofer S, Kaspers S et al. Screening frequency for celiac disease and autoimmune thyroiditis in children and adolescents with type 1 diabetes mellitus-data from a German/Austrian multicentre survey. Pediatr Diabetes 2008; 9: 546-553, EK III

[185] Fröhlich-Reiterer EE, Kaspers S, Hofer S et al. Anthropometry, metabolic control, and follow-up in children and adolescents with type 1 diabetes mellitus and biopsy-proven celiac disease. J Pediatr 2011; 158: 589-593, EK III

[186] Gaede P, Vedel P, Parving HH et al. 21 Intensified multifactorial intervention in patients with type 2 diabetes mellitus and microalbuminuria: The Steno type 2 randomised study. Lancet 1999; 353: 617-622

[187] Gage H, Hampson S, Skinner TC et al. Educational and psychosocial programmes for adolescents with diabetes: Approaches, outcomes and cost-effectiveness. Patient Educ Couns 2004; 53: 333-346, EK Ib

[188] Gale EA, Bingley PJ, Emmett CL et al. European Nicotinamide Diabetes Intervention Trial (ENDIT): A randomized controlled trial of intervention before the onset of type 1 diabetes. Lancet 2004; 363: 925-931, EK Ib

[189] Gale EA, Gillespie KM. Diabetes and gender. Diabetologia 2001; 44: 3-15, EK IIb

[190] Garg A. High-monounsaturated-fat diets for patients with diabetes mellitus: A meta-analysis. Am J Clin Nutr 1998; 67: 577S-582S, EK la

[191] Garin I, Edghill EL, Akerman I et al. Recessive mutations in the INS gene result in neonatal diabetes through reduced insulin biosynthesis. Proc Natl Acad Sci USA 2010; 107: 3105-3110

[192] Gaudieri PA, Chen R, Greer TF et al. Cognitive function in children with type 1 diabetes: A meta-analysis. Diabetes Care 2008; 31: 1892-1897, EK Ib

[193] Gayes LA, Steele RG. A meta-analysis of motivational interviewing interventions for pediatric health behavior change. J Consult Clin Psychol 2014; 82: 521-535, EK la

[194] Genuth S, Alberti KG, Bennett P et al. Follow-up report on the diagnosis of diabetes mellitus. Diabetes Care 2003; 26: 3160-3167

[195] Gerstl EM, Rabl W, Rosenbauer ] et al. Metabolic control as reflected by $\mathrm{HbA1} \mathrm{c}$ in children, adolescents and young adults with type- 1 diabetes mellitus: Combined longitudinal analysis including 27035 patients from 207 centers in Germany and Austria during the last decade. Eur J Pediatr 2008; 167: 447-453, EK IIb-III

[196] Gheissari A, Javanmard SH, Shirzadi R et al. The effects of blocking Angiotensin receptors on early stages of diabetic nephropathy. Int J Prev Med 2012; 3: 477-482

[197] Giacco R, Parillo M, Rivellese AA et al. Long-term dietary treatment with increased amounts of fiber-rich low-glycemic index natural foods improves blood glucose control and reduces the number of hypoglycemic events in type 1 diabetic patients. Diabetes Care 2000; 23: 1461-1466, EK Ib
[198] Glaser N, Barnett P, McCaslin I et al. Risk factors for cerebral edema in children with diabetic ketoacidosis. The Pediatric Emergency Medicine Collaborative Research Committee of the American Academy of Pediatrics. N Engl J Med 2001; 344: 264-269, EK III

[199] Glaser NS, Wootton-Gorges SL, Buonocore MH et al. Frequency of sub-clinical cerebral edema in children with diabetic ketoacidosis. Pediatr Diabetes 2006; 7: 75-80, EK III

[200] Glasgow RE, Fisher EB, Anderson B] et al. Behavioral science in diabetes. Contributions and opportunities. Diabetes Care 1999; 22: 832-843, EK la

[201] Gloyn AL, Diatloff-Zito C, Edghill EL et al. KCNJ11 activating mutations are associated with developmental delay, epilepsy and neonatal diabetes syndrome and other neurological features. Eur J Hum Genet 2006; 14: 824-830

[202] Gloyn AL, Pearson ER, Antcliff JF et al. Activating mutations in the gene encoding the ATP-sensitive potassium-channel subunit Kir6.2 and permanent neonatal diabetes. N Engl J Med 2004; 350 : 1838-1849, EK III

[203] Goebel-Fabbri AE, Fikkan J, Franko DL et al. Insulin restriction and associated morbidity and mortality inwomen with type 1 diabetes. Diabetes Care 2008; 31: 415-419, EK IIb

[204] Golicki DT, Golicka D, Groele L et al. Continuous Glucose Monitoring System in children with type 1 diabetes mellitus: A systematic review and meta-analysis. Diabetologia 2008; 51: 233-240, EK la

[205] Gong M, Simaite D, Kuhnen P et al. Two novel GATA6 mutations cause childhood-onset diabetes mellitus, pancreas malformation and congenital heart disease. Horm Res Paediatr 2013; 79: 250-256

[206] Gottschalk M, Danne T, Vlajnic A et al. Glimepiride versus metformin asmonotherapy in pediatric patients with type 2 diabetes: A randomized, single-blind comparative study. Diabetes Care 2007; 30: 790-794, EK Ib

[207] Grabert M, Schweiggert F, Holl RW. A framework for diabetes documentation and quality management in Germany: 10 years of experience with DPV. Comput Methods Programs Biomed 2002; 69: 115-121, EK III

[208] Graham DJ, Staffa JA, Shatin D et al. Incidence of hospitalized rhabdomyolysis in patients treated with lipid-lowering drugs. JAMA 2004; 292: 2585-2590, EK III

[209] Green SM, Rothrock SG, Ho JD et al. Failure of adjunctive bicarbonate to improve outcome in severe pediatric diabetic ketoacidosis. Ann Emerg Med 1998; 31: 41-48

[210] Grey M, Boland EA, Davidson M et al. Coping skills training for youth with diabetes mellitus has long-lasting effects on metabolic control and quality of life. J Pediatr 2000; 137: 107-113, EK Ib

[211] Grey M, Cameron ME, Lipman TH et al. Psychosocial status of children with diabetes in the first 2 years after diagnosis. Diabetes Care 1995; 18: 1330-1336, EK IIb

[212] Grey M, Cameron ME, Lipman TH et al. Psychosocial status of children with diabetes in the first 2 years after diagnosis. Diabetes Care 1995; 18: 1330-1336, EK III

[213] Grey M, Whittemore R, Jaser $S$ et al. Effects of coping skills training in school-age children with type 1 diabetes. Res Nurs Health 2009; 32: 405-418, EK Ib

[214] Grey M, Whittemore R, Jeon S et al. Internet psycho-education programs improve outcomes in youth with type 1 diabetes. Diabetes Care 2013; 36: 2475-2482, EK Ib

[215] Grulich-Henn J, Wagner V, Thon A et al. Entities and frequency of neonatal diabetes: Data from the diabetes documentation and quality management system (DPV). Diabet Med 2010; 27: 709-712, EK III

[216] Haas L, Maryniuk M, Beck J et al. National standards for diabetes self-management education and support. Diabetes Care 2014; 37: (Suppl 1): S144-S153, EK IV 
[217] Hale P], Crase J, Nattrass M. Metabolic effects of bicarbonate in the treatment of diabetic ketoacidosis. Br Med J (Clin Res Ed 1984; 289: 1035-1038, EK Ila

[218] Hammes HP, Kerner W, Hofer S et al. Diabetic retinopathy in type 1 diabetes-a contemporary analysis of 8784 patients. Diabetologia 2011; 54: 1977-1984

[219] Hampson SE, Skinner TC, Hart J et al. Effects of educational and psychosocial interventions for adolescents with diabetes mellitus: A systematic review. Health Technol Assess 2001; 5: 1-79, EK la

[220] Hanas R, Adolfsson P. Insulin pumps in pediatric routine care improve long-term metabolic control without increasing the risk of hypoglycemia. Pediatr Diabetes 2006; 7: 25-31, EK III

[221] Hanas R, Lindgren F, Lindblad B. Diabetic ketoacidosis and cerebral oedema in Sweden-a 2-year paediatric population study. Diabet Med 2007; 24: 1080-1085, EK III

[222] Hanberger L, Ludvigsson J, Nordfeldt S. Use of a web 2.0 portal to improve education and communication in young patients with families: Randomized controlled trial. J Med Internet Res 2013; 15: e175, EK Ib

[223] Hansen D, Brock-Jacobsen B, Lund E et al. Clinical benefit of a gluten-free diet in type 1 diabetic children with screeningdetected celiac disease: A population-based screening study with 2 years follow-up. Diabetes Care 2006; 29: 2452-2456, EK Ila

[224] Harris MA, Freeman KA, Beers M. Family therapy for adolescents with poorly controlled diabetes: Initial test of clinical significance. J Pediatr Psychol 2009; 34: 1097-1107, EK IIb

[225] Hattersley A, Bruining J, Shield J et al. ISPADClinical Practice Consensus Guidelines 2006 - 2007. The diagnosis and management of monogenic diabetes in children. Pediatr Diabetes 2006; 7: 352-360, EK IV

[226] Haugstvedt A, Wentzel-Larsen T, Graue M et al. Fear of hypoglycaemia in mothers and fathers of children with Type 1 diabetes is associated with poor glycaemic control and parental emotional distress: A population-based study. Diabet Med 2010; 27: 72-78, EK Ilb

[227] Haugstvedt A, Wentzel-Larsen T, Rokne B et al. Perceived family burden and emotional distress: Similarities and differences between mothers and fathers of children with type 1 diabetes in a populationbased study. Pediatr Diabetes 2011; 12: 107-114, EK IIb

[228] Hecker W, Bartus B, Heinze E et al. Stoffwechseleinstellung des Diabetes mellitus Typ 1 bei Kindern und Jugendlichen deutscher und ausländischer Herkunft. Diabet Stoffw 1998; 5: 177-180, EK III

[229] Hecker W, Grabert M, Holl RW. Quality of paediatric IDDMcare in Germany: A multicentre analysis. German Paediatric Diabetology Group. J Pediatr Endocrinol Metab 1999; 12: 31-38, EK III

[230] Helgeson VS, Reynolds KA, Becker D et al. Relations of behavioral autonomy to health outcomes among emerging adults with and without type 1 diabetes. J Pediatr Psychol 2014; 39: 1126-1137, EK III

[231] Helgeson VS, Siminerio L, Escobar O et al. Predictors of metabolic control among adolescents with diabetes: A 4-year longitudinal study. J Pediatr Psychol 2009; 34: 254-270, EK III

[232] Helgeson VS, Snyder PR, Escobar O et al. Comparison of adolescents with and without diabetes on indices of psychosocial functioning for three years. J Pediatr Psychol 2007; 32: 794-806, EK IIb

[233] Helgeson VS, Viccaro L, Becker D et al. Diet of adolescents with and without diabetes: Trading candy for potato chips? Diabetes Care 2006; 29: 982-987, EK III

[234] Hellems MA, Clarke WL. Safe at school: A Virginia experience. Diabetes Care 2007; 30: 1396-1398, EK III

[235] Hermann JM, Hammes HP, Rami-Merhar B et al. HbA1c variability as an independent risk factor for diabetic retinopathy in type 1 diabetes: A German/Austrian multicenter analysis on 35891 patients. PLoS One 2014; 9: e91 137
[236] Herzer M, Hood KK. Anxiety symptoms in adolescents with type 1 diabetes: Association with blood glucose monitoring and glycemic control. J Pediatr Psychol 2010; 35: 415-425, EK III

[237] Herzer M, Vesco A, Ingerski LM et al. Explaining the family conflictglycemic control link through psychological variables in adolescents with type 1 diabetes. J Behav Med 2011; 34: 268-274, EK III

[238] Hieftje K, Edelman E], Camenga DR et al. Electronic media-based health interventions promoting behavior change in youth: A systematic review. JAMA Pediatr 2013; 167: 574-580, EK la

[239] Hill ID, Dirks MH, Liptak GS et al. Guideline for the diagnosis and treatment of celiac disease in children: Recommendations of the North American Society for Pediatric Gastroenterology, Hepatology and Nutrition. J Pediatr Gastroenterol Nutr 2005; 40: 1-19, EK III

[240] Hilliard ME, Herzer M, Dolan LM et al. Psychological screening in adolescents with type 1 diabetes predicts outcomes one year later. Diabetes Res Clin Pract 2011; 94: 39-44, EK III

[241] Hirsch IB, Abelseth J, Bode BW et al. Sensor-augmented insulin pump therapy: Results of the first randomized treat-to-target study. Diabetes Technol Ther 2008; 10: 377-383, EK Ib

[242] Hoey H. Psychosocial factors are associated with metabolic control in adolescents: Research from the Hvidoere Study Group on Childhood Diabetes. Pediatr Diabetes 2009; 10: (Suppl 13): 9-14, EK IIb

[243] Holl RW, Grabert M. Versorgung von Kindern und Jugendlichen mit Diabetes - Entwicklungen der letzten 19 Jahre. In Deutsche Diabetes-Hilfe, editor.: Gesundheitsbericht Diabetes 2015; 2015: S. 128-138, EK III

[244] Holl RW, Grabert M, Heinze E et al. Age at onset and long-term metabolic control affect height in type-1 diabetes mellitus. Eur J Pediatr 1998; 157: 972-977, EK III

[245] Holl RW, Heinze E. Dawn- oder Somogyi-Phänomen? Hohe morgendliche Nüchternblutzuckerwerte bei jugendlichen Typ-1-Diabetikern. Dtsch Med Wochenschr 1992; 117: 1503-1507, EK III

[246] Holl RW, Lang GE, Grabert M et al. Diabetic retinopathy in pediatric patients with type- 1 diabetes: effect of diabetes duration, prepubertal and pubertal onset of diabetes, and metabolic control. J Pediatr 1998; 132: 790-794, EK III

[247] Holl RW, Pavlovic M, Heinze E et al. Circadian blood pressure during the early course of type 1 diabetes. Analysis of 1011 ambulatory blood pressure recordings in 354 adolescents and young adults. Diabetes Care 1999; 22: 1151-1157, EK III

[248] Holl RW, Wolf A, Heinze E et al. Nicht-immunologisch bedingte Formen des Diabetes mellitus bei Kindern und Jugendlichen. Monatsschr Kinderheilkd 1997; 145: 159-176, EK III

[249] Hölling H, Erhar tM, Ravens-Sieberer $U$ et al. Verhaltensauffälligkeiten bei Kindern und Jugendlichen. Erste Ergebnisse aus dem Kinder- und Jugendgesundheitssurvey (KiGGS). Bundesgesundheitsblatt Gesundheitsforschung Gesundheitsschutz 2007; 50: 784-793, EK III

[250] Hölling H, Schlack R. Essstörungen im Kindes- und Jugendalter. Erste Ergebnisse aus dem Kinder- und Jugendgesundheitssurvey (KiGGS). Bundesgesundheitsblatt Gesundheitsforschung Gesundheitsschutz 2007; 50: 794-799, EK III

[251] Hölling H, Schlack R, Petermann F et al. Psychische Auffälligkeiten und psychosoziale Beeinträchtigungen bei Kindern und Jugendlichen im Alter von 3 bis 17 Jahren in Deutschland - Prävalenz und zeitliche Trends zu 2 Erhebungszeitpunkten (2003 - 2006 und 2009 - 2012). Bundesgesundheitsblatt Gesundheitsforschung Gesundheitsschutz 2014; 57: 807-819, EK IIb

[252] Holman RR, Paul SK, Bethel MA et al. 10- year follow-up of intensive glucose control in type 2 diabetes. N Engl J Med 2008; 359 : 1577-1589, EK Ib

[253] Holmes CS, Chen R, Streisand R et al. Predictors of youth diabetes care behaviors and metabolic control: A structural equation modeling approach. J Pediatr Psychol 2006; 31: 770-784, EK III 
[254] Holterhus PM, Odendahl R, Oesingmann S et al. Classification of distinct baseline insulin infusion patterns in children and adolescents with type 1 diabetes on continuous subcutaneous insulin infusion therapy. Diabetes Care 2007; 30: 568-573, EK IIb-III

[255] Hommel E, Olsen B, Battelino T et al. Impact of continuous glucose monitoring on quality of life, treatment satisfaction, and use of medical care resources: Analyses from the SWITCH study. Acta Diabetol 2014; 51: 845-851, EK Ib

[256] Hood KK, Huestis S, Maher A et al. Depressive symptoms in children and adolescents with type 1 diabetes: Association with diabetesspecific characteristics. Diabetes Care 2006; 29: 1389-1391, EK III

[257] Hood KK, Rausch JR, Dolan LM. Depressive symptoms predict change in glycemic control in adolescents with type 1 diabetes: Rates, magnitude, and moderators of change. Pediatr Diabetes 2011; 12: 718-723, EK III

[258] Hood KK, Rohan JM, Peterson CM et al. Interventions with adherence-promoting components in pediatric type 1 diabetes: Metaanalysis of their impact on glycemic control. Diabetes Care 2010; 33: 1658-1664, EK la

[259] Horsch A, McManus F, Kennedy P et al. Anxiety, depressive, and posttraumatic stress symptoms in mothers of children with type 1 diabetes. J Trauma Stress 2007; 20: 881-891, EK III

[260] Hovorka R, Elleri D, Thabit $\mathrm{H}$ et al. Overnight closed-loop insulin delivery in young people with type 1 diabetes: A free-living, randomized clinical trial. Diabetes Care 2014; 37: 1204-1211, EK Ib

[261] Howell WH, McNamara D], Tosca MA et al. Plasma lipid and lipoprotein responses to dietary fat and cholesterol: A meta-analysis. Am J Clin Nutr 1997; 65: 1747-1764, EK la

[262] Hu FB, Cho E, Rexrode KM et al. Fish and long-chain omega-3 fatty acid intake and risk of coronary heart disease and total mortality in diabetic women. Circulation 2003; 107: 1852-1857, EK III

[263] Hürter A, Otten A. Familien mit diabetischen Kindern und Jugendlichen: Psychische und soziale Probleme und der Wunsch nach psychologischer Hilfe im Vergleich mit anderen chronischen Erkrankungen,. In Roth R, Borkenstein M. editors. Psychosoziale Aspekte in der Betreuung von Kindern und Jugendlichen mit Diabetes, Karger, Basel; 1991: S. 150-159, EK III

[264] Hürter P, Bürger W, Schober E et al. Qualitätssicherung in der Pädiatrischen Diabetologie. Monatsschr Kinderheilkd 1995; 143: 1146-1149, EK IV

[265] Hürter P, von Schütz W, Lange K. Kinder und Jugendliche mit Diabetes. Medizinischer und psychologischer Ratgeber für Eltern. 3. Aufl. (ed.) Springer; Berlin: 2012

[266] Husby S, Koletzko S, Korponay-Szabo IR, Mearin ML, Phillips A, Shamir R, Troncone R, Giersiepen K, Branski D, Catassi C, Lelgeman M, Maki M, Ribes-Koninckx C, Ventura A, Zimmer KP. European Society for Pediatric Gastroenterology, Hepatology, and Nutrition guidelines for the diagnosis of coeliac disease. J Pediatr Gastroenterol Nutr 2012; 54: 136-160, EK IV

[267] Hutchinson A, Mclntosh A, Peters J et al. Effectiveness of screening and monitoring tests for diabetic retinopathy-a systematic review. Diabet Med 2000; 17: 495-506, EK Ila

[268] Icks A, Razum O, Rosenbauer J et al. Lower frequency of insulin pump treatment in children and adolescents of Turkish background with type 1 diabetes: Analysis of 21497 patients in Germany. Diabetes Technol Ther 2012; 14: 1105-1109, EK IIb

[269] Icks A, Rosenbauer ], Holl RW et al. Increased hospitalization with longer distance from treatment centre in diabetic paediatric patients in Germany. Diabetologia 2001; 44: 1068-1069, EK IIb-III

[270] Icks A, Rosenbauer ], Strassburger K et al. Persistent social disparities in the risk of hospital admission of paediatric diabetic patients in Germany-prospective data from 1277 diabetic children and adolescents. Diabet Med 2007; 24: 440-442, EK III
[271] Ingerski LM, Laffel L, Drotar D et al. Correlates of glycemic control and quality of life outcomes in adolescents with type 1 diabetes. Pediatr Diabetes 2010; 11: 563-571, EK III

[272] Institut für Qualität und Wirtschaftlichkeit im Gesundheitswesen (IQWiG): Kurzwirksame Insulinanaloga zur Behandlung des Diabetes mellitus Typ 1. Abschlussbericht. Auftrag A05-02 Version 1.0. Stand: 30.03.2007 IQWiG, Köln : 2007

[273] International Society for Pediatric and Adolescent Diabetes (ISPAD). Clinical Practice Consensus Guidelines 2014. Pediatr Diabetes 2014; 15: $1-290$

[274] Irgens HU, Molnes ], Johansson BB et al. Prevalence of monogenic diabetes in the population-based Norwegian Childhood Diabetes Registry. Diabetologia 2013; 56: 1512-1519

[275] Jacobson AM, Hauser ST, Lavori P et al. Family environment and glycemic control: A four-year prospective study of children and adolescents with insulin-dependent diabetes mellitus. Psychosom Med 1994; 56: 401-409, EK III

[276] Jacobson AM, Hauser ST, Willett J et al. Consequences of irregular versus continuous medical follow-up in children and adolescents with insulin-dependent diabetes mellitus. J Pediatr 1997; 131: 727-733, EK III

[277] Jacobson AM, Musen G, Ryan CM et al. Longterm effect of diabetes and its treatment on cognitive function. N Engl J Med 2007; 356: 1842-1852, EK Ib

[278] Janner M, Knill SE, Diem P et al. Persistent microalbuminuria in adolescents with type I (insulindependent) diabetes mellitus is associated to early rather than late puberty. Results of a prospective longitudinal study. Eur J Pediatr 1994; 153: 403-408, EK IIb

[279] Jefferies C, Solomon M, Perlman K et al. Continuous glucose monitoring in adolescents with cystic fibrosis. J Pediatr 2005; 147: 396-398, EK IIb

[280] Jefferson IG, Swift PG, Skinner TC et al. Diabetes services in the UK: Third national survey confirms continuing deficiencies. Arch Dis Child 2003; 88: 53-56, EK III

[281] Jeitler K, Horvath K, Berghold A et al. Continuous subcutaneous insulin infusion versus multiple daily insulin injections in patients with diabetes mellitus: Systematic review and meta-analysis. Diabetologia 2008; 51: 941-951 la

[282] Johansson S, Irgens H, Chudasama KK, Molnes ], Aerts ], Roque FS, Jonassen I, Levy S, Lima K, Knappskog PM, Bell GI, Molven A, Njolstad PR. Exome sequencing and genetic testing for MODY. PLoS One 2012; 7: e38 050

[283] Jones CA, Leese GP, Kerr S et al. Development and progression of microalbuminuria in a clinic sample of patients with insulin dependent diabetes mellitus. Arch Dis Child 1998; 78: 518-523, EK III

[284] Jones KL, Arslanian S, Peterokova VA et al. Effect of metformin in pediatric patients with type 2 diabetes: A randomized controlled trial. Diabetes Care 2002; 25: 89-94, EK Ib

[285] Kalk W], Osler C, Constable J et al. Influence of dietary protein on glomerular filtration and urinary albumin excretion in insulin-dependent diabetes. Am J Clin Nutr 1992; 56: 169-173, EK III

[286] Kapellen T, Vogel C, Telleis D et al. Treatment of diabetic ketoacidosis (DKA) with 2 different regimens regarding fluid substitution and insulin dosage ( 0.025 vs. 0.1 units $/ \mathrm{kg} / \mathrm{h}$ ). Exp Clin Endocrinol Diabetes 2012; 120: 273-276, EK III

[287] Kapellen TM, Klinkert C, Heidtmann B et al. Insulin pump treatment in children and adolescents with type 1 diabetes: Experiences of the German working group for insulin pump treatment in pediatric patients. Postgrad Med 2010; 122: 98-105

[288] Karges B, Muche R, Knerr I et al. Levothyroxine in euthyroid autoimmune thyroiditis and type 1 diabetes: A randomized, controlled trial. J Clin Endocrinol Metab 2007; 92: 1647-1652, EK Ib 
[289] Karges B, Rosenbauer ], Holterhus PM et al. Hospital admission for diabetic ketoacidosis or severe hypoglycemia in 31330 young patients with type 1 diabetes. Eur J Endocrinol 2015; 173: 341-350, EK III

[290] Karges B, Rosenbauer J, Kapellen T et al. Hemoglobin A1c Levels and risk of severe hypoglycemia in children and young adults with type 1 diabetes from Germany and Austria: A trend analysis in a cohort of 37539 patients between 1995 and 2012. PLoS Med 2014; 11: e1001 742, EK III

[291] Katan MB, Zock PL, Mensink RP. Dietary oils, serum lipoproteins, and coronary heart disease. Am J Clin Nutr 1995; 61: 1368S-1373S, EK la

[292] Katz ML, Volkening LK, Butler DA et al. Family-based psychoeducation and Care Ambassador intervention to improve glycemic control in youth with type 1 diabetes: A randomized trial. Pediatr Diabetes 2014; 15: 142-150, EK Ib

[293] Keane S, Gallagher A, Ackroyd S et al. Cerebral venous thrombosis during diabetic ketoacidosis. Arch Dis Child 2002; 86: 204-205, EK IV

[294] Kellerer M, Danne T. Praxis-Leitlinien der Deutschen Diabetes Gesellschaft. Diabet Stoffw 2010; 5: S107-S108

[295] Kellerer M, Siegel E., (Hrsg). Praxisleitlinien der Deutschen Diabetes Gesellschaft. Diabet Stoffw 2014; 9: S95-S228

[296] Kempf K, Rathmann W, Herder C. Impaired glucose regulation and type 2 diabetes in children and adolescents. Diabetes Metab Res Rev 2008; 24: 427-437, EK IIb-III

[297] Kiess W, Bottner A, Raile $K$ et al. Type 2 diabetes mellitus in children and adolescents: A review from a European perspective. Horm Res 2003; 59: (Suppl 1): 77-84, EK III

[298] Kilpatrick ES, Rigby AS, Atkin SL. The effect of glucose variability on the risk of microvascular complications in type 1 diabetes. Diabetes Care 2006; 29: 1486-1490, EK Ila

[299] Kintzel R, Holl R, Haberland H et al. Die diabetische Ketoazidose bei Erkrankungsbeginn im Kindes- und Jugendalter in der Bundesrepublik. Diab Stoffw 2003; 12: 8-12, EK IIb

[300] Klupa T, Kowalska I, Wyka K et al. Mutations in the ABCC8 gene are associated with a variable clinical phenotype. Clin Endocrinol (Oxf) 2008, EK III

[301] Knerr I, Dost A, Lepler R et al. Tracking and prediction of arterial blood pressure from childhood to young adulthood in 868 patients with type 1 diabetes: A multicenter longitudinal survey in Germany and Austria. Diabetes Care 2008; 31: 726-727, EK IIb-III

[302] Knowler WC, Barrett-Connor E, Fowler SE et al. Reduction in the incidence of type 2 diabetes with lifestyle intervention or metformin. N Engl J Med 2002; 346: 393-403, EK Ib

[303] Koch C, Rainisio M, Madessani U et al. Presence of cystic fibrosisrelated diabetes mellitus is tightly linked to poor lung function in patients with cystic fibrosis: Data from the European Epidemiologic Registry of Cystic Fibrosis. Pediatr Pulmonol 2001; 32: 343-350, EK III

[304] Koletzko B, Broekaert I, Kreuder J et al. Leitlinien zur Diagnostik und Therapie von Hyperlipidämien bei Kindern und Jugendlichen, APS,. 2007

[305] Kongkaew C, Jampachaisri K, Chaturongkul CA, Scholfield CN.. Depression and adherence to treatment in diabetic children and adolescents: A systematic review and meta-analysis of observational studies. Eur J Pediatr 2014; 173: 203-212, EK la

[306] Konrad K, Scheuing N, Badenhoop K et al. Cystic fibrosisrelated diabetes compared with type 1 and type 2 diabetes in adults. Diabetes Metab Res Rev 2013; 29: 568-575

[307] Konrad K, Thon A, Fritsch M et al. Comparison of cystic fibrosis-related diabetes with type 1 diabetes based on a German/Austrian Pediatric Diabetes Registry. Diabetes Care 2013; 36: 879-886, EK III
[308] Kordonouri O, Biester T, Schnell K et al. Lipoatrophy in children with type 1 diabetes: An increasing incidence? J Diabetes Sci Technol 2015; 9: 206-208, EK III

[309] Kordonouri O, Charpentier N, Hartmann R. GADA positivity at onset of type 1 diabetes is a risk factor for the development of autoimmune thyroiditis. Pediatr Diabetes 2011; 12: 31-33, EK IIb

[310] Kordonouri O, Deiss D, Danne T et al. Predictivity of thyroid autoantibodies for the development of thyroid disorders in children and adolescents with Type 1 diabetes. Diabet Med 2002; 19: 518-521, EK III

[311] Kordonouri O, Hartmann R, Lauterborn R et al. Age-specific advantages of continuous subcutaneous insulin infusion as compared with multiple daily injections in pediatric patients: One-year follow-up comparison by matched-pair analysis. Diabetes Care 2006; 29: 133-134, EK Ila

[312] Kordonouri O, Klingensmith G, Knip M et al. ISPADClinical Practice Consensus Guidelines 2014. Other complications and diabetes-associated conditions in children and adolescents. Pediatr Diabetes 2014; 15: 270-278, EK IV

[313] Kordonouri O, Klinghammer A, Lang EB et al. Thyroid autoimmunity in children and adolescents with type 1 diabetes: A multicenter survey. Diabetes Care 2002; 25: 1346-1350, EK III

[314] Kordonouri O, Maguire AM, Knip M et al. Other complications and associated conditions, In: International Diabetes Federation (IDF), editor.: Global IDF/ISPADGuideline for Diabetes in Childhood and Adolescence Brussels. 2011; S. 124-128, EK IV

[315] Kordonouri O, Maguire AM, Knip M et al. ISPADClinical Practice Consensus Guidelines 2006 - 2007. Other complications and associated conditions. Pediatr Diabetes 2007; 8: 171-176

[316] Kordonouri O, Maguire AM, Knip M et al. ISPADClinical Practice Consensus Guidelines 2006 - 2007. Other complications and associated conditions. Pediatr Diabetes 2007; 8: 171-176 EK IV

[317] Korhonen T, Huttunen JK, Aro A et al. A controlled trial on the effects of patient education in the treatment of insulin-dependent diabetes. Diabetes Care 1983; 6: 256-261 EK Ib

[318] Koster JC, Cadario F, Peruzzi C et al. The G53D mutation in Kir6.2 (KCNJ11) is associated with neonatal diabetes and motor dysfunction in adulthood that is improvedwith sulfonylurea therapy. J Clin Endocrinol Metab 2008; 93: 1054-1061, EK III

[319] Kovacs M, Feinberg TL, Paulauskas S et al. Initial coping responses and psychosocial characteristics of children with insulin-dependent diabetes mellitus. J Pediatr 1985; 106: 827-834 EK III

[320] Kovacs M, Ho V, Pollock MH. Criterion and predictive validity of the diagnosis of adjustment disorder: A prospective study of youths with new-onset insulin-dependent diabetes mellitus. Am J Psychiatry 1995; 152: 523-528, EK III

[321] Kovacs M, lyengar S, Goldston D et al. Psychological functioning among mothers of children with insulin-dependent diabetes mellitus: A longitudinal study. J Consult Clin Psychol 1990; 58: 189-195, EK III

[322] Kromeyer-Hauschild K, Wabitsch M, Kunze D et al. Perzentile für den Body-mass-Index für das Kindes- und Jugendalter unter Heranziehung verschiedener deutscher Stichproben. Monatsschr Kinderheilkd 2001; 149: 807-818, EK III

[323] Kulzer B, Albus C, Herpertz S et al. Psychosoziales und Diabetes (Teil 1). S2-Leitlinie Psychosoziales und Diabetes - Langfassung. Diabet Stoffw 2013; 8: 198-242, EK IV

[324] Kulzer B, Albus C, Herpertz S et al. Psychosoziales und Diabetes (Teil 2). S2-Leitlinie Psychosoziales und Diabetes - Langfassung. Diabet Stoffw 2013; 8: 292-324, EK IV

[325] Kurth BM, Schaffrath RA. Die Verbreitung von Übergewicht und Adipositas bei Kindern und Jugendlichen in Deutschland. Ergebnisse des bundesweiten Kinder- und Jugendgesundheitssurveys (KiGGS). Bundesgesundheitsblatt Gesundheitsforschung Gesundheitsschutz 2007; 50: 736-743, EK III 
[326] I'Allemand D, Wiegand S, Reinehr T et al. Cardiovascular risk in 26008 European overweight children as established by a multicenter database. Obesity.Silver Spring; 2008: 16: 1672-1679, EK IIb-III

[327] Laffel LM, Vangsness L, Connell A et al. Impact of ambulatory, family-focused teamwork intervention on glycemic control in youth with type 1 diabetes. J Pediatr 2003; 142: 409-416, EK IIb

[328] Laffel LM, Vangsness L, Connell A et al. Impact of ambulatory, family-focused teamwork intervention on glycemic control in youth with type 1 diabetes. J Pediatr 2003; 142: 409-416, EK Ila

[329] Laffel LM, Wentzell K, Loughlin C et al. Sick day management using blood 3-hydroxybutyrate (3-OHB) compared with urine ketone monitoring reduces hospital visits in young people with T1DM: A randomized clinical trial. Diabet Med 2006; 23: 278-284, EK Ib

[330] Laguna TA, Nathan BM, Moran A. Managing diabetes in cystic fibrosis. Diabetes Obes Metab 2010; 12: 858-864, EK IV

[331] Lampeter EF, Klinghammer A, Scherbaum WA et al. The Deutsche Nicotinamide Intervention Study: An attempt to prevent type 1 diabetes. DENIS Group. Diabetes 1998; 47: 980-984, EK Ib

[332] Landolt MA, Ribi K, Laimbacher ] et al. Posttraumatic stress disorder in parents of children with newly diagnosed type 1 diabetes. J Pediatr Psychol 2002; 27: 647-652, EK III

[333] Lange K, Burger W, Holl R et al. Diabetes bei Jugendlichen: Ein Schulungsprogramm, Kirchheim, Mainz. 2009;

[334] Lange K, Danne T, Kordonouri O et al. Diabetesmanifestation im Kindesalter: Alltagsbelastungen und berufliche Entwicklung der Eltern. Dtsch Med Wochenschr 2004; 129: 1130-1134, EK III

[335] Lange K, Hildebrandt S, Danne T. Diabetesversorgung in der Pädiatrie - Leitlinien und Realität. Ergebnisse zweier bundesweiter Umfragen von 1998 und 2003. Dtsch Arztebl 2007; 104: A-2121-2126, EK III

[336] Lange K, Hürter P. Effekte einer strukturierten Diabetesschulung für Jugendliche auf Stoffwechsel, Wissen, Wohlbefinden und Selbständigkeit - Ergebnisse einer multizentrischen Studie. Diabet Stoffw 1998; 7: 62, EK IIb

[337] Lange K, Kinderling S, Hürter P. Eine multizentrische Studie zur Prozess- und Ergebnisqualität eines strukturierten Schulungsprogramms. Diabet Stoffw 2001; 10: 59-65, EK III

[338] Lange K, Kleine T, Danne T. Initialschulung für Eltern von Kindern mit Diabetes: Aufwand und Effekte bei Kindern und Eltern. Dtsch MedWochenschr 2011; 136: 1106-1110, EK IIb

[339] Lange K, Klotmann S, Sassmann $\mathrm{H}$ et al. A pediatric diabetes toolbox for creating centres of reference. Pediatr Diabetes 2012; 13: 49-61, EK IV

[340] Lange K, Matthaei S, Lueg A et al. Life chances (“Lebenschancen”) of young adults with onset of type 1 diabetes during Childhood. Pediatric Diabetes 2013; 14: 35, EK IIb

[341] Lange K, Remus K, Bläsig S et al. Diabetes bei Kindern: Ein Behandlungs- und Schulungsprogramm, Kirchheim, Mainz. 2013

[342] Lange K, Stachow U, Kurzinsky R, Holl R, Hürter P.. Pädiatrische Betreuung von Kindern und Jugendlichen mit Diabetes. Eine bundesweite Umfrage der Arbeitsgemeinschaft für Pädiatrische Diabetologie in der Deutschen Diabetes-Gesellschaft und der Deutschen Gesellschaft für Kinderheilkunde und Jugendmedizin. Diabet Stoffw 2002; 11: 14-22, EK III

[343] Lange K, Swift P, Pankowska E et al. Diabetes education in children and adolescents. Pediatric Diabetes 2014; 15: 77-85, EK IV

[344] Lange K, Swift P, Pankowska E et al. ISPADClinical Practice Consensus Guidelines 2014. Diabetes education in children and adolescents. Pediatr Diabetes 2014; 15: (Suppl 20): 77-85, EK IV

[345] Lange K, von Schütz W, Neu A et al. Diabetesschulung. Schulungsprogramme und Curricula für Kinder, Jugendliche mit Typ 1 Diabetes, deren Eltern und andere Betreuer. Pabst Lengerich: 2014;
[346] Lango Allen H, Flanagan SE, Shaw-Smith C et al. GATA6 haploinsufficiency causes pancreatic agenesis in humans. Nat Genet 2012; 44: 20-22

[347] Lanng S, Thorsteinsson B, Lund-Andersen C et al. Diabetes mellitus in Danish cystic fibrosis patients: Prevalence and late diabetic complications. Acta Paediatr 1994; 83: 72-77, EK IIb-III

[348] Lanng S, Thorsteinsson B, Nerup J et al. Influence of the development of diabetes mellitus on clinical status in patients with cystic fibrosis. Eur J Pediatr 1992; 151: 684-687, EK III

[349] Laron Z, Galatzer A, Amir S et al. A multidisciplinary, comprehensive, ambulatory treatment scheme for diabetes mellitus in children. Diabetes Care 1979; 2: 342-348, EK III

[350] Larsson K, Carlsson A, Cederwall E et al. Annual screening detects celiac disease in children with type 1 diabetes. Pediatr Diabetes 2008; 9: 354-359, EK IIlb

[351] Lawrence JM, Standiford DA, Loots B et al. Prevalence and correlates of depressed mood among youth with diabetes: The SEARCH for Diabetes in Youth study. Pediatrics 2006; 117: 1348-1358, EK IIb

[352] Lawrence JM, Standiford DA, Loots B et al. Prevalence and correlates of depressed mood among youth with diabetes: The SEARCH for Diabetes in Youth study. Pediatrics 2006; 117: 1348-1358, EK IV

[353] Lazarus ], Brown RS, Daumerie C et al. 2014 European thyroid association guidelines for the management of subclinical hypothyroidism in pregnancy and in children. Eur Thyroid J 2014; 3: 76-94, EK IV

[354] Lehmkuhl HD, Storch EA, Cammarata C et al. Telehealth behavior therapy for the management of type 1 diabetes in adolescents. J Diabetes Sci Technol 2010; 4: 199-208, EK Ib

[355] Levene LS, McNally PG, Fraser RC et al. What characteristics are associated with screening positive for microalbuminuria in patients with diabetes in the community? Pract Diabet Int 2004; 21: 287-292, EK III

[356] Levin DL. Cerebral edema in diabetic ketoacidosis. Pediatr Crit Care Med 2008; 9: 320-329, EK III

[357] Levy-Marchal C, Patterson CC, Green A. Geographical variation of presentation at diagnosis of type I diabetes in children: The EURODIAB study. European and Dibetes. Diabetologia 2001; 44: (Suppl 3): B75-B80, EK III

[358] Levy-Shraga Y, Elisha NBen-AmiM et al. Glycemic control and clinic attendance of emerging adults with type 1 diabetes at a transition care clinic. Acta Diabetol 2015, EK III

[359] Lewis HM, Renaula TL, Garioch J] et al. Protective effect of gluten-free diet against development of lymphoma in dermatitis herpetiformis. Br J Dermatol 1996; 135: 363-367, EK Ila

[360] Liberatore RR Jr., Barbosa SF, Alkimin MG et al. Is immunity in diabetic patients influencing the susceptibility to infections? Immunoglobulins, complement and phagocytic function in children and adolescents with type 1 diabetes mellitus. Pediatr Diabetes 2005; 6: 206-212, EK III

[361] Lin A, Northam EA, Rankins D et al. Neuropsychological profiles of young people with type 1 diabetes $12 \mathrm{yr}$ after disease onset. Pediatr Diabetes 2010; 11: 235-243, EK IIb

[362] Lind M, Svensson AM, Kosiborod M et al. Glycemic control and excess mortality in type 1 diabetes. N Engl J Med 2014; 371: 1972-1982, EK III

[363] Lindstrom C, Aman J, Norberg AL. Parental burnout in relation to sociodemographic, psychosocial and personality factors as well as disease duration and glycaemic control in children with Type 1 diabetes mellitus. Acta Paediatr 2011; 100: 1011-1017, EK III

[364] Lindstrom J, Ilanne-Parikka P, Peltonen $\mathrm{M}$ et al. Sustained reduction in the incidence of type 2 diabetes by lifestyle intervention: Follow-up of the Finnish Diabetes Prevention Study. Lancet 2006; 368: 1673-1679, EK Ib 
[365] Liu C, Wu D, Zheng X et al. Efficacy and safety of metformin for patients with type 1 diabetes mellitus: A meta-analysis. Diabetes Technol Ther 2015; 17: 142-148, EK 1b

[366] Lorini R, Klersy C, d'Annunzio G et al. Maturity-onset diabetes of the young in children with incidental hyperglycemia: A multicenter Italian study of 172 families. Diabetes Care 2009; 32: 1864-1866

[367] Lorini R, Scotta MS, Cortona L et al. Celiac disease and type I (insulin-dependent) diabetes mellitus in childhood: Follow-up study. J Diabetes Complications 1996; 10: 154-159, EK III

[368] Ludvigsson J, Bolli GB. Intensive insulin treatment in diabetic children. Diabetes Nutr Metab 2001; 14: 292-304, EK IIb

[369] Ludvigsson J, Krisky D, Casas R et al. GAD65 antigen therapy in recently diagnosed type 1 diabetes mellitus. N Engl J Med 2012; 366: 433-342

[370] Ludwig-Seibold CU, Holder M, Rami B et al. Continuous glucose monitoring in children, adolescents, and adults with type 1 diabetes mellitus: Analysis from the prospective DPV diabetes documentation and quality management system from Germany and Austria. Pediatr Diabetes 2012; 13: 12-14

[371] Ly TT, Maahs DM, Rewers A et al. ISPADClinical Practice Consensus Guidelines 2014. Assessment and management of hypoglycemia in children and adolescents with diabetes. Pediatr Diabetes 2014; 15: (Suppl 20): 180-192, EK IV

[372] Ly TT, Nicholas JA, Retterath A et al. Effect of sensor-augmented insulin pump therapy and automated insulin suspension vs standard insulin pump therapy on hypoglycemia in patients with type 1 diabetes: A randomized clinical trial. JAMA 2013; 310: 1240-1247, EK Ib

[373] Maahs DM, Calhoun P, Buckingham BA et al. A randomized trial of a home system to reduce nocturnal hypoglycemia in type 1 diabetes. Diabetes Care 2014; 37: 1885-1891, EK Ib

[374] Maahs DM, Hermann JM, DuBose SN et al. Contrasting the clinical care and outcomes of 2622 children with type 1 diabetes less than 6 years of age in the United States T1D Exchange and German/Austrian DPV registries. Diabetologia 2014; 57: 1578-1585, EK III

[375] Mann JI, De L, Hermansen I et al. Evidence-based nutritional approaches to the treatment and prevention of diabetes mellitus. Nutr Metab Cardiovasc Dis 2004; 14: 373-394

[376] Mannucci E, Rotella F, Ricca $V$ et al. Eating disorders in patients with type 1 diabetes: A meta- analysis. J Endocrinol Invest 2005; 28: 417-419, EK la

[377] Margeirsdottir HD, Larsen JR, Brunborg C et al. High prevalence of cardiovascular risk factors in children and adolescents with type 1 diabetes: A population- based study. Diabetologia 2008; 51: 554-561 IIb-III

[378] Markowitz JT, Butler DA, Volkening LK et al. Brief screening tool for disordered eating in diabetes: Internal consistency and external validity in a contemporary sample of pediatric patients with type 1 diabetes. Diabetes Care 2010; 33: 495-500, EK III

[379] Martin D, Lange K, Sima A et al. Recommendations for age-appropriate education of children and adolescents with diabetes and their parents in the European Union. Pediatr Diabetes 2012; 13: (Suppl 16): 20-28, EK IV

[380] Marzelli M], Mazaika PK, Barnea-Goraly N et al. Neuroanatomical correlates of dysglycemia in young children with type 1 diabetes. Diabetes 2014; 63: 343-353, EK III

[381] Mathiesen ER, Saurbrey N, Hommel E et al. Prevalence of microalbuminuria in children with type 1 (insulindependent) diabetes mellitus. Diabetologia 1986; 29: 640-643, EK III

[382] Matthaei S, Bierwirth R, Fritsche A et al. Medikamentöse antihyperglykämische Therapie des Diabetesmellitus Typ 2. Update der Evidenzbasierten Leitlinie der Deutschen Diabetes-Gesellschaft http://www.deutsche-diabetes-gesellschaft.de/fileadmin/Redakteur/ Leitlinien/Evidenzbasierte_Leitlinien/EBL_Dm_Typ2_Update_2008. pdf 2008
[383] Mauras N, Beck R, Xing D et al. A randomized clinical trial to assess the efficacy and safety of realtime continuous glucose monitoring in the management of type 1 diabetes in young children aged 4 to $<10$ years. Diabetes Care 2012; 35: 204-210, EK Ib

[384] McBroom LA, Enriquez M. Review of family-centered interventions to enhance the health outcomes of children with type 1 diabetes. Diabetes Educ 2009; 35: 428-438, EK la

[385] McDonald T], Ellard S. Maturity onset diabetes of the young: Identification and diagnosis. Ann Clin Biochem 2013; 50: 403-415, EK III

[386] McKnight JA, Wild SH, Lamb MJ et al. Glycaemic control of Type 1 diabetes in clinical practice early in the 21st century: An international comparison. Diabet Med 2015; 32: 1036-1050, EK IIb

[387] Meltzer LJ, Johnson SB, Prine JM et al. Disordered eating, body mass, and glycemic control in adolescents with type 1 diabetes. Diabetes Care 2001; 24: 678-682, EK III

[388] Mensink RP, Zock PL, Kester AD et al. Effects of dietary fatty acids and carbohydrates on the ratio of serum total to $\mathrm{HDL}$ cholesterol and on serum lipids and apolipoproteins: A meta-analysis of 60 controlled trials. Am J Clin Nutr 2003; 77: 1146-1155, EK la

[389] Milla CE, Warwick W], Moran A. Trends in pulmonary function in patients with cystic fibrosis correlate with the degree of glucose intolerance at baseline. Am J Respir Crit Care Med 2000; 162: 891-895, EK III

[390] Miller KM, Beck RW, Bergenstal RM et al. Evidence of a strong association between frequency of self-monitoring of blood glucose and hemoglobin A1c levels in T1D exchange clinic registry participants. Diabetes Care 2013; 36: 2009-2014, EK III

[391] Miller-Johnson S, Emery RE, Marvin RS et al. Parent-child relationships and the management of insulin-dependent diabetes mellitus. J Consult Clin Psychol 1994; 62: 603-610, EK III

[392] Misso ML, Egberts KJ, Page M et al. Continuous subcutaneous insulin infusion (CSII) versus multiple insulin injections for type 1 diabetes mellitus. Cochrane Database Syst Rev 2010; CD005 103, la

[393] Mlynarski W, Tarasov Al, Gach A et al. Sulfonylurea improves CNS function in a case of intermediate DEND syndrome caused by a mutation in KCNJ11. Nat Clin Pract Neurol 2007; 3: 640-645, EK III

[394] Mohn A, Di MS, Di LR et al. The effect of subclinical hypothyroidism on metabolic control in children and adolescents with Type 1 diabetes mellitus. Diabet Med 2002; 19: 70-73, EK Ila

[395] Monetini L, Cavallo MG, Stefanini L et al. Bovine beta-casein antibodies in breast- and bottle-fed infants: Their relevance in Type 1 diabetes. Diabetes Metab Res Rev 2001; 17: 51-54, EK III

[396] Moore WV, Donaldson DL, Chonko AM et al. Ambulatory blood pressure in type I diabetes mellitus. Comparison to presence of incipient nephropathy in adolescents and young adults. Diabetes 1992; 41: 1035-41, EK IIb

[397] Morris LR, Murphy MB, Kitabchi AE. Bicarbonate therapy in severe diabetic ketoacidosis. Ann Intern Med 1986; 105: 836-840

[398] Mortensen HB, Hougaard P, Ibsen KK et al. Relationship between blood pressure and urinary albumin excretion rate in young Danish type 1 diabetic patients: Comparison to non-diabetic children. Danish Study Group of Diabetes in Childhood. Diabet Med 1994; 11: 155-161, EK Ila

[399] Mortensen HB, Lindholm A, Olsen BS et al. Rapid appearance and onset of action of insulin aspart in paediatric subjects with type 1 diabetes. Eur J Pediatr 2000; 159: 483-488, EK Ib

[400] Mortensen HB, Robertson KJ, Aanstoot HJ et al. Insulin management and metabolic control of type 1 diabetes mellitus in childhood and adolescence in 18 countries. Hvidore Study Group on Childhood Diabetes. Diabet Med 1998; 15: 752-759, EK III 
[401] Muir AB, Quisling RG, Yang MC et al. Cerebral edema in childhood diabetic ketoacidosis: Natural history, radiographic findings, and early identification. Diabetes Care 2004; 27: 1541-1546, EK IIb-III

[402] Mulvaney SA, Rothman RL, Osborn CY et al. Self-management problem solving for adolescents with type 1 diabetes: Intervention processes associated with an Internet program. Patient Educ Couns 2011; 85: 140-142 EK IIb

[403] Mulvaney SA, Rothman RL, Wallston KA et al. Dietrich MS. An internet-based program to improve self-management in adolescents with type 1 diabetes. Diabetes Care 2010; 33: 602-604, EK IIb

[404] Murphy HR, Rayman G, Skinner TC. Psycho-educational interventions for children and young people with Type 1 diabetes. Diabet Med 2006; 23: 935-943, EK la

[405] Murphy HR, Rayman G, Skinner TC. Psycho-educational interventions for children and young people with Type 1 diabetes. Diabet Med 2006; 23: 935-943, EK Ib

[406] Murphy R, Ellard S, Hattersley AT. Clinical implications of a molecular genetic classification of monogenic beta-cell diabetes. Nat Clin Pract Endocrinol Metab 2008; 4: 200-213, EK IV

[407] Musen G, Jacobson AM, Ryan CM et al. Impact of diabetes and its treatment on cognitive function among adolescents who participated in the Diabetes Control and Complications Trial. Diabetes Care 2008; 31: 1933-1938, EK Ib

[408] Naar-King S, Idalski A, Ellis D et al. Gender differences in adherence and metabolic control in urban youth with poorly controlled type 1 diabetes: The mediating role of mental health symptoms. J Pediatr Psychol 2006; 31: 793-802, EK III

[409] Nadeau K], Klingensmith G, Zeitler P. Type 2 diabetes in children is frequently associated with elevated alanine aminotransferase. J Pediatr Gastroenterol Nutr 2005; 41: 94-98, EK IIb-III

[410] Naguib JM, Kulinskaya E, Lomax CL et al. Neuro-cognitive performance in children with type 1 diabetes-A meta- analysis. J Pediatr Psychol 2009; 34: 271-282, EK Ib

[411] Nahata L. Insulin therapy in pediatric patients with type I diabetes: Continuous subcutaneous insulin infusion versus multiple daily injections. Clin Pediatr (Phila) 2006; 45: 503-508, EK la

[412] Nakhla M, Daneman D, Frank M et al. Translating transition: A critical Review of the diabetes literature. J Pediatr Endocrinol Metab 2008; 21: 507-516, EK III

[413] Nallasamy K, Jayashree M, Singhi S et al. Low-dose vs. standard-dose insulin in pediatric diabetic ketoacidosis: A randomized clinical trial. JAMA Pediatr 2014; 168: 999-1005, EK Ib

[414] Nansel TR, lannotti RJ, Liu A. Clinic-integrated behavioral intervention for families of youth with type 1 diabetes: Randomized clinical trial. Pediatrics 2012; 129: e866-e873, EK Ib

[415] Nansel TR, lannotti RJ, Simons-Morton BG et al. Diabetes personal trainer outcomes: Short-term and 1-year outcomes of a diabetes personal trainer intervention among youth with type 1 diabetes. Diabetes Care 2007; 30: 2471-2477, EK IIb

[416] Nansel TR, lannotti R], Simons-Morton BG et al. Long-term maintenance of treatment outcomes: Diabetes personal trainer intervention for youth with type 1 diabetes. Diabetes Care 2009; 32: 807-809, EK IIb

[417] Nardi L, Zucchini S, D'Alberton F et al. Quality of life, psychological adjustment and metabolic control in youths with type 1 diabetes: A study with self- and parent-report questionnaires. Pediatr Diabetes 2008; 9: 496-503, EK III

[418] Nathan DM, Cleary PA, Backlund JY et al. Intensive diabetes treatment and cardiovascular disease in patients with type 1 diabetes. N Engl J Med 2005; 353: 2643-2653, EK Ib

[419] Neu A, Ehehalt S, Bendas A et al. Incidence of childhood type 1 diabetes in Germany: A nationwide survey over a period of ten years. Pediatric Diabetes 2013; 14: 119
[420] Neu A, Ehehalt S, Feldhahn LM et al. Diabeteshäufigkeit bei Kindern und Jugendlichen in Deutschland - 20 Jahre Diabetes-Inzidenzregister Baden- Württemberg. Diabetologie 2008; 309-313

[421] Neu A, Ehehalt S, Willasch A et al. Rising incidence of type 1 diabetes in Germany: 12-year trend analysis in children $0-14$ years of age. Diabetes Care 2001; 24: 785-786, EK Ila

[422] Neu A, Feldhahn L, Ehehalt S et al. Prevalence of type 2 diabetes and MODY in children and adolescents. A state-wide study in BadenWuerttemberg (Germany). Pediatr Diabetes 2005; 6: 27-28 EK III

[423] Neu A, Hofer SE, Karges B et al. Ketoacidosis at diabetes onset is still frequent in children and adolescents: A multicenter analysis of 14 664 patients from 106 institutions. Diabetes Care 2009; 32: 1647-1648, EK III

[424] Neu A, Lange K, Lösch-Binder M et al. Diabetes - na und? DVD mit drei Informationsfilmen für Lehrer/innen von Kindern mit Diabetes zum Einsatz im Unterricht, = Arbeitsgemeinschaft pädiatrische Diabetologie (AGPD) 2011

[425] Neu A, Losch-Binder M, Ehehalt S et al. Follow-up of adolescents with diabetes after transition from paediatric to adult care: Results of a 10-year prospective study. Exp Clin Endocrinol Diabetes 2010; 118: 353-355, EK III

[426] Neu A, Willasch A, Ehehalt S et al. Ketoacidosis at onset of type 1 diabetes mellitus in children-frequency and clinical presentation. Pediatr Diabetes 2003; 4: 77-81, EK III

[427] Neuhauser H, Schienkiewitz A, Schaffrath RA et al. Robert Koch Institut (RKI): Referenzperzentile für anthropometrische Maßzahlen und Blutdruck aus der Studie zur Gesundheit von Kindern und Jugendlichen in Deutschland (KiGGS). 2. erweiterte Auflage, RKI; Berlin: 2013

[428] Neuhauser HK, Thamm M, Ellert $U$ et al. Blood pressure percentiles by age and height from nonoverweight children and adolescents in Germany. Pediatrics 2011; 127: e978-e988

[429] Nichols PJ, Norris SL. A systematic literature reviewof the effectiveness of diabetes education of school personnel. Diabetes Educ 2002; 28: 405-414, EK III

[430] Nieuwesteeg A, Pouwer F, van der Kamp R et al. Quality of life of children with type 1 diabetes: A systematic review. Curr Diabetes Rev 2012; 8: 434-443, EK III

[431] Nimri R, Muller I, Atlas E et al. MD-Logic overnight control for 6 weeks of home use in patients with type 1 diabetes: Randomized crossover trial. Diabetes Care 2014; 37: 3025-3032, EK Ib

[432] Nimri R, Weintrob $\mathrm{N}$, Benzaquen $\mathrm{H}$ et al. Insulin pump therapy in youth with type 1 diabetes: A retrospective paired study. Pediatrics 2006; 117: 2126-2131, EK IIb-III

[433] Nordfeldt S, Ludvigsson J. Adverse events in intensively treated children and adolescents with type 1 diabetes. Acta Paediatr 1999; 88: 1184-1193, EK IIb

[434] Nordfeldt S, Ludvigsson J. Fear and other disturbances of severe hypoglycaemia in children and adolescents with type 1 diabetes mellitus. J Pediatr Endocrinol Metab 2005; 18: 83-91, EK III

[435] Nordwall M, Hyllienmark L, Ludvigsson J. Early diabetic complications in a population of young patients with type 1 diabetes mellitus despite intensive treatment. J Pediatr Endocrinol Metab 2006; 19: 45-54, EK III

[436] Norris JM, Barriga K, Klingensmith G et al. Timing of initial cereal exposure in infancy and risk of islet autoimmunity. JAMA 2003; 290: 1713-1720, EK III

[437] Northam EA, Anderson PJ, Werther GA et al. Neuropsychological complications of IDDMin children 2 years after disease onset. Diabetes Care 1998; 21: 379-384, EK III

[438] Northam EA, Matthews LK, Anderson PJ et al. Psychiatric morbidity and health outcome in Type 1 diabetes-perspectives from a prospective longitudinal study. Diabet Med 2005; 22: 152-157, EK III 
[439] Northam EA, Todd S, Cameron FJ. Interventions to promote optimal health outcomes in children with Type 1 diabetes-are they effective? Diabet Med 2006; 23: 113-121, EK la-III

[440] Nousia-Arvanitakis S, Galli-Tsinopoulou A, Karamouzis M. Insulin improves clinical status of patients with cystic-fibrosis-related diabetes mellitus. Acta Paediatr 2001; 90: 515-519, EK III

[441] O'Hayon BE, Cummings EA, Daneman D et al. Does dietary protein intake correlate with markers suggestive of early diabetic nephropathy in children and adolescents with Type 1 diabetes mellitus? Diabet Med 2000; 17: 708-712, EK III

[442] O'Riordan SM, Robinson PD, Donaghue KC et al. Managementof cystic fibrosis-related diabetes. Pediatr Diabetes 2008; 9: 338-344

[443] Okuda Y, Adrogue HJ, Field JB et al. Counterproductive effects of sodium bicarbonate in diabetic ketoacidosis. J Clin Endocrinol Metab 1996; 81: 314-320

[444] Olmsted MP, Daneman D, Rydall AC et al. The effects of psychoeducation on disturbed eating attitudes and behavior in young women with type 1 diabetes mellitus. Int J Eat Disord 2002; 32: 230-239, EK Ib

[445] Overby NC, Margeirsdottir HD, Brunborg C et al. hl- Jorgensen K. The influence of dietary intake and meal pattern on blood glucose control in children and adolescents using intensive insulin treatment. Diabetologia 2007; 50: 2044-2051 EK Ilb

[446] Overstreet S, Goins ], Chen RS et al. Family environment and the interrelation of family structure, child behavior, and metabolic control for children with diabetes. J Pediatr Psychol 1995; 20: 435-447, EK Ila

[447] Pankowska E, Blazik M, Dziechciarz P et al. Continuous subcutaneous insulin infusion vs. multiple daily injections in children with type 1 diabetes: A systematic review and meta-analysis of randomized control trials. Pediatr Diabetes 2008, EK la

[448] Pankowska E, Szypowska A, Lipka M et al. Sustained metabolic control and low rates of severe hypoglycaemic episodes in preschool diabetic children treated with continuous subcutaneous insulin infusion. Acta Paediatr 2007; 96: 881-884, EK IIb-III

[449] Pattison HM, Moledina S, Barrett TG. The relationship between parental perceptions of diabetes and glycaemic control. Arch Dis Child 2006; 91: 487-490, EK III

[450] Pavlovic MD, Milenkovic T, Dinic M et al. The prevalence of cutaneous manifestations in young patients with type 1 diabetes. Diabetes Care 2007; 30: 1964-1967, EK III

[451] Pearson ER, Flechtner I, Njolstad PR et al. Switching from insulin to oral sulfonylureas in patients with diabetes due to Kir6.2 mutations. N Engl J Med 2006; 355: 467-477, EK III

[452] Pearson ER, Liddell WG, Shepherd M et al. Sensitivity to sulphonylureas in patients with hepatocyte nuclear factor-1alpha gene mutations: Evidence for pharmacogenetics in diabetes. Diabet Med 2000; 17: 543-545, EK III

[453] Perantie DC, Lim A, Wu J et al. Effects of prior hypoglycemia and hyperglycemia on cognition in children with type 1 diabetes mellitus. Pediatr Diabetes 2008; 9: 87-95, EK III

[454] Persson S, Dahlquist G, Gerdtham UG et al. Impact of childhoodonset type 1 diabetes on schooling: A population- based register study. Diabetologia 2013; 56: 1254-1262, EK IIb

[455] Peterson DB, Lambert J, Gerring $S$ et al. Sucrose in the diet of diabetic patients-just another carbohydrate? Diabetologia 1986; 29: 216-220, EK Ib

[456] Peyrot M, Rubin RR. Behavioral and psychosocial interventions in diabetes: A conceptual review. Diabetes Care 2007; 30: 2433-2440, EK Ib

[457] Peyrot M, Rubin RR. Treatment satisfaction in the sensoraugmented pump therapy for A1C reduction 3 (STAR 3) trial. Diabet Med 2013; 30: 464-467, EK Ib
[458] Phillip M, BattelinoT Atlas E et al. Nocturnal glucose control with an artificial pancreas at a diabetes camp. N Engl J Med 2013; 368: 824-833, EK Ib

[459] Phillip M, Battelino T, Rodriguez $\mathrm{H}$ et al. Use of insulin pump therapy in the pediatric age-group: consensus statement from the European Society for Paediatric Endocrinology, the Lawson Wilkins Pediatric Endocrine Society, and the International Society for Pediatric and Adolescent Diabetes, endorsed by the American Diabetes Association and the European Association for the Study of Diabetes. Diabetes Care 2007; 30: 1653-1662

[460] Philotheou A, Arslanian S, Blatniczky L et al. Comparable efficacy and safety of insulin glulisine and insulin lispro when given as part of a Basal-bolus insulin regimen in a 26-week trial in pediatric patients with type 1 diabetes. Diabetes Technol Ther 2011; 13: 327-334

[461] Pihoker C, Forsander G, Fantahun B et al. ISPADClinical Practice Consensus Guidelines 2014. The delivery of ambulatory diabetes care to children and adolescents with diabetes. Pediatr Diabetes 2014; 15: (Suppl 20): 86-101, EK IV

[462] Plank J, Siebenhofer A, Berghold A et al. Systematic review and meta-analysis of shortacting insulin analogues in patients with diabetes mellitus. Arch Intern Med 2005; 165: 1337-1344, EK la

[463] Plener PL, Molz E, Berger G et al. Depression, metabolic control, and antidepressant medication in young patients with type 1 diabetes. Pediatr Diabetes 2015; 16: 58-66, EK IIb

[464] Polak M, Dechaume A, Cave $\mathrm{H}$ et al. Heterozygous missense mutations in the insulin gene are linked to permanent diabetes appearing in the neonatal period or in early infancy: A report from the French ND (Neonatal Diabetes) Study Group. Diabetes 2008; 57 : 1115-1119, EK III

[465] Povlsen L, Olsen B, Ladelund S. Diabetes in children and adolescents from ethnic minorities: Barriers to education, treatment and good metabolic control. J Adv Nurs 2005; 50: 576-582, EK III

[466] Powers SW, Byars KC, Mitchell MJ et al. Parent report of mealtime behavior and parenting stress in young children with type 1 diabetes and in healthy control subjects. Diabetes Care 2002; 25: 313-318, EK III

[467] Puttha R, Cooke D, Subbarayan A et al. Low dose ( 0.05 units $/ \mathrm{kg} / \mathrm{h})$ is comparable with standard dose $(0.1 \mathrm{units} / \mathrm{kg} / \mathrm{h})$ intravenous insulin infusion for the initial treatment of diabetic ketoacidosis in children with type 1 diabetes-an observational study. Pediatr Diabetes 2010; 11: 12-17, EK III

[468] Radetti G, Paganini C, Gentili L et al. Frequency of Hashimoto's thyroiditis in children with type 1 diabetes mellitus. Acta Diabetol 1995; 32: 121-124, EK III

[469] Raile K, Galler A, Hofer S et al. Diabetic nephropathy in 27805 children, adolescents, and adults with type 1 diabetes: Effect of diabetes duration, A1C, hypertension, dyslipidemia, diabetes onset, and sex. Diabetes Care 2007; 30: 2523-2528, EK IIb-III

[470] Raile K, Klopocki E, Holder M et al. Expanded clinical spectrum in hepatocyte nuclear factor 1b-maturity-onset diabetes of the young. J Clin Endocrinol Metab 2009; 94: 2658-2664, EK IV

[471] Raile K, O'Connell M, Galler A et al. Diabetes caused by insulin gene (INS) deletion: Clinical characteristics of homozygous and heterozygous individuals. Eur J Endocrinol 2011; 165: 255-260

[472] Raile K, Schober E, Konrad K et al. Treatment of young patients with HNF1A mutations (HNF1A-MODY). Diabet Med 2015; 32: 526-530

[473] Rattay P, von der LE, Lampert T. Gesundheit von Kindern und Jugendlichen in Eineltern-, Stief- und Kernfamilien. Bundesgesundheitsblatt Gesundheitsforschung Gesundheitsschutz 2014; 57 : 860-868, EK IIb

[474] Reid G], Dubow EF, Carey TC et al. Contribution of coping to medical adjustment and treatment responsibility among children and adolescents with diabetes. J Dev Behav Pediatr 1994; 15: 327-335, EK III 
[475] Reinehr T, Schober E, Roth CL et al. Type 2 diabetes in children and adolescents in a 2-year follow-up: Insufficient adherence to diabetes centers. Horm Res 2008; 69: 107-113, EK III

[476] Reinehr T, Temmesfeld M, Kersting $M$ et al. Four-year follow-up of children and adolescents participating in an obesity intervention program. Int J Obes (Lond) 2007; 31: 1074-1077, EK III

[477] Renders CM, Valk GD, Griffin S] et al. Interventions to improve the management of diabetes in primary care, outpatient, and community settings: a systematic review. Diabetes Care 2001; 24: 1821-1833, EK la

[478] Rewers A, Klingensmith G, Davis C et al. Presence of diabetic ketoacidosis at diagnosis of diabetes mellitus in youth: The Search for Diabetes in Youth Study. Pediatrics 2008; 121: e1258-e1266, EK III

[479] Rewers M, Pihoker C, Donaghue K et al. Assessment and monitoring of glycemic control in children and adolescents with diabetes. Pediatr Diabetes 2007; 8: 408-418

[480] Rewers M, Pihoker C, Donaghue K et al. Assessment and monitoring of glycemic control in children and adolescents with diabetes. Pediatr Diabetes 2007; 8: 408-418, EK IV

[481] Reynolds KA, Helgeson VS. Children with diabetes compared to peers: depressed? Distressed? A meta-analytic review. Ann Behav Med 2011; 42: 29-41 EK Ib

[482] Riccardi G, Rivellese A, Pacioni D et al. Separate influence of dietary carbohydrate and fibre on the metabolic control in diabetes. Diabetologia 1984; 26: 116-421, EK Ib

[483] Richter B, Neises G. 'Human' insulin versus animal insulin in people with diabetes mellitus. Cochrane Database Syst Rev 2005; CD003 816, EK la

[484] Riddell MC, Iscoe KE. Physical activity, sport, and pediatric diabetes. Pediatr Diabetes 2006; 7: 60-70, EK IV

[485] Riley MD, Dwyer T. Microalbuminuria is positively associated with usual dietary saturated fat intake and negatively associated with usual dietary protein intake in people with insulin-dependent diabetes mellitus. Am J Clin Nutr 1998; 67: 50-57, EK III

[486] Riveline JP, Schaepelynck P, Chaillous L et al. Assessment of patient-led or physician-driven continuous glucose monitoring in patients with poorly controlled type 1 diabetes using basal-bolus insulin regimens: A 1-year multicenter study. Diabetes Care 2012; 35: 965-971, EK Ib

[487] Rivellese A, Riccardi G, Giacco A et al. Effect of dietary fibre on glucose control and serum lipoproteins in diabetic patients. Lancet 1980; 2: 447-450, EK Ib

[488] Roberts MD, Slover RH, Chase HP. Diabetic ketoacidosis with intracerebral complications. Pediatr Diabetes 2001; 2: 109-114, EK III

[489] Robertson K, Riddell MC, Guinhouya BC et al. ISPADClinical Practice Consensus Guidelines 2014. Exercise in children and adolescents with diabetes. Pediatr Diabetes 2014; 15: (Suppl 20): 203-223, EK IV

[490] Robertson KJ, Schoenle E, Gucev Z et al. Insulin detemir compared with NPH insulin in children and adolescents with Type 1 diabetes. Diabet Med 2007; 24: 27-34, EK Ib

[491] Rohrer T, Stierkorb E, Grabert M et al. Delayed menarche in young German women with type 1 diabetes mellitus: Recent results from the DPV diabetes documentation and quality management system. Eur J Pediatr 2008; 167: 793-799

[492] Rolon MA, Benali K, Munck A et al. Cystic fibrosis-related diabetes mellitus: Clinical impact of prediabetes and effects of insulin therapy. Acta Paediatr 2001; 90: 860-867, EK III

[493] Ronkainen MS, Hamalainen AM, Koskela P et al. Pregnancy induces nonimmunoglobulin insulinbinding activity in both maternal and cord blood serum. Clin Exp Immunol 2001; 124: 190-196, EK Ib

[494] Rosenbauer J, Dost A, Karges B et al. Improved metabolic control in children and adolescents with tye 1 diabetes: $A$ trend analysis using prospective multicenter data from Germany and Austria. Diabetes Care 2012; 35: 80-86, EK III
[495] Rosenbauer ], Herzig P, Giani G. Familial risk Type 1 diabetes mellitus in preschool age. Diabetologia 2003; 46: A118, EK lia

[496] Rosenbauer J, Icks A, du Prel JB, Giani G.. Populationsbasierte Daten zur Inzidenz des Typ-2-Diabetes mellitus bei Kindern und Jugendlichen in Deutschland. Monatsschr Kinderheilkd 2003; 151: 71 EK III

[497] Rosenbauer J, Icks A, Giani G. Clinical characteristics and predictors of severe ketoacidosis at onset of type 1 diabetes mellitus in children in a North Rhine-Westphalian region, Germany. J Pediatr Endocrinol Metab 2002; 15: 1137-1145, EK IIb

[498] Rosenbauer J, Icks A, Giani G. Incidence and prevalence of childhood type 1 diabetes mellitus in Germany-model-based national estimates. J Pediatr Endocrinol Metab 2002; 15: 1497-1504, EK lib

[499] Rosenbauer J, Icks AGrabertM et al. Hohe Prävalenz des Typ-1-Diabetes mellitus im Kindes- und Jugendalter in Deutschland (Abstract). Kinder- Jugendmed 2002; 2: A84 EK III

[500] Rosenbauer ], Rothe U, Bendas A et al. in cooperation with the DIARY Group Baden- Wuerttemberg tCDRiStGPSUEatD-SI. National prevalence estimates of childhood type 1 diabetes in Germany. Pediatric Diabetes 2013; 14: 119, EK III

[501] Rosenbloom AL, Schatz DA, Krischer JP et al. Therapeutic controversy: prevention and treatment of diabetes in children. J Clin Endocrinol Metab 2000; 85: 494-522 EK IV

[502] Rubio-Cabezas O, Klupa T, Malecki MT. Permanent neonatal diabetes mellitus-the importance of diabetes differential diagnosis in neonates and infants. Eur J Clin Invest 2011; 41: 323-333

[503] Rutledge KS, Chase HP, Klingensmith G] et al. Effectiveness of postprandial Humalog in toddlers with diabetes. Pediatrics 1997; 100: 968-972, EK Ila

[504] Sacks FM, Svetkey LP, Vollmer WM et al. Effects on blood pressure of reduced dietary sodium and the Dietary Approaches to Stop Hypertension (DASH) diet. DASH-Sodium Collaborative Research Group. N Engl J Med 2001; 344: 3-10, EK Ib

[505] Sagen JV, Raeder H, Hathout E et al. Permanent neonatal diabetes due to mutations in KCNJ11 encoding Kir6.2: Patient characteristics and initial response to sulfonylurea therapy. Diabetes 2004; 53 : 2713-2718 EK III

[506] Saßmann H, Albrecht C, Busse-Widmann P et al. Psychometric properties of the German version of the Diabetes Eating Problem Survey-Revised: additional benefit of disease-specific screening in adolescents with Type 1 diabetes. Diabet Med 2015, EK IIb

[507] Sassmann H, Danne T, Landgraf $R$ et al. Jugendliche und junge Erwachsene mit Diabetes: Lebensqualität, Stoffwechseleinstellung und Zufriedenheit mit der Langzeitbetreuung von Teilnehmern des CAMP-D. Diabet Stoffw 2007; 2: 69, EK III

[508] Sassmann H, de HM, Danne T et al. Reducing stress and supporting positive relations in families of young children with type 1 diabetes: $\mathrm{A}$ randomized controlled study for evaluating the effects of the DELFIN parenting program. BMC Pediatr 2012; 12: 152, EK Ib

[509] Saßmann H, Lange K. Psychische Störungen bei Kindern und Jugendlichen mit Diabetes. In Petrak F, Herpertz S, (Hrsg). editors.: Handbuch der Psychodiabetologie. Springer; Berlin: 2013, EK IV

[510] Schatz DA, Bingley PJ. Update on major trials for the prevention of type 1 diabetes mellitus: The American Diabetes Prevention Trial (DPT-1) and the European Nicotinamide Diabetes Intervention Trial (ENDIT). J Pediatr Endocrinol Metab 2001; 14: (Suppl 1): 619-622, EK Ib

[511] Scherbaum W. Verlautbarung der Deutschen Diabetes-Gesellschaft zur Versorgung von Kindern und Jugendlichen. Diabet Inform 1998; 20: 23, EK IV

[512] Scheuing N, Bartus B, Berger G et al. Clinical characteristics and outcome of 467 patients with a clinically recognized eating disorder identified among 52215 patients with type 1 diabetes: A multicenter german/austrian study. Diabetes Care 2014; 37: 1581-1589, EK IIb 
[513] Schiaffini R, Patera PI, Bizzarri C et al. Basal insulin supplementation in Type 1 diabetic children: A long-term comparative observational study between continuous subcutaneous insulin infusion and glargine insulin. J Endocrinol Invest 2007; 30: 572-577, EK Ib

[514] Schlesinger DM, Holsclaw DS, Fyfe B. Generalized Atherosclerosis in an Adult with CF and Diabetes Mellitus. Eleventh Annual North American Cystic Fibrosis Conference 1997; 365: EK III

[515] Schmid K, Fink K, Holl RW et al. Predictors for future cystic fibrosis-related diabetes by oral glucose tolerance test. J Cyst Fibros 2014; 13: 80-85

[516] Schober E, Holl RW, Grabert M et al. Diabetes mellitus type 2 in childhood and adolescence in Germany and parts of Austria. Eur J Pediatr 2005; 164: 705-707, EK III

[517] Schober E, Rami B, Grabert M et al. Phenotypical aspects of Maturity-onset diabetes of the young (MODY diabetes) in comparison toType 2 diabetes mellitus (T2DM) in children and adolescents. Experience from a large multicenter data base. Diabet Med 2009; 26: 466-473

[518] Schoenle E], Schoenle D, Molinari L et al. Impaired intellectual development in children with Type I diabetes: Association with $\mathrm{HbA}(1 \mathrm{c})$, age at diagnosis and sex. Diabetologia 2002; 45: 108-114, EK III

[519] Schultz C], Konopelska-Bahu T, Dalton RN et al. Microalbuminuria prevalence varies with age, sex, and puberty in children with type 1 diabetes followed from diagnosis in a longitudinal study. Oxford Regional Prospective Study Group. Diabetes Care 1999; 22: 495-502, EK III

[520] Schultz C], Neil HA, Dalton RN et al. Blood pressure does not rise before the onset of microalbuminuria in children followed from diagnosis of type 1 diabetes. Oxford Regional Prospective Study Group. Diabetes Care 2001; 24: 555-560, EK III

[521] Schwab KO, Doerfer ], Marg W et al. Characterization of 33488 children and adolescents with type 1 diabetes based on the gender-specific increase of cardiovascular risk factors. Pediatr Diabetes 2010; 11: 357-363

[522] Schwartz DD, Cline VD, Axelrad ME et al. Feasibility, acceptability, and predictive validity of a psychosocial screening program for children and youth newly diagnosed with type 1 diabetes. Diabetes Care 2011; 34: 326-331, EK III

[523] Schwarzenberg S], Thomas W, Olsen TW et al. Microvascular complications in cystic fibrosis-related diabetes. Diabetes Care 2007; 30: 1056-1061, EK III

[524] Scott A, Whitcombe S, Bouchier D et al. Diabetes in children and young adults in Waikato Province, New Zealand:Outcomes of care. N Z Med J 2004; 117: U1219, EK III

[525] Scottish Intercollegiate Guidelines Network (SIGN). SIGN 50: A guideline developer's handbook. Quick reference guide. 2014

[526] Scottish Study Group for the Care of the Young Diabetic. Factors influencing glycemic control in young people with type 1 diabetes in Scotland: A population-based study (DIABAUD2). Diabetes Care 2001; 24: 239-244, EK Ila

[527] Scrimgeour L, Cobry E, McFann K et al. Improved glycemic control after long-term insulin pump use in pediatric patients with type 1 diabetes. Diabetes Technol Ther 2007; 9: 421-428, EK IIb-III

[528] Shah RP, Spruyt K, Kragie BC et al. Visuomotor performance in KCNJ11-related neonatal diabetes is impaired in children with DEND-associated mutations and may be improved by early treatment with sulfonylureas. Diabetes Care 2012; 35: 2086-2088

[529] Shepherd M, Hattersley AT. 'I don't feel like a diabetic any more': The impact of stopping insulin in patients with maturity onset diabetes of the young following genetic testing. Clin Med 2004; 4: 144-147
[530] Shichiri M, Kishikawa H, Ohkubo Y et al. Long-term results of the Kumamoto Study on optimal diabetes control in type 2 diabetic patients. Diabetes Care 2000; 23: (Suppl 2): B21-B29

[531] Shimazaki T, Kadowaki T, Ohyama Y et al. Hemoglobin A1c (HbA1c) predicts future drug treatment for diabetes mellitus: A follow-up study using routine clinical data in a Japanese university hospital. Transl Res 2007; 149: 196-204, EK II

[532] Shorer M, David R, Schoenberg-Taz M et al. Role of parenting style in achieving metabolic control in adolescents with type 1 diabetes. Diabetes Care 2011; 34: 1735-1737, EK III

[533] Sideravicite S, Gailiniene A, Visagurskiene $K$ et al. The effect of long-term swimming program on glycemia control in 14-19-year aged healthy girls and girls with type 1 diabetes mellitus. Medicina (Kaunas) 2006; 42: 513-518, EK Ilb

[534] Siebenhofer A, Plank J, Berghold A et al. Short acting insulin analogues versus regular human insulin in patients with diabetes mellitus. Cochrane Database Syst Rev 2006; CD003: 287, EK la

[535] Silverstein J, Klingensmith G, Copeland K et al. Care of children and adolescents with type 1 diabetes: A statement of the American Diabetes Association. Diabetes Care 2005; 28: 186-212, EK IV

[536] Silverstein J, Klingensmith G, Copeland K et al. Care of children and adolescents with type 1 diabetes: A statement of the American Diabetes Association. Diabetes Care 2005; 28: 186-212

[537] Simpson D, McCormack PL, Keating GM et al. Insulin lispro: A review of its use in the management of diabetes mellitus. Drugs 2007; 67: 407-434

[538] Skogsberg L, Fors H, Hanas R et al. Improved treatment satisfaction but no difference in metabolic control when using continuous subcutaneous insulin infusion vs. multiple daily injections in children at onset of type 1 diabetes mellitus. Pediatr Diabetes 2008; 9 : 472-479, EK1b

[539] Slama G, Haardt M], Jean-Joseph P et al. Sucrose taken during mixed meal has no additional hyperglycaemic action over isocaloric amounts of starch in well-controlled diabetics. Lancet 1984; 2: 122-125, EK Ib

[540] Slingerland AS, Hurkx W, Noordam K et al. Sulphonylurea therapy improves cognition in a patient with the V59M KCNJ11 mutation. Diabet Med 2008; 25: 277-281, EK III

[541] Slover RH, Welsh JB, Criego A et al. Effectiveness of sensor-augmented pump therapy in children and adolescents with type 1 diabetes in the STAR 3 study. Pediatr Diabetes 2012; 13: 6-11, EK Ib

[542] Smart CE, Annan F, Bruno LP et al. ISPAD -Clinical Practice Consensus Guidelines 2014. Nutritional management in children and adolescents with diabetes. Pediatr Diabetes 2014; 15: (Suppl 20): 135-153, EK IV

[543] Smith-Palmer J, Brandle M, Trevisan R et al. Assessment of the association between glycemic variability and diabetes-related complications in type 1 and type 2 diabetes. Diabetes Res Clin Pract 2014; 105: 273-284

[544] Sochett EB, Poon I, Balfe W et al. Ambulatory blood pressure monitoring in insulin-dependent diabetes mellitus adolescents with and without microalbuminuria. J Diabetes Complications 1998; 12: 18-23, EK IIa

[545] Soffer B, Zhang Z, Miller K et al. A doubleblind, placebo-controlled, dose-response study of the effectivenessand safety of lisinopril for children with hypertension. Am J Hypertens 2003; 16: 795-800, EK Ib

[546] Sood ED, Pendley JS, Delamater AM et al. Mother-father informant discrepancies regarding diabetes management: Associations with diabetes-specific family conflict and glycemic control. Health Psychol 2012; 31: 571-579, EK III

[547] Stachow R, Schiel R, Koch S et al. Effekte der stationären Rehabilitation von Kindern und Jugendlichen mit Diabetes mellitus Typ-1. Monatsschr Kinderheilkd 2013; 161: 727-734, EK III 
[548] Stachow R, Schiel R, Koch S et al. Langfristige Effekte der Rehabilitation für Kinder und Jugendliche mit Diabetes mellitus Typ 1. Diabetologie und Stoffwechsel 2013; 8: FV17, EK III

[549] Stachow R, Schultz A, Kurzinsky U et al. Anti-Streß-Training für Kinder und Jugendliche mit Diabetes während der stationären Rehabilitation. Kindheit Entwicklung 2001; 10: 226-239, EK III

[550] Stachow R, Wolf J, Kromeyer-Hauschild K et al. Übergewicht und Adipositas bei Kindern und Jugendlichen mit Diabetes mellitus Typ 1. Prävalenz und Einflussfaktoren. Monatsschr Kinderheilkd 2003; 149: 209-216, EK III

[551] Stahl A, Strassburger K, Lange K et al. Health-related quality of life among German youths with early-onset and long-duration type 1 diabetes. Diabetes Care 2012; 35: 1736-1742, EK IIB

[552] Stahl-Pehe A, Strassburger K, Castillo K et al. Quality of life in intensively treated youths with early-onset type 1 diabetes: $A$ population-based survey. Pediatr Diabetes 2014; 15: 436-443, EK IIB

[553] Stanger C, Ryan SR, Delhey LM et al. A multicomponent motivational intervention to improve adherence among adolescents with poorly controlled type 1 diabetes: A pilot study. J Pediatr Psychol 2013; 38: 629-637, EK III

[554] Stanik J, Gasperikova D, Paskova M et al. Prevalence of permanent neonatal diabetes in Slovakia and successful replacement of insulin with sulfonylurea therapy in $\mathrm{KCN} 11$ and $\mathrm{ABCC} 8$ mutation carriers. J Clin Endocrinol Metab 2007; 92: 1276-1282

[555] Stoy ], Edghill EL, Flanagan SE et al. Insulin gene mutations as a cause of permanent neonatal diabetes. Proc Natl Acad Sci USA 2007; 104: 15 040-15 044, EK III

[556] Stride A, Vaxillaire M, Tuomi T et al. The genetic abnormality in the beta cell determines the response to an oral glucose load. Diabetologia 2002; 45: 427-435, EK IIb

[557] Sullivan-Bolyai S, Bova C, Lee M et al. Mentoring fathers of children newly diagnosed with T1DM. MCN Am J Matern Child Nurs 2011; 36: 224-231, EK IIb

[558] Sullivan-Bolyai S, Deatrick J, Gruppuso P et al. Constant vigilance: Mothers' work parenting young children with type 1 diabetes. J Pediatr Nurs 2003; 18: 21-29, EK III

[559] Summers LK, Fielding BA, Bradshaw HA et al. Substituting dietary saturated fat with polyunsaturated fat changes abdominal fat distribution and improves insulin sensitivity. Diabetologia 2002; 45: 369-377, EK Ib

[560] Sundelin J, Forsander G, Mattson SE. Family-oriented support at the onset of diabetes mellitus: A comparison of two group conditions during 2 years following diagnosis. Acta Paediatr 1996; 85: 49-55, EK III

[561] Sundelin ], Forsander G, Mattson SE. Family-oriented support at the onset of diabetes mellitus: A comparison of two group conditions during 2 years following diagnosis. Acta Paediatr 1996; 85: 49-55, EK IIb

[562] Svensson J, Johannesen J, Mortensen HB et al. Improved metabolic outcome in a Danish diabetic paediatric population aged 0 - 18yr: Results from a nationwide continuous Registration. Pediatr Diabetes 2009; 10: 461-467, EK III

[563] Svoren BM, Butler D, Levine BS et al. Reducing acute adverse outcomes in youths with type 1 diabetes: A randomized, controlled trial. Pediatrics 2003; 112: 914-922, EK Ib

[564] Svoren BM, Volkening LK, Butler DA et al. Temporal trends in the treatment of pediatric type 1 diabetes and impact on acute outcomes. J Pediatr 2007; 150: 279-285, EK Ila

[565] Swift PG. Diabetes education. ISPADclinical practice consensus guidelines 2006-2007. Pediatr Diabetes 2007; 8: 103-109 EK IV

[566] Swift PG, Skinner TC, de Beaufort CE et al. Target setting in intensive insulin management is associated with metabolic control: The Hvidoere childhood diabetes study group centre differences study. 2005; Pediatr Diabetes 2010; 11: 271-278, EK III
[567] Taha D, Umpaichitra V, Banerji MA et al. Type 2 diabetes mellitus in African-American adolescents: Impaired beta- cell function in the face of severe insulin resistance. J Pediatr Endocrinol Metab 2006; 19: 135-142, EK IIb

[568] Takii M, Uchigata Y, Komaki G et al. An integrated inpatient therapy for type 1 diabetic females with bulimia nervosa: A 3-year follow-up study. J Psychosom Res 2003; 55: 349-356, EK III

[569] Tansey M], Tsalikian E, Beck RW et al. The effects of aerobic exercise on glucose and counterregulatory hormone concentrations in children with type 1 diabetes. Diabetes Care 2006; 29: 20-25, EK Ib

[570] Temple IK, Gardner RJ, Mackay D] et al. Transient neonatal diabetes: Widening the understanding of the etiopathogenesis of diabetes. Diabetes 2000; 49: 1359-1366, EK III

[571] Temple IK, Shield JP. Transient neonatal diabetes, a disorder of imprinting. J Med Genet 2002; 39: 872-875, EK IV

[572] Thalange N, Deeb L, lotova $V$ et al. Insulin degludec in combination with bolus insulin aspart is safe and effective in children and adolescents with type 1 diabetes. Pediatr Diabetes 2015; 16: 164-176, EK Ib

[573] Thisted H, Johnsen SP, Rungby J. An update on the longacting insulin analogue glargine. Basic Clin Pharmacol Toxicol 2006; 99: 1-11, EK la

[574] Thompson S], Auslander WF, White NH. Comparison of single-mother and two-parent families on metabolic control of children with diabetes. Diabetes Care 2001; 24: 234-238, EK Ila

[575] Thomsen C, Storm H, Holst J] et al. Differential effects of saturated and monounsaturated fats on postprandial lipemia and glucagon-like peptide 1 responses in patients with type 2 diabetes. Am J Clin Nutr 2003; 77: 605-611, EK Ib

[576] Thorpe CT, Fahey LE, Johnson $\mathrm{H}$ et al. Facilitating healthy coping in patients with diabetes: A systematic review. Diabetes Educ 2013; 39: 33-52, EK la

[577] Thurber BW, Carmody D, Tadie EC et al. Age at the time of sulfonylurea initiation influences treatment outcomes in KCNJ11related neonatal diabetes. Diabetologia 2015; 58: 1430-1435, EK III

[578] Tiberg I, Katarina SC, Carlsson A et al. Children diagnosed with type 1 diabetes: A randomized controlled trial comparing hospital versus home-based care. Acta Paediatr 2012; 101: 1069-1073, EK Ib

[579] Toeller M. (nach Mann et al. 2004) Evidenz-basierte Ernährungsempfehlungen zur Behandlung und Prävention des Diabetes mellitus. Diabet Stoffw 2005; 14: 75-94, EK la-IV

[580] Toni S, Reali MF, Barni F et al. Managing insulin therapy during exercise in type 1 diabetes mellitus. Acta Biomed 2006; 77: (Suppl 1): 34-40, EK IIa-III

[581] Triolo TM, Armstrong TK, McFann K et al. Additional autoimmune disease found in $33 \%$ of patients at type 1 diabetes onset. Diabetes Care 2011; 34: 1211-1213, EK III

[582] Tsalikian E, Kollman C, Tamborlane WB et al. Prevention of hypoglycemia during exercise in children with type 1 diabetes by suspending basal insulin. Diabetes Care 2006; 29: 2200-2204, EK Ib

[583] Tsiouli E, Alexopoulos EC, Stefanaki C et al. Effects of diabetes-related family stress on glycemic control in young patients with type 1 diabetes: Systematic review. Can Fam Physician 2013; 59: 143-149, EK Ib

[584] Tubiana-Rufi N, Coutant R, Bloch J et al. Special management of insulin lispro in continuous subcutaneous insulin infusion in young diabetic children: A randomized cross-over study. HormRes 2004; 62: 265-271, EK Ib

[585] Tuomilehto J, Lindstrom J, Eriksson JG et al. Prevention of type 2 diabetesmellitus by changes in lifestyle among subjects with impaired glucose tolerance. N Engl J Med 2001; 344: 1343-1350, EK Ib

[586] Tupola S, Komulainen J, Jaaskelainen J et al. Post-prandial insulin lispro vs. human regular insulin in prepubertal children with Type 1 diabetes mellitus. Diabet Med 2001; 18: 654-658, EK Ib 
[587] UK Prospective Diabetes Study (UKPDS) Group. Effect of intensive blood-glucose control with metformin on complications in overweight patients with type 2 diabetes (UKPDS 34). UK Prospective Diabetes Study (UKPDS) Group. Lancet 1998; 352: 854-865, EK Ib

[588] UK Prospective Diabetes Study (UKPDS) Group. Intensive bloodglucose control with sulphonylureas or insulin compared with conventional treatment and risk of complications in patients with type 2 diabetes (UKPDS 33). UK Prospective Diabetes Study (UKPDS) Group. Lancet 1998; 352: 837-853, EK Ib

[589] UK Prospective Diabetes Study (UKPDS) Group. Tight blood pressure control and risk of macrovascular and microvascular complications in type 2 diabetes: UKPDS 38. BMJ 1998; 317: 703-713, EK Ib

[590] Vaarala O, Klemetti P, Juhela $S$ et al. Effect of coincident enterovirus infection and cows'milk exposure on immunisation to insulin in early infancy. Diabetologia 2002; 45: 531-534, EK Ib

[591] Valenzuela JM, Patino AM, McCullough J et al. Insulin pump therapy and health-related quality of life in children and adolescents with type 1 diabetes. J Pediatr Psychol 2006; 31: 650-660, EK IIb

[592] van den Berg JM, Morton AM, Kok SW et al. Microvascular complications in patients with cystic fibrosis-related diabetes (CFRD). J Cyst Fibros 2008; 7: 515-519, EK III

[593] Vessby B, Unsitupa M, Hermansen K et al. Substituting dietary saturated for monounsaturated fat impairs insulin sensitivity in healthy men and women: The KANWU Study. Diabetologia 2001; 44: 312-319, EK Ib

[594] Viklund G, Ortqvist E, Wikblad K. Assessment of an empowerment education programme. A randomized study in teenagers with diabetes. Diabet Med 2007; 24: 550-556, EK Ib

[595] Viner RM, Christie D, Taylor V et al. Motivational/solutionfocused intervention improves $\mathrm{HbA} 1 \mathrm{C}$ in adolescents with Type 1 diabetes: $\mathrm{A}$ pilot study. Diabet Med 2003; 20: 739-742, EK III

[596] von Sengbusch S, Muller-Godeffroy E, Hager S et al. Mobile diabetes education and care: Intervention for children and young people with Type 1 diabetes in rural areas of northern Germany. Diabet Med 2006; 23: 122-127, EK IIb

[597] Wabitsch M, Hertrampf M, Mayer $\mathrm{H}$ et al. Glucosetoleranz und Insulinresistenz bei Kindern und Jugendlichen mit Adipositas. Diabet Stoffw 2002; Suppl 10: 34, EK III

[598] Wagner VM, Grabert M, Holl RW. Severe hypoglycaemia, metabolic control and diabetes management in children with type 1 diabetes in the decade after the Diabetes Control and Complications Trial - a large-scale multicentre study. Eur J Pediatr 2005; 164: 73-79 IIb-III

[599] Wagner VM, Kremke B, Hiort O et al. Transition from insulin to sulfonylurea in a child with diabetes due to a mutation in KCNJ11 encoding Kir6.2-initial and long-term response to sulfonylurea therapy. Eur J Pediatr 2009; 168: 359-361

[600] Waldron S, Rurik I, Madacsy L et al. Good practice recommendations on paediatric training programmes for health care professionals in the EU. Pediatr Diabetes 2012; 13: (Suppl 16): 29-38, EK IV

[601] Wambach JA, Marshall BA, Koster JC et al. Successful sulfonylurea treatment of an insulin-naive neonate with diabetes mellitus due to a KCNJ11 mutation. Pediatr Diabetes 2010; 11: 286-288

[602] Wang YC, Stewart SM, Mackenzie M et al. A randomized controlled trial comparing motivational interviewing in education to structured diabetes education in teens with type 1 diabetes. Diabetes Care 2010; 33: 1741-1743, EK Ib

[603] Warncke K, Frohlich-Reiterer EE, Thon A et al. Polyendocrinopathy in children, adolescents, and young adults with type 1 diabetes: $\mathrm{A}$ multicenter analysis of 28671 patients from the German/Austrian DPVWiss database. Diabetes Care 2010; 33: 2010-2012, EK III

[604] Watts GF, Gregory L, Naoumova R et al. Nutrient intake in insulindependent diabetic patients with incipient nephropathy. Eur J Clin Nutr 1988; 42: 697-702, EK III
[605] Weinzimer SA, Swan KL, Sikes KA et al. Emerging evidence for the use of insulin pump therapy in infants, toddlers, and preschool-aged children with type 1 diabetes. Pediatr Diabetes 2006; 7: (Suppl 4): 15-19 EK la-III

[606] Weissberg-Benchell J, Glasgow AM, Tynan WD et al. Adolescent diabetes management and mismanagement. Diabet Care 1995; 18: 77-82, EK III

[607] Weitzel D, Obermann B, Rogge R. Tagesklinische Ersteinstellung es kindlichen und jugendlichen IDDM. Diabet Stoffw 1997; 6: 110, EK IV

[608] Wells T, Frame V, Soffer B et al. A double-blind, placebo-controlled, dose-response study of the effectiveness and safety of enalapril for children with hypertension. J Clin Pharmacol 2002; 42: 870-880, EK Ib

[609] White NH, Cleary PADahmsW et al. Beneficial effects of intensive therapy of diabetes during adolescence: Outcomes after the conclusion of the Diabetes Control and Complications Trial (DCCT). J Pediatr 2001; 139: 804-812, EK Ib

[610] White NH, Sun W, Cleary PA et al. Prolonged effect of intensive therapy on the risk of retinopathy complications in patients with type 1 diabetes mellitus: 10 years after the Diabetes Control and Complications Trial. Arch Ophthalmol 2008; 126: 1707-1715, EK Ib

[611] Whittemore R, Jaser S, Chao A et al. Psychological experience of parents of children with type 1 diabetes: A systematic mixed-studies review. Diabetes Educ 2012; 38: 562-579, EK Ib

[612] Wiebe DJ, Berg CA, Korbel C et al. Children's appraisals of maternal involvement in coping with diabetes: Enhancing our understanding of adherence, metabolic control, and quality of life across adolescence. J Pediatr Psychol 2005; 30: 167-178, EK III

[613] Wisting L, Froisland DH, Skrivarhaug T et al. Disturbed eating behavior and omission of insulin in adolescents receiving intensified insulin treatment: A nationwide population-based study. Diabetes Care 2013; 36: 3382-3387, EK III

[614] Wolfsdorf J, Craig ME, Daneman D et al. Diabetic ketoacidosis. Pediatr Diabetes 2007; 8: 28-43, EK IV

[615] Wolfsdorf JI, Allgrove J, Craig ME et al. ISPADClinical Practice Consensus Guidelines 2014. Diabetic ketoacidosis and hyperglycemic hyperosmolar state. Pediatr Diabetes 2014; 15: (Suppl 20): 154-179, EK IV

[616] Wood JR, Moreland EC, Volkening LK et al. Durability of insulin pump use in pediatric patients with type 1 diabetes. Diabetes Care 2006; 29: 2355-2360, EK IIb-III

[617] World Health Organinsation (WHO). Technical Report Series 916. Diet, Nutrition and the Prevention of Chronic Diseases. Report of a Joint FAO/WHO Expert Consultation, WHO; Geneva: 2003 EK IV

[618] Wühl E, Witte K, Soergel M et al. Distribution of 24-h ambulatory blood pressure in children: Normalized reference values and role of body dimensions. J Hypertens 2002; 20: 1995-2007, EK Ilb

[619] Wysocki T, Greco P, Harris MA et al. Behavior therapy for families of adolescents with diabetes: Maintenance of treatment effects. Diabetes Care 2001; 24: 441-446, EK Ila

[620] Wysocki T, Harris MA, Buckloh LM et al. Randomized trial of behavioral family systems therapy for diabetes: Maintenance of effects on diabetes outcomes in adolescents. Diabetes Care 2007; 30 555-360, EK Ib

[621] Wysocki T, Harris MA, Buckloh LM et al. Randomized, controlled trial of Behavioral Family Systems Therapy for Diabetes: Maintenance and generalization of effects on parent-adolescent communication. Behav Ther 2008; 39: 33-46, EK Ib

[622] Wysocki T, HarrisMA Greco P et al. Randomized, controlled trial of behavior therapy for families of adolescents with insulin- dependent diabetes mellitus. J Pediatr Psychol 2000; 25: 23-33, EK Ib

[623] Wysocki T, Lochrie A, Antal $\mathrm{H}$ et al. Youth and parent knowledge and communication about major complications of type 1 diabetes: Associations with diabetes outcomes. Diabetes Care 2011; 34: 1701-1705, EK Ib 
[624] Wysocki T, Lochrie A, Antal $\mathrm{H}$ et al. Youth and parent knowledge and communication about major complications of type 1 diabetes: Associations with diabetes outcomes. Diabetes Care 2011; 34: 1701-1705, EK III

[625] Wysocki T, Taylor A, Hough BS et al. Deviation from developmentally appropriate selfcare autonomy. Association with diabetes outcomes. Diabet Care 1997; 19: 121-125, EK IIb

[626] Yokota Y, Kikuchi N, Matsuura N. Screening for diabetes by urine glucose testing at school in Japan. Pediatr Diabetes 2004; 5 : 212-218, EK III

[627] Young V, Eiser C, Johnson B et al. Eating problems in adolescents with Type 1 diabetes: A systematic review with meta-analysis. Diabet Med 2013; 30: 189-198, EK la

[628] Zeitler P, Fu J, Tandon $\mathrm{N}$ et al. ISPADClinical Practice Consensus Guidelines 2014. Type 2 diabetes in the child and adolescent. Pediatr Diabetes 2014; 15: 26-46, EK IV
[629] Zenlea IS, Mednick L, Rein J et al. Routine behavioral and mental health screening in young children with type 1 diabetes mellitus. Pediatr Diabetes 2014; 15: 384-388, EK III

[630] Ziegler AG, Schmid S, Huber D et al. Early infant feeding and risk of developing type 1 diabetes-associated autoantibodies. JAMA 2003; 290: 1721-1728, EK III

[631] Ziegler R, Heidtmann B, Hilgard D et al. Frequency of SMBG correlates with $\mathrm{HbA} 1 \mathrm{c}$ and acute complications in children and adolescents with type 1 diabetes. Pediatr Diabetes 2011; 12: 11-17, EK III

[632] Zung A, Glaser B, Nimri R et al. Glibenclamide treatment in permanent neonatal diabetes mellitus due to an activating mutation in Kir6.2. J Clin Endocrinol Metab 2004; 89: 5504-5507, EK III 